Prepared in cooperation with the Federal Emergency Management Agency, the U.S. Army Corps of Engineers, and the U.S. Forest Service

\title{
Regional Skew for California, and Flood Frequency for Selected Sites in the Sacramento-San Joaquin River Basin, Based on Data through Water Year 2006
}

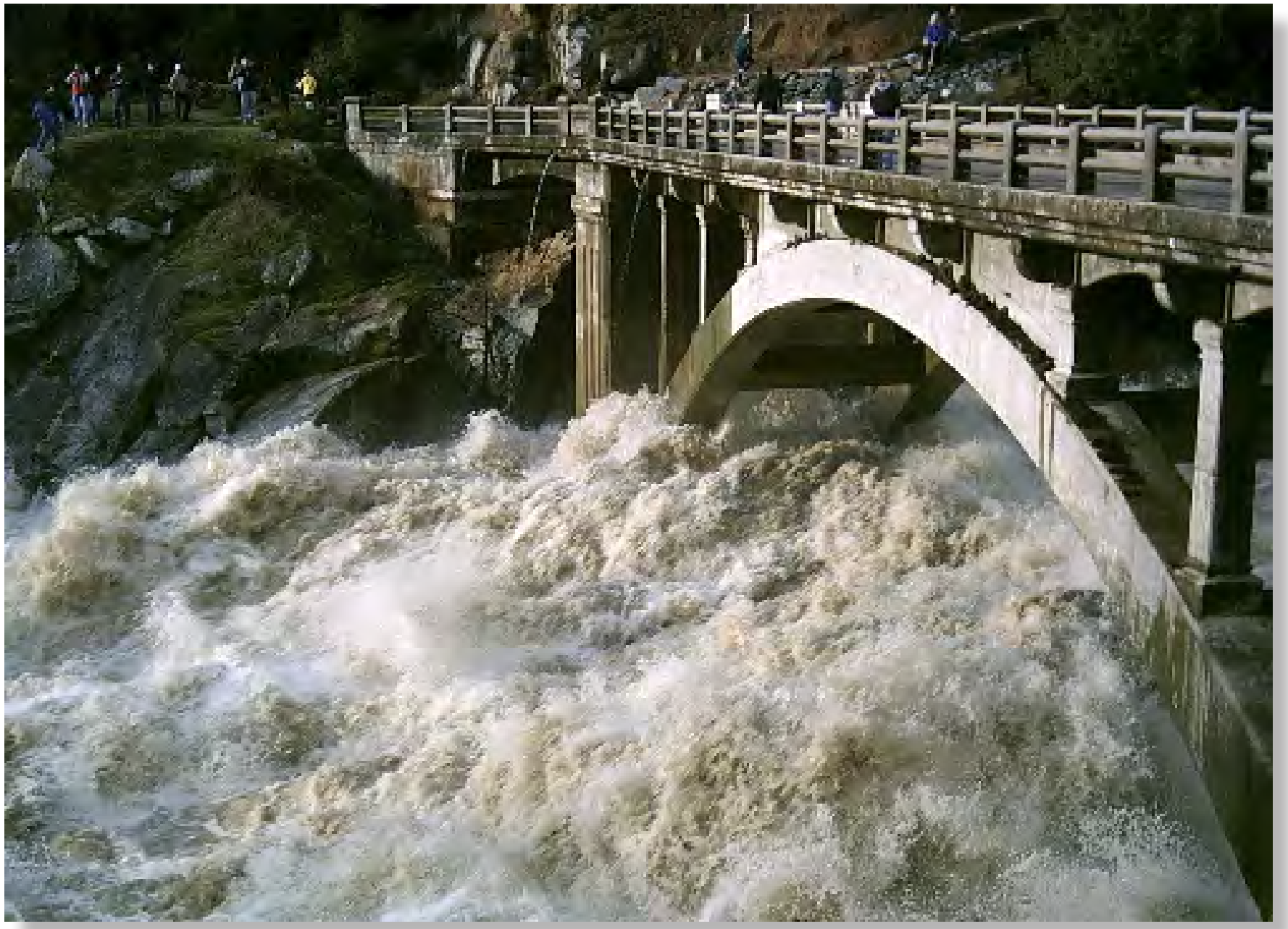

Scientific Investigations Report 2010-5260 
Cover: Photogrph showing flooding on the South Yuba River on January 1, 2006 at the Old Highway 49 crossing near Nevada City, California. Photograph was taken by lan 0'Halloran. 


\section{Regional Skew for California, and Flood \\ Frequency for Selected Sites in the \\ Sacramento-San Joaquin River Basin, Based on Data through Water Year 2006}

By Charles Parrett, U.S. Geological Survey, Andrea Veilleux and J.R. Stedinger,

Cornell University; N. A. Barth, Donna L. Knifong, and J.C. Ferris, U.S. Geological

Survey

Prepared in cooperation with Federal Emergency Management Agency,

U.S. Army Corps of Engineers, and U.S. Forest Service

Scientific Investigations Report 2010-5260 


\title{
U.S. Department of the Interior \\ KEN SALAZAR, Secretary \\ U.S. Geological Survey \\ Marcia K. McNutt, Director
}

\author{
U.S. Geological Survey, Reston, Virginia: 2011
}

For more information on the USGS - the Federal source for science about the Earth, its natural and living resources, natural hazards, and the environment, visit http://www.usgs.gov or call 1-888-ASK-USGS.

For an overview of USGS information products, including maps, imagery, and publications, visit http://www.usgs.gov/pubprod

To order this and other USGS information products, visit http://store.usgs.gov

Any use of trade, product, or firm names is for descriptive purposes only and does not imply endorsement by the U.S. Government.

Although this report is in the public domain, permission must be secured from the individual copyright owners to reproduce any copyrighted materials contained within this report.

Suggested citation:

Parrett, C., Veilleux, A., Stedinger, J.R., Barth, N.A., Knifong, D.L., and Ferris, J.C., 2011, Regional skew for California, and flood frequency for selected sites in the Sacramento-San Joaquin River Basin, based on data through water year 2006: U.S. Geological Survey Scientific Investigations Report 2010-5260, 94 p. 


\section{Contents}

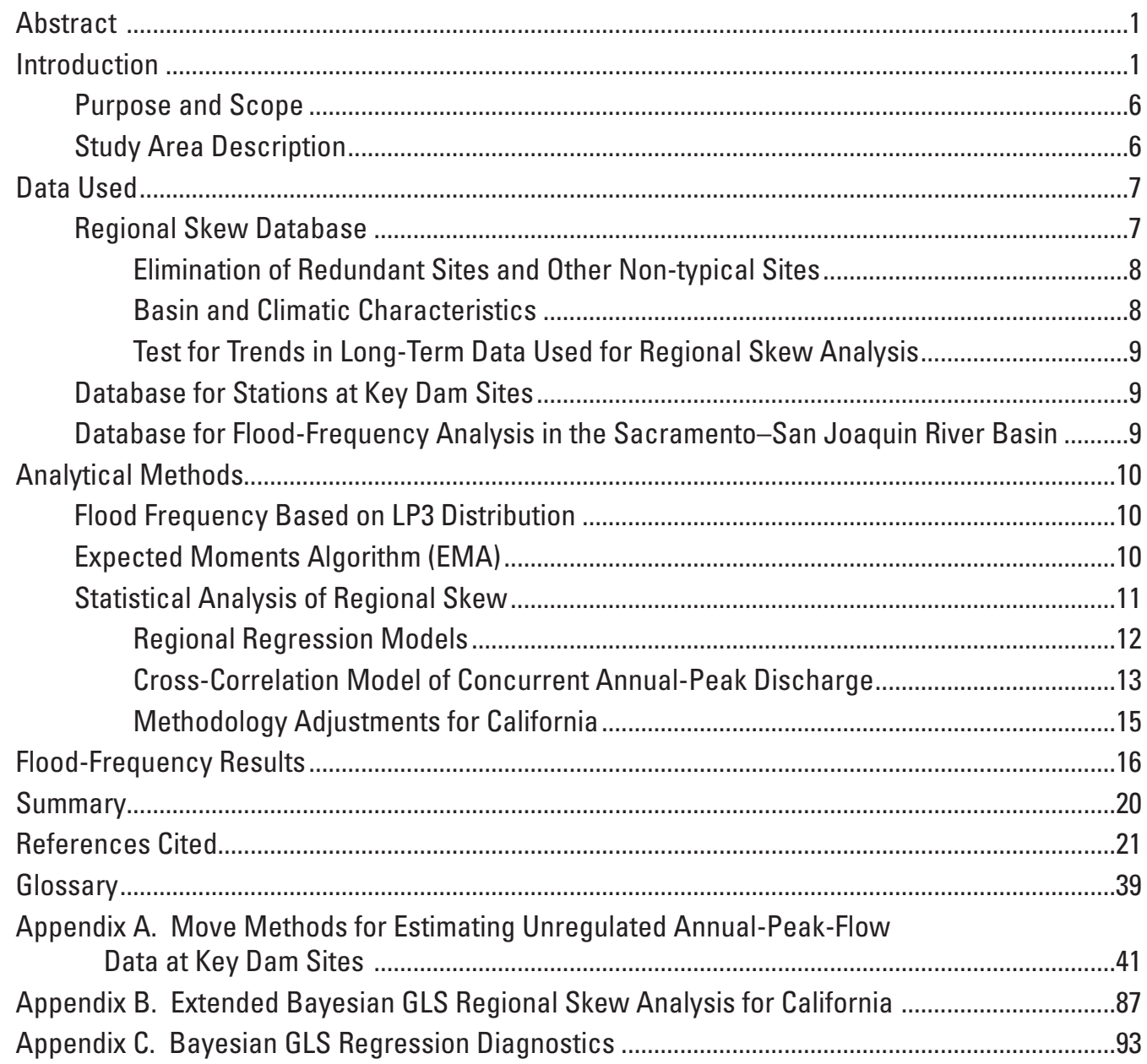




\section{Figures}

Figure 1. California map showing stations in northern, central, and southern Californiaselected for regional skew analysis outside the desert exclusion area and flood-frequency analysis in the Sacramento-San Joaquin River Basin, California

Figure 2. Graph showing relation between the average timing of peak discharge and mean basin elevation for 158 sites used for regional skew analysis in California ... 7

Figure 3. Graph showing relation between the Fisher $Z$ transform (Z) of logs of annual-peak discharge and distance between basin centroids for 159 station-pairs in California

Figure 4. Graph showing relation between the cross-correlation of logs of annual-peak discharge and the distance between basin centroids based on data from 159 station-pairs in California and 1,317 station-pairs in the Southeastern United States

Figure 5. Graph showing histogram of relative frequency of calculated cross-correlation values in California and in the Southeastern United States

Figure 6. Graph showing relations between the unbiased at-site skew and the mean basin elevation for 158 sites in California 16

Figure 7. Graph showing flood-frequency curves for Saratoga Creek, California, based on 73 years of recorded data with no censoring of annual-peak discharge 17

Figure 8. Graph showing flood-frequency curves for Kingsbury Creek, California, based on 11 years of recorded data with no censoring of annual-peak discharge

Figure 9. Graph showing flood-frequency curves for West Walker River, California, based on 81 years of data recorded during an historical period of 106 years with a perception threshold discharge equal to the largest discharge during the 81-year record period

Figure 10. Graph showing flood-frequency curves for Cantua Creek, California, based on 49 years of recorded data with all peaks smaller than the 50 -percent exceedance probability censored as low outliers.

\section{Tables}

Table 1. Streamflow-gaging stations and statistical data used to analyze regional skew in California and to determine flood frequency for the Sacramento-San Joaquin River Basin, California

Table 2. Basin characteristics for analyzing regional skew in California $\ldots \ldots \ldots \ldots \ldots \ldots 23$

Table 3. Basin characteristics for sites used in the regional skew analysis, California ..... 24

Table 4. Results of trend tests for annual peak discharge at selected sites in California ... 24

Table 5. Key dam sites and drainage areas, periods of estimated unregulated annual-maximum-daily discharge, and periods of concurrent unregulated annual-maximum-daily and peak-discharge data ............................ 25

Table 6. Unregulated, annual-maximum-daily discharge for key dam sites, California ..... 26

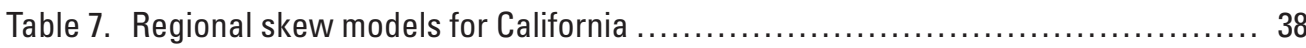

Table 8. Average regional skew, variance of prediction (VPnew) and equivalent record length (ERL) for nonlinear regional skew model NL-Elev for various values of mean basin elevation (ELEV), California 


\section{Conversion Factors, Datums, and Acronyms}

Inch/Pound to SI

\begin{tabular}{lcl}
\hline & Bultiply & \multicolumn{1}{c}{ To obtain } \\
\hline inch (in.) & Length & \\
inch (in.) & 2.54 & centimeter $(\mathrm{cm})$ \\
foot (ft) & 25.4 & millimeter $(\mathrm{mm})$ \\
mile (mi) & 0.3048 & meter $(\mathrm{m})$ \\
& 1.609 & kilometer $(\mathrm{km})$ \\
\hline square mile $\left(\mathrm{mi}^{2}\right)$ & Area & \\
square mile $\left(\mathrm{mi}^{2}\right)$ & 259.0 & hectare $(\mathrm{ha})$ \\
& 2.590 & square kilometer $\left(\mathrm{km}^{2}\right)$ \\
\hline cubic foot per second $(\mathrm{ft} / \mathrm{s})$ & Flow rate & \\
\hline
\end{tabular}

SI to Inch/Pound

\begin{tabular}{lll}
\hline \multicolumn{1}{c}{ Multiply } & By & \multicolumn{1}{c}{ To obtain } \\
\hline centimeter $(\mathrm{cm})$ & Length & \\
millimeter $(\mathrm{mm})$ & 0.3937 & inch (in.) \\
meter $(\mathrm{m})$ & 0.03937 & inch (in.) \\
kilometer $(\mathrm{km})$ & 3.281 & foot $(\mathrm{ft})$ \\
\hline & 0.6214 & mile (mi) \\
\hline square centimeter $\left(\mathrm{cm}^{2}\right)$ & Area & \\
square meter $\left(\mathrm{m}^{2}\right)$ & 0.001076 & square foot $\left(\mathrm{ft}^{2}\right)$ \\
square centimeter $\left(\mathrm{cm}^{2}\right)$ & 10.76 & square foot $\left(\mathrm{ft}^{2}\right)$ \\
square kilometer $\left(\mathrm{km}^{2}\right)$ & 0.1550 & square inch $\left(\mathrm{ft}^{2}\right)$ \\
\hline & 0.3861 & square mile $\left(\mathrm{mi}^{2}\right)$ \\
\hline square centimeter $\left(\mathrm{cm}^{2}\right)$ & Volume & \\
square meter $\left(\mathrm{m}^{2}\right)$ & 0.03531 & cubic foot $\left(\mathrm{ft}^{3}\right)$ \\
square centimeter $\left(\mathrm{cm}^{2}\right)$ & 35.31 & cubic foot $\left(\mathrm{ft}^{3}\right)$ \\
square kilometer $\left(\mathrm{km}^{2}\right)$ & 1.308 & cubic yard $\left(\mathrm{yd}^{3}\right)$ \\
\hline & 0.2399 & cubic mile $\left(\mathrm{mi}^{3}\right)$ \\
\hline cubic meter per second $\left(\mathrm{m}^{3} / \mathrm{s}\right)$ & Flow rate & \\
\hline
\end{tabular}

Temperature in degrees Celsius $\left({ }^{\circ} \mathrm{C}\right)$ may be converted to degrees Fahrenheit $\left({ }^{\circ} \mathrm{F}\right)$ as follows:

$$
{ }^{\circ} \mathrm{F}=\left(1.8 \times{ }^{\circ} \mathrm{C}\right)+32
$$

Temperature in degrees Fahrenheit $\left({ }^{\circ} \mathrm{F}\right)$ may be converted to degrees Celsius $\left({ }^{\circ} \mathrm{C}\right)$ as follows:

$$
{ }^{\circ} \mathrm{C}=\left({ }^{\circ} \mathrm{F}-32\right) / 1.8
$$




\section{Conversion Factors, Datums, and Acronyms—Continued}

\section{Datums}

Vertical coordinate information is referenced to the North American Vertical Datum of 1988 (NAVD 88).

Horizontal coordinate information is referenced to the North American Datum of 1983 (NAD 83).

Elevation refers to distance above or below NAVD 88.

Water year is the 12-month period, 0 ctober 1 through September 30 , and is designated by the calendar year in which it ends. Thus, the water year ending September 30, 2001 is called "water year 2001."

Acronyms

ACOE

ANOVA

ASEV

AVP

B-GLS

B-WLS

DAR

DWR

ELEV

EMA

ERL

EVR

FEMA

GIS

GLS

LP3

MBV

MHDP

MM-WLS

MOVE.1

MOVE.2

MOVE.3

MOVE.4

MSE

ND

NHDPlus

NLCD

NL-Elev

NWIS

PRISM

USGS

VP

WLS
Army Corps of Engineers

analysis of variance

average sampling error variance

average variance of prediction

Bayesian generalized least squares

Bayesian weighted least squares

drainage area ratio

Department of Water Resources

mean basin elevation

expected moments algorithm

effective record length

error variance ratio

Federal Emergency Management Agency

geographic information system

generalized least squares

log Pearson Type 3

misrepresentation of the beta variance

Multi-Hazards Demonstration Project

method-of-moments weighted least squares

maintenance of variance extension type I

maintenance of variance extension type II

maintenance of variance extension 3

maintenance of variance extension 4

mean square error

normalized distance

National Hydrologic Dataset

National Land-Cover Dataset

nonlinear regional skew model

National Water Information System

Parameter-Elevation Regressions on Independent Slopes Model

U.S. Geological Survey

variance of prediction

weighted least squares 


\title{
Regional Skew for California and Flood Frequency for Selected Sites in the Sacramento-San Joaquin River Basin Based on Data through Water Year 2006
}

\author{
By Charles Parrett' ${ }^{1}$, Andrea Veilleux², J.R. Stedinger ${ }^{2}$, N. A. Barth ${ }^{1}$, Donna L. Knifong ${ }^{1}$, and J.C. Ferris ${ }^{1}$
}

\section{Abstract}

Improved flood-frequency information is important throughout California in general and in the Sacramento-San Joaquin River Basin in particular, because of an extensive network of flood-control levees and the risk of catastrophic flooding. A key first step in updating flood-frequency information is determining regional skew. A Bayesian generalized least squares (GLS) regression method was used to derive a regional-skew model based on annual peakdischarge data for 158 long-term (30 or more years of record) stations throughout most of California. The desert areas in southeastern California had too few long-term stations to reliably determine regional skew for that hydrologically distinct region; therefore, the desert areas were excluded from the regional skew analysis for California. Of the 158 long-term stations used to determine regional skew, 145 have minimally regulated annual-peak discharges, and 13 stations are dam sites for which unregulated peak discharges were estimated from unregulated daily maximum discharge data furnished by the U.S. Army Corp of Engineers. Station skew was determined by using an expected moments algorithm (EMA) program for fitting the Pearson Type 3 flood-frequency distribution to the logarithms of annual peak-discharge data.

The Bayesian GLS regression method previously developed was modified because of the large cross correlations among concurrent recorded peak discharges in California and the use of censored data and historical flood information with the new expected moments algorithm. In particular, to properly account for these cross-correlation problems and develop a suitable regression model and regression diagnostics, a combination of Bayesian weighted least squares and generalized least squares regression was adopted. This new methodology identified a nonlinear function relating regional skew to mean basin elevation. The regional skew

\footnotetext{
${ }^{1}$ U.S. Geological Survey, California Water Science Center, Placer Hall, 6000 J Street, Sacramento, California 95819

${ }^{2}$ Cornell University, School of Civil \& Environmental Engineering, 220 Hollister Hall, Ithaca, New York 14853
}

values ranged from -0.62 for a mean basin elevation of zero to 0.61 for a mean basin elevation of 11,000 feet. This relation between skew and elevation reflects the interaction of snow with rain, which increases with increased elevation. The equivalent record length for the new regional skew ranges from 52 to 65 years of record, depending upon mean basin elevation. The old regional skew map in Bulletin 17B, published by the Hydrology Subcommittee of the Interagency Advisory Committee on Water Data (1982), reported an equivalent record length of only 17 years.

The newly developed regional skew relation for California was used to update flood frequency for the 158 sites used in the regional skew analysis as well as 206 selected sites in the Sacramento-San Joaquin River Basin. For these sites, annual-peak discharges having recurrence intervals of $2,5,10,25,50,100,200$, and 500 years were determined on the basis of data through water year 2006. The expected moments algorithm was used for determining the magnitude and frequency of floods at gaged sites by using regional skew values and using the basic approach outlined in Bulletin 17B.

\section{Introduction}

Reliable estimates of peak discharge for various exceedance frequencies, commonly referred to as floodfrequency estimates, are needed by engineers, land-use planners, resource managers, and scientists. Flood-frequency information is required for flood-hazard assessment, safe and cost-effective design of water conveyance and transportation structures in or near streams, and floodplain delineation for flood insurance and land-use management. Water Science Centers within the U.S. Geological Survey (USGS) commonly provide updated flood-frequency estimates for streamflowgaging stations every 5 to 10 years based on cooperator needs and funding availability. The USGS provides methods for estimating flood-frequency at ungaged sites also. State-wide updates of flood-frequency at gaged sites and methods for estimation at ungaged sites in California were last completed 
in 1977 (Waananen and Crippen, 1977). The additional 30 years of flow record and new analytical methods together with an increasing need for essential levee improvements and flood-frequency information due to increased population fully justify updating the frequency information. Accordingly, the USGS, in cooperation with the U.S. Forest Service, Federal Emergency Management Agency (FEMA), and the USGS Multi-Hazards Demonstration Project (MHDP), initiated a regional flood-frequency study for California in 2008. This comprehensive study consists of (1) updating flood-frequency information for all suitable USGS gages that have minimally regulated peak-discharge records for at least 10 years, (2) developing methodologies for estimating flood-frequency information for ungaged sites in California, and (3) implementing a StreamStats (Ries and others, 2008) application for California. The StreamStats webpage application will initially provide basin and climatic characteristics data and flood-estimation equations based on two earlier flood-frequency reports for California (Waananen and Crippen, 1977; Thomas and others, 1997). As new flood-estimation equations are developed for use throughout California, they will be incorporated into the California StreamStats web page.

Bulletin 17B of the Hydrology Subcommittee of the Interagency Advisory Committee on Water Data (1982), hereinafter referred to as Bulletin 17B, recommends that the $\log$ Pearson Type 3 probability distribution be used to estimate flood frequency at gaged sites. A key to accurately fitting this distribution to recorded flood data is to reliably estimate the shape or skewness of the distribution, which is often significantly affected by the presence of very small or very large discharges in the record (outliers). Accordingly, Bulletin 17B also recommends that at-site skew calculated from recorded data be weighted with regional skew determined from pooled data at nearby long-term sites. Recent studies described by Reis and others (2005), Weaver and others (2009), Feaster and others (2009), and Gotvald and others (2009) have shown that Bayesian generalized least squares (GLS) regression provides an effective statistical framework for estimating regional skew. The regional skewness estimators are more accurate and have smaller mean square errors than those attributed to the Bulletin 17B skew map. Thus, an important contribution of this study was the development of new regional skew relations for California using extensions to Bayesian GLS regression. A key first step in the regional skew analysis was determining at-site (station) skew values for selected long-term (30 or more years of peak-discharge record) stations. The desert areas in southeastern California had too few long-term stations to determine regional skew with reasonable reliability for that hydrologically distinct region, so the desert region shown on figure 1 was excluded from the regional skew analysis for California. Station skew was determined using a new expected moment algorithm (EMA) program for fitting the Pearson Type 3 flood-frequency distribution to the logarithms of annual peak-flow data developed by the USGS (Cohn and others, 1997, 2001; Griffis and others, 2004).

An area of particular interest and need for updated floodfrequency data is the combined Sacramento and San Joaquin River Basin in central California. Large population centers, including the capital city of Sacramento, Stockton, Modesto, and Fresno, and widespread suburban development between the cities are at least partially located on floodplains of the Sacramento and San Joaquin Rivers and their tributaries. An extensive network of levees provides flood protection, but many of the levees are in need of upgrades and rehabilitation. To ensure that levee upgrades are designed in accordance with the latest and most complete hydrologic information, the U.S. Army Corps of Engineers (ACOE), in cooperation with the California Department of Water Resources (DWR), has begun a hydrologic analysis of floodplain areas protected by the Federal-State levee system within the Sacramento and San Joaquin combined drainage basin. As part of their hydrologic analysis, the ACOE requires flood-frequency information for simulated unregulated peak discharges at stream sites where peak discharges are partially or completely regulated.

Because the USGS and ACOE share a common interest and need for updated flood-frequency information in central California, both agencies developed a secondary cooperative flood-frequency program. This program tasked the USGS with developing a method for estimating unregulated annual-peak discharge at 16 selected key dam sites in the Sacramento-San Joaquin River Basin and using the estimated annual-peak discharges at the sites as part of the regional skew analysis already begun by the USGS for all of California outside the southeastern desert region. Results from the regional skew analysis were to be used to update flood-frequency data also for the 16 key sites.

To provide updated flood-frequency in the timeliest manner possible for the area of special interest in central California, the USGS focused initially on updates at gaged sites in a study area that consists of the Sacramento and San Joaquin-Tulare Basins. This study area (fig. 1) generally conforms to the Sacramento-San Joaquin River Basin study area defined by the ACOE. For consistency, the study area for the flood-frequency determinations in this report will be hereinafter referred to as the Sacramento-San Joaquin River Basin. 


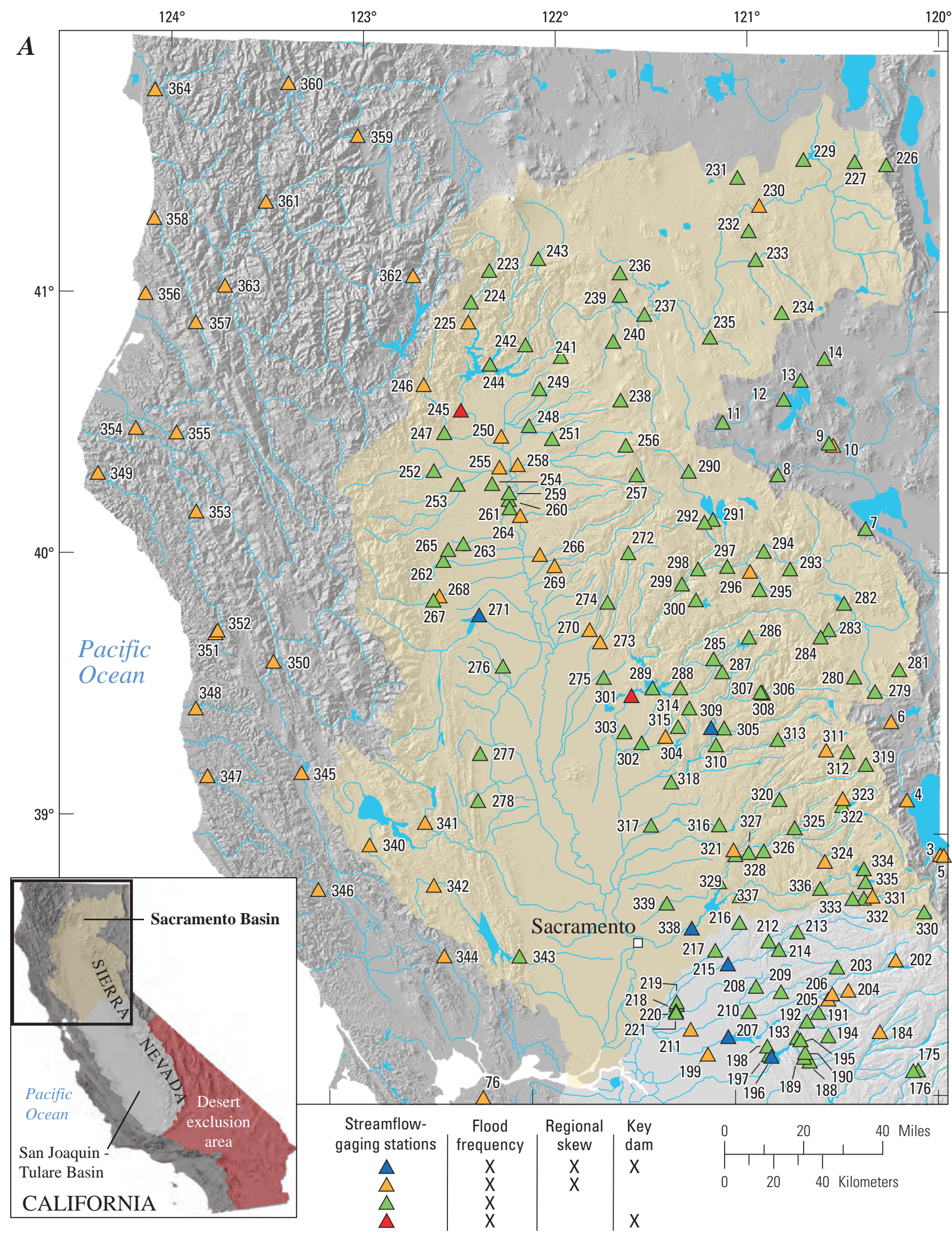

Figure 1. Stations in northern $(A)$, central $(B)$, and southern California $(C)$ selected for regional skew analysis outside the desert exclusion area and flood-frequency analysis in the Sacramento-San Joaquin River Basin, California. 


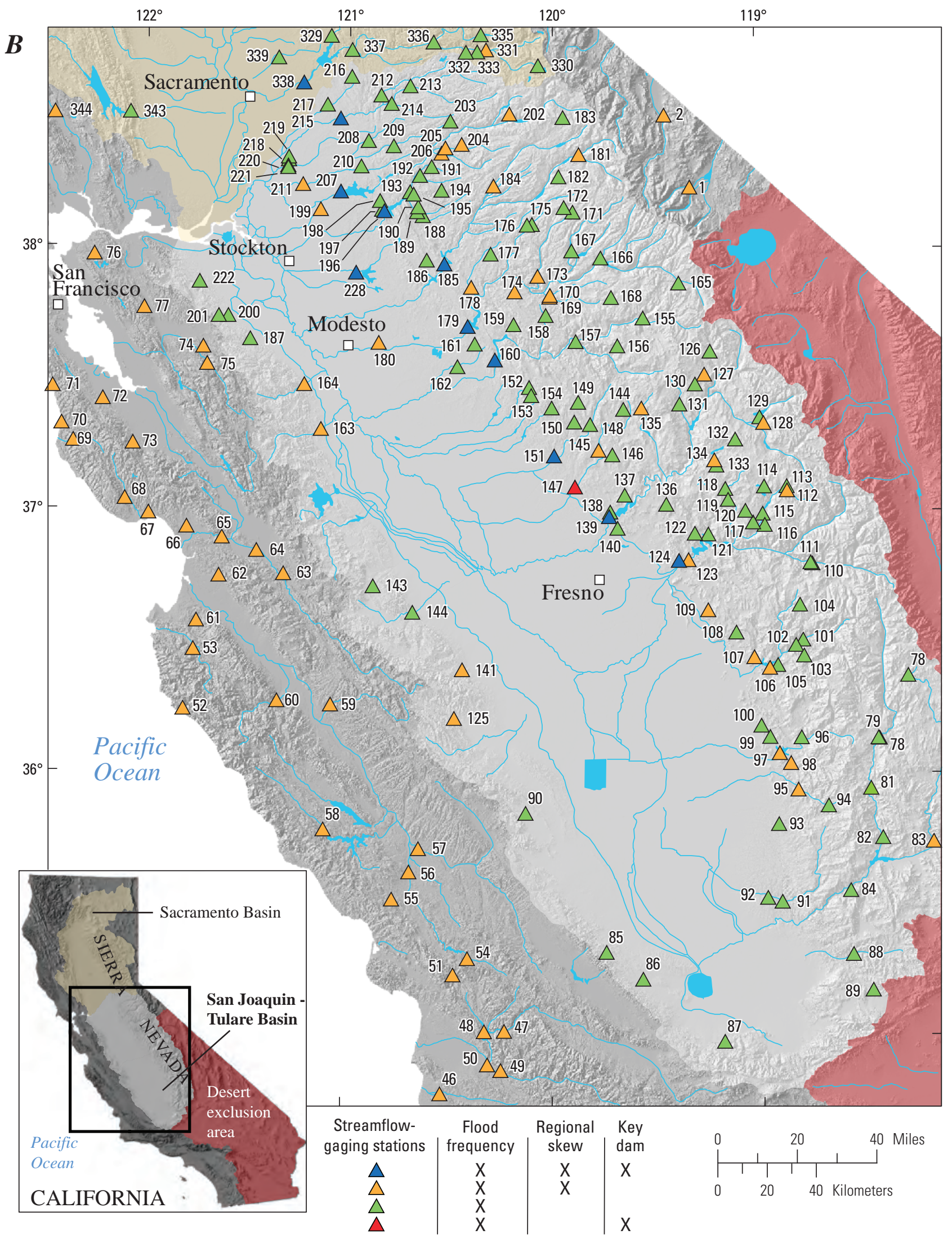

Figure 1.-Continued 


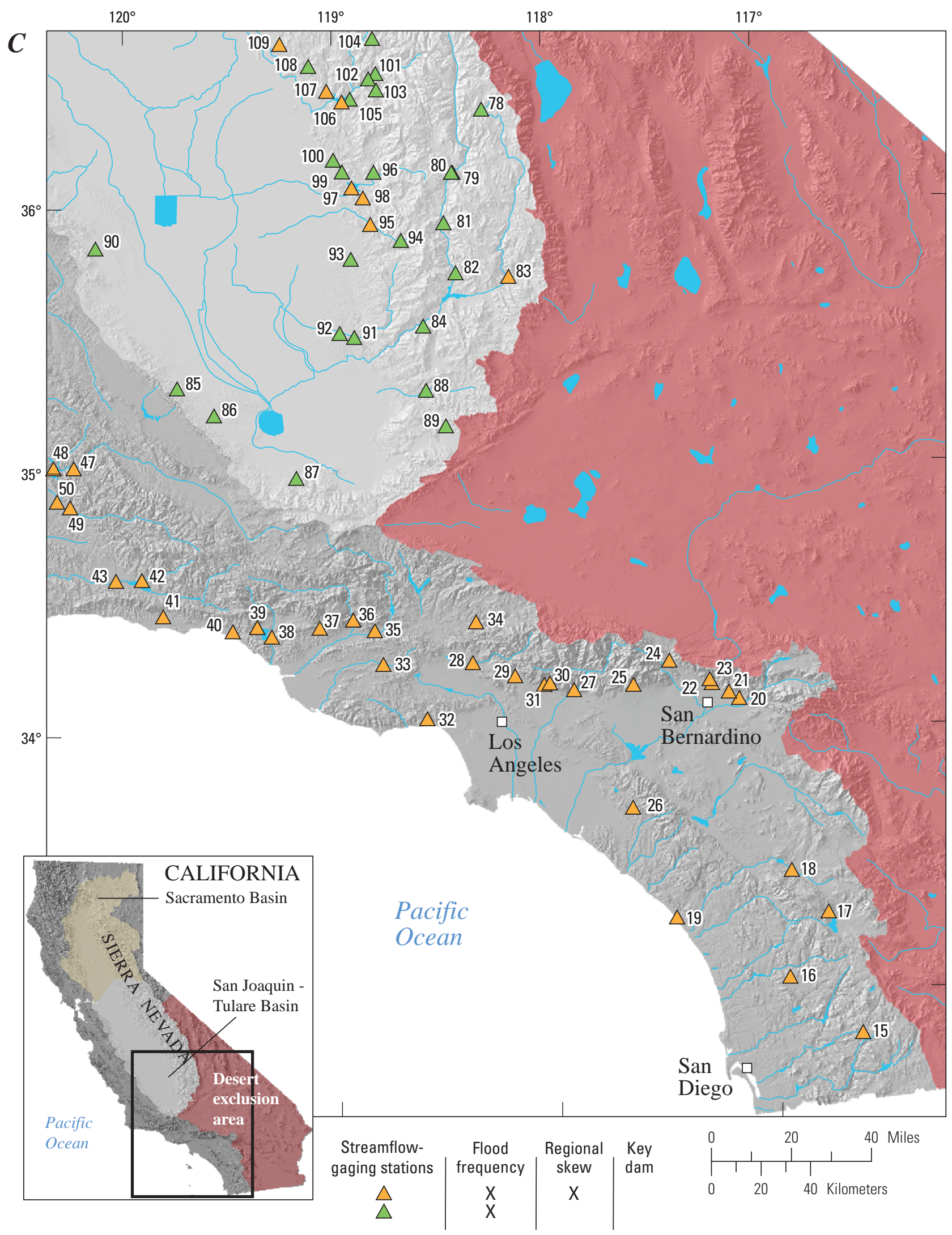

Figure 1.-Continued 


\section{Purpose and Scope}

The primary purposes of this report are to (1) convey the results of the regional skew analysis for California, outside the southeastern desert region, and (2) present floodfrequency information for the 158 sites used in the regional skew analysis and for an additional 206 selected sites in the Sacramento-San Joaquin River Basin. The databases for annual-peak discharge used for the regional skew analysis and the determination of flood frequency at selected sites are described. Because key dam sites identified by the ACOE were included in the regional skew analysis, unregulated, annual-peak discharge data at those sites needed to be constructed from estimated unregulated annual-maximumdaily discharge data. The maintenance of variance extension (MOVE) method was used to estimate peak-discharge data at the key dam sites and is described in Appendix A. The new EMA method was used to compute moments of the logarithms for the LP3 distribution to determine a station skew at each site to use in the regional skew analysis and to subsequently update flood frequency at all selected sites. Finally, the Bayesian GLS regression method used for the regional skew analysis is described in some detail, and extensions to the method required for use in this California study and various diagnostics for analyzing regional skew results are presented in $\underline{\text { Appendixes B }}$ and $\underline{\mathrm{C}}$.

Updated flood-frequency data at selected sites in the study area, based on the new regional skew relations and applying the LP3 method, are presented in table format, and some example flood-frequency curves are shown. Specific flood-frequency information provided are peak discharges having annual exceedance probabilities (frequencies) of 0.50, $0.20,0.10,0.05,0.02,0.01,0.005$, and 0.002. Exceedance probabilities often are expressed in terms of their reciprocals as recurrence intervals. A peak discharge having an annual exceedance probability of 0.01 , for example, has an associated recurrence interval of 100 years. Data in this report are presented both in terms of annual exceedance probability and recurrence interval.

\section{Study Area Description}

The study area for the regional skew analysis for California consists of the entire state outside the southeastern desert region (fig. 1). The excluded desert region largely conforms to the desert regions previously shown for California in a flood-frequency study for the southwestern desert region of the United States (Thomas and others, 1997). That previous study used data from several states to determine regional skew for the desert. The regional skew adopted by Thomas and others (1997) for the desert regions of the southwestern United States was zero.
Streamflow-gaging stations used in the regional skew analysis provided data for the broad range of hydrologic conditions throughout the study area. Along the California coast, streams drain the moderately rugged mountains of the Coastal Range, and annual-peak discharge most often results from large winter rainstorms. Annual-peak discharge from small streams, particularly those in drier areas of California may occasionally result from summer thunderstorms. Drainage within the flat valley floor of the Sacramento-San Joaquin River Basin is diffuse and often unpredictable because of the flat topography and agricultural land use, including extensive irrigation withdrawals and canal systems. Floods on the generally small streams that drain only the low-elevation foothills and valley floor areas commonly are the result of large winter rain storms, although floods may occasionally be a result of infrequent spring and summer rainstorms.

About a third of the stream sites selected for the regional skew analysis and many of the additional sites selected for the flood-frequency analysis in the Sacramento-San Joaquin River Basin are in the Sierra Nevada region near the eastern border of central California (ig. 1). This rugged, mountainous area has numerous streams that drain westward into the Sacramento and San Joaquin Rivers. The elevation of the northern part of the Sierra Nevada region is generally lower than the elevation of the southern part. Annual-peak discharges from streams draining the Sierra Nevada almost always occur during the winter and spring (November through June), and result from a complex interaction of rain and snow. A large winter storm might produce rain on the lower parts of a basin and snow on the colder, higher parts of the basin. Peak discharge from this kind of event would be less than if rain had fallen throughout the basin. Alternatively, the runoff from a large basin-wide rainstorm can be exacerbated if the higher-elevation part of the basin has a large volume of snowpack that is available for melting and subsequent runoff.

This complicated interaction of rain and snow on the production of annual-peak discharge is most prevalent for streams draining the Sierra Nevada, but it also occurs in other mountainous areas of California (Mount, 1995). The strength of the interaction depends largely upon the elevation of the basins above the gaged locations. The relation between average month of occurrence (timing) of the annual-peak discharge and mean basin elevation is shown in figure 2. The average month of occurrence of annual-peak discharge for each gaged site used in the regional skew analysis was computed, starting with October equal to 1, and plotted against mean basin elevation. Because relatively few annual peaks in California occur in July through September, those months were not used to compute the averages in figure 2 . Annual-peak discharges from streams with mean basin elevations less than about 4,000 ft have an average timing clustered between mid-November and mid-January and thus most likely represent runoff from rainstorms. On the other 


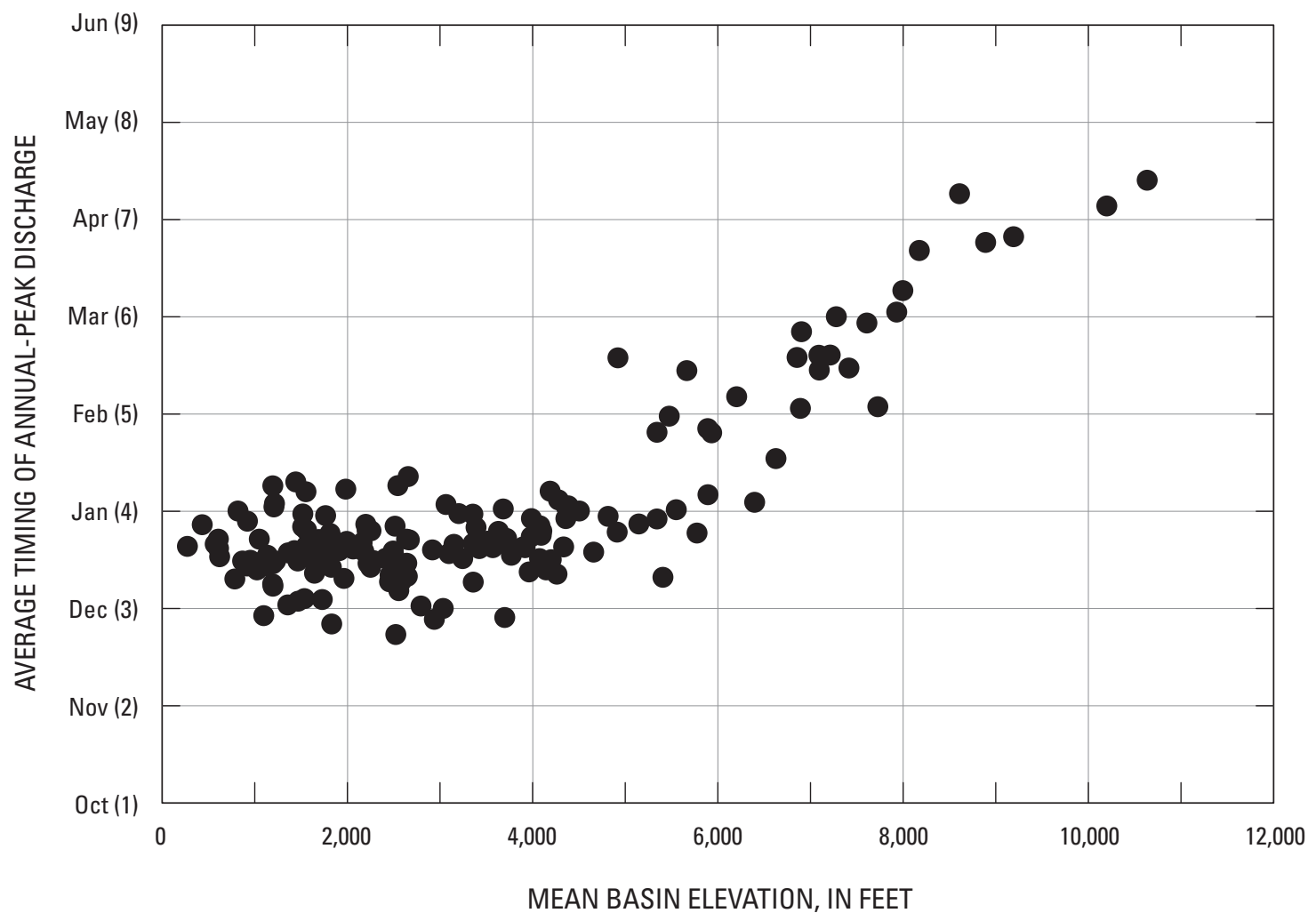

Figure 2. Relation between the average timing of peak discharge and mean basin elevation for 158 sites used for regional skew analysis in California. A small number of peaks in July, August and September were not used to determine average month of occurrence.

hand, the average timing of annual-peak discharge for mean basin elevations greater than $4,000 \mathrm{ft}$ generally increases with increasing elevation up to about 8,000 ft, where the average timing generally flattens at about April. March through May is generally the snowmelt period, so that floods that occur during this period are generally the result of snowmelt, or rain and snowmelt.

The implication of this trend in annual peak-discharge timing is that rain is the main cause of peak discharge in basins with mean elevations lower than about 4,000 ft, and that the interaction of rain and snow increases as elevation increases above $4,000 \mathrm{ft}$. For basins with mean elevations above about 8,000 ft, the effects of snow on peak discharge are predominant. As discussed later in the section titled Methodology Adjustments for California, the rain-snow interaction significantly affects regional skew in California and, at some sites, the degree of interaction may be so great that the annual-peak discharges may require separation into two groups for flood-frequency analysis (mixed-population analysis) as described in Bulletin 17B. The need for a mixedpopulation flood-frequency analysis is expected to be most appropriate for sites with mean basin elevations greater than about $8,000 \mathrm{ft}$.

\section{Data Used}

Annual-peak discharge data were used for several specific purposes. The databases for each purpose are described in the following sections.

\section{Regional Skew Database}

New regional skew values were developed for California by using a database of 145 USGS gaged sites having essentially unregulated annual peak-flow records of at least 30 years through water year 2006. In addition, the regional skew database included 13 of the 16 stations at key dam sites for which unregulated peak flow data were estimated from unregulated daily maximum discharge data furnished by the ACOE. All sites used for the regional skew analysis are shown in figure 1. Station locations and names, together with information about the annual peak-discharge and skew data are shown in table 1. Table 1 includes information about stations in the Sacramento-San Joaquin River Basin for which flood frequency information was developed. 
Although peak-discharge information for some of the 145 sites was recorded in the National Water Information System (NWIS) database with codes indicating that discharges were affected by regulation or diversion, the effects on peak discharge were considered negligible or the periods significantly affected by regulation or diversion were excluded from the analysis (table 1). Peak-discharge records at two sites on the San Benito River (stations 11158500 and 11158600) were combined into a single, longer record that was assigned an artificial station number of 11158699. Artificial station numbers ending in digits 99 were also assigned to the 16 stations at key dam sites for which unregulated peak flow data were estimated from unregulated daily maximum discharge data.

\section{Elimination of Redundant Sites and Other Non- typical Sites}

Redundancy results when the drainage basins of two gaged sites are nested, meaning that one is contained inside the other, and the sizes of the two basins are similar. Then, instead of providing two independent spatial observations depicting how drainage basin characteristics are related to skew (or flood quantiles), these two basins will likely have the same hydrologic response to a given storm and thus represent only one spatial observation. When sites are redundant, a statistical analysis using both gaged sites incorrectly represents the information in the regional data set (Gruber and Stedinger, 2008). To determine if two sites are redundant and thus represent the same hydrologic response, two pieces of information are considered: (1) whether their watersheds are nested and (2) the ratio of the basin drainage areas.

The first metric, normalized distance, is used to determine the likelihood the basins are nested. The normalized distance between two basin centroids, ND, is defined as (Veilleux, 2009)

$$
N D=\frac{D_{i j}}{\sqrt[4]{D_{i} D_{i j}}},
$$

where

$$
\begin{aligned}
& D_{i j} \text { is the distance between centroids of basin } \\
& i \text { and basin } j \text {, and }
\end{aligned}
$$

$D A_{i}$ and $D A_{j}$ are the drainage areas at sites $i$ and $j$.

The second measure, drainage area ratio (DAR), is used to determine if two nested basins are sufficiently similar in size to conclude that they essentially represent the same watershed for the purposes of developing a regional hydrologic model. The DAR is defined as

$$
D A R=M a x\left[\frac{D A_{i}}{D A_{j}}, \frac{D A_{j}}{D A_{i}}\right],
$$

where $D A_{i}$ and $D A_{j}$ have already been defined.

Two basins might be expected to be redundant if they are close together and similar in size. A previous study in the southeastern United States (Veilleux, 2009) determined that site pairs having ND less than or equal to 0.5 and D AR less than or equal to 5 were likely to have redundancy problems for determining regional skew, and therefore one of each site pair was removed from the regional skew analysis. The same values for ND and DAR were used to screen and remove sites from the regional skew analysis in California. Following screening, basin boundaries of identified pairs were examined to determine if the two sites were really nested.

The two key dam sites removed because of redundancy (Sacramento River at Keswick [station 11370599] and Feather River at Oroville [station 11407099]) had the two largest basins considered for the regional skew analysis. These large basins included several subbasins used in the regional skew analysis and thus truly were nested even though computed ND and DAR were greater than 0.5 and 5.0, respectively.

One key dam site, Fresno River below Hidden Dam near Daulton (station 11258099), was removed from the regional skew database because preliminary analysis indicated that an LP3 distribution provided only a very poor fit to the estimated annual peak-discharge record for both the lower and upper tail. Thus, station skew for this site likely did not represent the general variation in skew throughout the study area.

\section{Basin and Climatic Characteristics}

Various basin characteristics for each of the 158 sites in the regional skew analysis were derived from various national geographic information system (GIS) databases, including the National Hydrologic Dataset (NHDPlus), the National Land-Cover Dataset (NLCD), and the Parameter-Elevation Regressions on Independent Slopes Model (PRISM) climatic dataset based on data from 1970 to 2000. Table 2 gives the basin-characteristic names, descriptions, units, and sources of information. Table 3 shows basin characteristics for the 158 sites used in the regional skew analysis. At most of the sites shown in table 3, the drainage area determined from the NHDPlus GIS dataset closely matched the drainage area manually determined from topographic maps and reported in the NWIS peak-flow database. At two sites, station 11063000 and the key dam site at station 11259099, the drainage area determined from the GIS dataset differed from the drainage area reported in NWIS by more than 10 percent. For these two sites, the only basin characteristics considered to be 
reliable were those relating to basin elevation, and no other basin characteristics are given in table 3. For the two sites on the San Benito River where peak-discharge records were combined (station 11158500 and station 11158600), the basin characteristics measured for station 11158600 were used for the artificial combined-record station 11158699.

\section{Test for Trends in Long-Term Data Used for Regional Skew Analysis}

Flood-frequency analysis requires annual peak-flow data at each site that are random, independent, and generated by a process that is invariant (stationary) over time. Peak-flow data that indicate trends over time may reflect watershed or climatic changes that can significantly change flood characteristics and make flood-frequency estimates difficult to interpret and unreliable. To determine whether annual peak-discharge data are showing trends in California, 69 sites used in the regional skew analysis that had complete annual discharge records from 1977 to 2006 (30 years) were tested for monotonic trends using Kendall's tau, a non-parametric test for trends described by Helsel and Hirsch (1992). The locations of the 69 sites represented the locations of all 158 sites used for the regional skew analysis. The two primary outputs from the test were the tau value and the p-value. The tau value measures the strength of the correlation between the annual peak-flow values and time. Positive values of tau indicate increasing trends and negative values indicate decreasing trends. Trends generally are considered to be significant when the p-value is less than or equal to 0.05 . A p-value of 0.05 indicates that there is a 5 percent probability that the test will identify a trend when there is no actual trend present.

Of the 69 sites tested for a trend in annual-peak discharge from 1977 to 2006, none had tests with p-values less than or equal to 0.05 Table 4 lists the long-term sites used for the trend test and the data from that test. On the basis of the trendtest results, monotonic trends in annual-peak discharge are not considered to be a factor anywhere in California and thus do not affect the interpretation or overall reliability of floodfrequency results.

\section{Database for Stations at Key Dam Sites}

Unregulated peak-discharge data were estimated for 16 key dam sites selected by the ACOE. Ten of the 16 selected sites had concurrent recorded unregulated, annual-peak discharge and annual-maximum-daily discharge data obtained before dams were constructed. In addition to the concurrent unregulated peak-discharge and maximum-daily-discharge data, all sites had longer records of estimated, unregulated annual-maximum-daily discharge data that were developed and provided by the ACOE (John High, Chief, Hydrology Section, Sacramento District, U.S. Army Corps of Engineers, written commun., March 2009). These longer records of estimated, unregulated annual-maximum-daily discharge were used to estimate long-term records of annual-peak discharge that were subsequently used in the regional skew analysis for California. The 16 sites for which annual-peak discharges were estimated are shown in table 5 with a brief indication of the periods of discharge records. The estimated, unregulated annual-maximum-daily discharge data provided by the ACOE generally are the same values as those synthesized for a previous hydrologic study of streams in the Sacramento-San Joaquin River Basin (U.S. Army Corps of Engineers, 2002). The unregulated annual-maximum-daily discharge data provided by the ACOE for the 16 selected sites are shown in table 6.

\section{Database for Flood-Frequency Analysis in the Sacramento-San Joaquin River Basin}

Flood-frequency statistics were calculated for 256 sites in the Sacramento-San Joaquin River Basin in California. Included in the 256 sites were 50 of the 158 sites used in analyzing regional skew for all of California. Flood-frequency statistics were calculated for all 16 key dam sites also, even though only 13 of the 16 sites were used in the regional skew analysis. All sites for which flood-frequency was analyzed had minimally regulated peak-discharge records for at least 10 years. Periods of regulated peak-discharge record were excluded from analysis for sites that had at least 10 years of unregulated record. Some otherwise eligible sites also were excluded from flood-frequency analysis if 25 percent or more of the recorded peak discharges were zero, or if the number of peak discharges other than zero were less than 10. Finally, some otherwise eligible sites also were excluded if the LP3 distribution provided only a very poor fit to the recorded data. The very poor fits were most often the result of one or more large outliers in a short record period. Peak-discharge records for two sites on Panoche Creek (stations 11255500 and 11255575) were combined into a single, longer record that was assigned the artificial station number of 11255599. All sites that were analyzed for flood frequency are shown in figure 1 and listed in table 1. 


\section{Analytical Methods}

Various methods were used to analyze annual-peak discharge data in order to determine flood frequency at gaged sites. Those methods are described in the following sections.

\section{Flood Frequency Based on LP3 Distribution}

Flood-frequency estimates for gaged sites are computed by fitting a mathematical probability distribution to the series of annual-peak discharges as described in Bulletin 17B. The LP3 distribution, the Pearson Type 3 distribution applied to the logarithms (base 10) of annual-peak discharge data, is commonly used to estimate flood frequency in the United States and was used for the current California study.

The LP3 distribution is a three-parameter distribution that requires estimates of the mean, the standard deviation, and the skew coefficient of the population of logarithms of annual-peak discharge at each gaged site. The basic equation for determining flood frequency from the three parameters is the following:

$$
\log Q_{p}=\bar{X}+K_{p} S
$$

where

$$
\begin{aligned}
& Q_{p} \text { is the annual-peak discharge for the } \\
& \text { exceedance probability, } P \text {, } \\
& \bar{X} \text { is the mean of the logarithms of the annual- } \\
& \text { peak discharge, } \\
& K_{p} \text { is a factor based on the weighted skew } \\
& \text { coefficient and the exceedance probability, } \\
& P \text {, which can be obtained from Appendix } 3 \\
& \text { in Bulletin 17B, and } \\
& S \text { is the standard deviation of the logarithms of } \\
& \text { the annual-peak discharge, which is a } \\
& \text { measure of the degree of variation in the } \\
& \text { annual values about the mean value. }
\end{aligned}
$$

The mean, the standard deviation, and the skew coefficient can be estimated from the available sample data (recorded annual-peak discharges). However, a skew coefficient calculated from a small sample tends to be an unreliable estimator of the population skew coefficient. Accordingly, the guidelines in Bulletin 17B indicate that the skew coefficient calculated from at-site sample data (station skew) needs to be weighted with a generalized, or regional, skew determined from an analysis of selected long-term gaged sites in the study region. The value of the skew coefficient used in equation 3 is this weighted skew that is based on station skew and regional skew. As previously described, Bayesian generalized least squares (GLS) regression, a newly developed method for determining regional skew, was used for the current study. The regional skew analysis is described in detail in a later section of the report titled Statistical Analysis of Regional Skew. Some of the more technical details of the mathematics involved are more fully presented in Appendixes B and $\mathrm{C}$.

Equation 3 forms the basis for calculating flood frequency at gaged sites, but Bulletin 17B also provides methods for adjusting the results for zero flows, testing and adjusting for low outliers, and adjusting for historical floods that occur outside the period of systematic peak-discharge data collection. While these adjustments generally improve floodfrequency estimates, the new expected moments algorithm (EMA) incorporates historical discharges more efficiently and allows peak discharges that are known only to be within some range of plausible values (interval or bounded discharges) to be used in flood-frequency analysis. Consequently, the EMA was used in the current study.

\section{Expected Moments Algorithm (EMA)}

The EMA method was used for an initial LP3 frequency analysis in order to determine station skew for all sites used in the regional skew analysis. For sites that have systematic annual-peak discharge records for complete periods, no low outliers, and no historical flood information, the EMA method calculates identical values of the LP3 parameters (mean, standard deviation, and station skew) as the conventional method-of-moments described in Bulletin 17B. The EMA method, however, can incorporate into the analysis censored peak-discharge data. Censored data may be expressed in terms of discharge perception thresholds during historical periods outside the period of systematic data collection. For example, a site may have some historical information that indicates that a large recorded peak discharge of $Q_{\text {hist }}$ was the largest since 1900, before systematic data collection was started in 1930 . Each annual peak from 1900 to 1930 can thus be characterized as a censored discharge whose value is known not to have exceeded the perception threshold, $Q_{\text {hist }}$, and estimates of those bounded discharges between 0 and $Q_{\text {hist }}$ can be used in the LP3 flood-frequency analysis. In the same way, the EMA method allows use of bounded discharges to characterize any missing data during periods of systematic data collection. These missing peak discharges can be described by perception thresholds or, if we have more knowledge about the likely range of missing discharge, by interval discharges that have specific upper and lower bounds. For example, if a peak was not recorded because the peak stage did not reach the elevation of the gage, the missing peak might be characterized as an interval discharge with a range that is bounded by zero and the peak discharge associated with the elevation of the gage. Missing peaks during periods of systematic data collection typically are ignored when the conventional LP3 method is used.

Censored data also can be low outliers in the systematic record. Low outliers are peak discharges that are significantly smaller than other recorded peak discharges and consequently 
often have a large effect on the LP3 distribution fit to all the recorded data. The primary focus of flood-frequency studies is the upper tail of the distribution (larger, rarer peak discharges), so closely fitting the upper tail is more important than fitting all data points, particularly abnormally low peak discharges. The LP3 distribution only has three adjustable parameters and thus may not be able to always fit the smallest and the largest flood flows. Accordingly, the conventional LP3 method described in Bulletin 17B incorporates a Grubbs-Beck statistical test to determine when a recorded peak discharge is unusually small compared with all other recorded peaks and should be treated as a low outlier. Bulletin 17B further describes a conditional probability adjustment that is made when low outliers are identified. The EMA also makes use of the Grubbs-Beck test to identify low outliers. In this case, the test is iterated to determine if censoring an outlier causes any of the remaining peaks to be identified as an outlier. The EMA computation used to fit an LP3 distribution when low outliers are censored is different from that described in Bulletin 17B. Although the Grubbs-Beck test provides a reasonable way to identify low outliers that may result in fitting problems with the LP3 distribution, sometimes not all low peak discharges that cause fitting problems are identified in either the conventional LP3 method or in the EMA program. Thus, when either method is applied, sometimes a user-specified lowoutlier threshold that is larger than the values identified by the Grubbs-Beck test is used. Individual flood-frequency curves were visually inspected to determine whether one or more peak discharges in the lower tail (discharges with an annual exceedance probability of 0.50 or greater) of the distribution might be adversely affecting the fit of the upper tail of the frequency curve and thus require censoring. For a few sites, the curve fit for the upper tail was substantially improved by censoring the complete lower tail of the distribution. However, the substantial improvement came at the expense of a large increase in the mean square error (MSE) of the station skew as computed by the EMA program. All sites for which a userspecified low-outlier threshold was used are noted in table 1.

Although the EMA allows the use of censored data that can significantly improve flood-frequency analyses, establishing reasonable bounds on the discharges can require considerable judgment on the part of the analyst. Fortunately, results from the EMA program generally are not sensitive to small changes in the perception thresholds or bounds used for interval discharges.

In practice, the EMA provides estimates of missing, but bounded, discharge in a 5 -step iterative process described by England (2003b):

1. Estimate an initial set of the three sample statistics (mean, standard deviation, and skew) from the logarithms of peak-discharge data with known magnitudes. These discharges are typically recorded peaks from the gaging station records and possibly some historical discharges. At this step, interval (bounded) discharges are not included.
2. Use the initial sample statistics from step (1) to estimate a set of LP3 distribution parameters .

3. Use the set of LP3 parameters from step (2) to estimate a new set of sample statistics based on the complete data set, including unknown discharges less than a threshold, unknown discharges that exceed a threshold, and unknown discharges with specific lower and upper bounds. The threshold values and lower and upper bounds are used as the initial estimates of the unknown discharges.

4. Use this new set of moments to estimate a new set of LP3 parameters. These estimates are based on expected values given that the unknown discharges are less than the upper thresholds and bounds and greater than the lower thresholds and bounds.

5. Compare the parameters from step (4) with those computed from step (2). Repeat steps (3) and (4) until the parameter estimates converge. The main equations used by EMA to make the estimates in the iterative process are listed by Cohn and others (1997), England (1999), and England and others (2003a,b). Cohn and others (2001) describe the EMA computation for evaluating the sampling variance of parameters and quantiles.

\section{Statistical Analysis of Regional Skew}

Tasker and Stedinger (1986) developed a weighted least squares (WLS) procedure for estimating regional skew coefficients that is based on sample skew coefficients corresponding to the logarithms of annual peak-discharge data. Their method of regional analysis of skewness estimators accounts for the precision of the skewness estimator for each station, which depends on the length of record for each station and the accuracy of the regional skew model. More recently, Reis and others (2005), Gruber and others (2007), and Gruber and Stedinger (2008) developed a Bayesian generalized least squares (GLS) regression model for regional skew. While WLS regression accounts for the precision of the regional model and the effect of the record length on the variance of skewness estimators, GLS regression considers the cross correlations among the skewness estimators also. As explained later in the report section titled Methodology Adjustments for California, the cross correlations among the skewness estimators were important for the California regional skew study. The new Bayesian GLS regression procedures describe the precision of the estimated model error variance, a pseudo analysis of variance and enhanced diagnostic statistics (Griffis and Stedinger, 2007). A Bayesian GLS regional skew analysis was used in recently completed flood-frequency studies for the Southeastern United States (Feaster and others, 2009; Gotvald and others, 2009; Weaver and others, 2009). 
The California regional skew study described here is based on use of Bayesian GLS regression procedures. However, the statistical procedures used in the Southeastern United States regional flood-frequency study had to be extended because of two problems that arose in the analysis of the California data set. The first problem was the difficulty in estimating the cross correlation of at-site skew estimators that were determined from the EMA analysis of the California regional-skew data set. This difficulty arose because EMA allows for censoring of low outliers and the use of estimated interval discharges for missing recorded data, and computing cross correlations when peak discharges are not represented by single values is difficult. The second problem was the extensive cross-correlation among concurrent recorded peak discharges in California. This extensive cross-correlation was not present in previous regional skew studies using Bayesian GLS regression procedures and required special attention in the analysis. To properly account for the cross-correlation problems and develop a suitable regression model and regression diagnostics, Bayesian WLS and GLS regressions were combined. In essence, the regression parameters of the regional skew model for California were determined using Bayesian WLS regression procedures, and the accuracy of the regression parameters and the regression models were determined using a special Bayesian GLS regression procedure. Those procedures are described in Appendixes B and $\underline{\mathrm{C}}$.

\section{Regional Regression Models}

The basic model for a regional (or generalized) skew analysis when there are $k$ explanatory variables and $n$ stations is

$$
\hat{\gamma}=\mathbf{X} \boldsymbol{\beta}+\boldsymbol{\varepsilon}
$$

where

$\hat{\gamma}$ is an $(n \times 1)$ vector of the unbiased estimated at-site skew coefficients for every station (see Appendix B for more discussion about unbiased skew estimators),

$\mathbf{X}$ is an $(n \times k)$ matrix of $k$ basin characteristics with a column of ones corresponding to a constant in the model,

$\boldsymbol{\beta}$ is a $(\mathrm{k} \times 1)$ vector of model coefficients, $\boldsymbol{\varepsilon}$ is the $(\mathrm{n} \times 1)$ vector of total errors, including both model and sampling errors where $E[\varepsilon]=0$ and $\Lambda$ is the covariance matrix that represents $\mathrm{E}\left[\boldsymbol{\varepsilon \varepsilon} \boldsymbol{\varepsilon}^{\top}\right]$.
The matrix $\boldsymbol{\Lambda}$ is computed as the sum of two covariance matrices (Reis and others, 2005) $\sigma_{\delta}^{2} \mathbf{I}+\boldsymbol{\Sigma}(\hat{\gamma})$, where $\sigma_{\delta}^{2}$ is the model error variance describing the precision with which the proposed model $\mathbf{X} \boldsymbol{\beta}$ can predict the true skews, which are denoted $\gamma_{i}$, and the matrix $\boldsymbol{\Sigma}(\hat{\gamma})$ represents the sampling variances and covariances of the skewness estimators $\hat{\gamma}_{i}$. The value of $\boldsymbol{\Sigma}(\hat{\gamma})$ is determined by the length of record at each station, the regional skew, and the cross-correlation of the concurrent flows.

The standard WLS or GLS estimator of $\boldsymbol{\beta}$, which for given $\boldsymbol{\Lambda}$ is unbiased with minimum variance, is

$$
\hat{\boldsymbol{\beta}}=\left(\mathbf{X}^{\top} \boldsymbol{\Lambda}^{-1} \mathbf{X}\right)^{-1} \mathbf{X}^{\top} \boldsymbol{\Lambda}^{-1} \hat{\boldsymbol{\gamma}}
$$

In WLS, the $\boldsymbol{\Lambda}$ matrix has non-zero elements only on the diagonal. In GLS, the $\boldsymbol{\Lambda}$ matrix nominally has the same diagonal elements, but the off-diagonal elements are also nonzero to reflect the cross-correlation among the at-site skewness estimators $\hat{\gamma}_{i}$.

A critical step for a GLS analysis is estimating the cross-correlation of the skewness estimators. Martins and Stedinger (2002) used Monte Carlo experiments to derive a relation between the cross-correlation of the skew coefficient estimators at two stations $i$ and $j$ as a function of the crosscorrelation of concurrent annual maximum flows, $\rho_{\mathrm{ij}}$ :

$$
\hat{\rho}\left(\hat{\gamma}_{\mathrm{i}}, \hat{\gamma}_{\mathrm{j}}\right)=\operatorname{Sign}\left(\rho_{\mathrm{j}}\right) \mathrm{cf} \mathrm{ij}_{\mathrm{ij}}\left|\rho_{\mathrm{j}}\right|^{\mathrm{K}} \text {, }
$$

where

$\rho_{\mathrm{ij}}$ is the cross-correlation of concurrent annualpeak discharges for two gaged stations,

$\kappa$ is a constant between 2.8 and 3.3, and $\mathrm{cf}_{\mathrm{ij}}$ is a factor that accounts for the sample size difference between stations and their concurrent-record length and is defined as follows:

$$
c f_{i j}=n_{i j} / \sqrt{\left(n_{i j}+n_{i}\right)\left(n_{i j}+n_{j}\right)},
$$

where

$$
\begin{aligned}
& n_{i j} \text { is the length of the period of concurrent } \\
& \text { record, }
\end{aligned}
$$

$n_{i}$ and $n_{j}$ are the number of nonconcurrent observations corresponding to sites $i$ and $\mathrm{j}$, respectively. 


\section{Cross-Correlation Model of Concurrent Annual- Peak Discharge}

A cross-correlation model for the annual- peak discharges in California was developed using 21 sites with more than 65 years of concurrent records containing no censored peaks. None of the key dam sites identified by the ACOE were used in this analysis because annual-peak discharge at those sites was estimated. Various models relating the cross-correlation of the concurrent annual-peak discharge at two sites, $\rho_{\mathrm{ij}}$, to various basin characteristics were considered. In general, a logit model using the Fisher $Z$ Transform $(Z=\log [(1+r) /(1-r)])$ provided a convenient transformation of the sample correlations $r_{i j}$ from the $(-1,+1)$ range to the $(-\infty,+\infty)$ range. The adopted model for estimating the cross-correlations of concurrent annualpeak discharge at two stations, which used the distance between basin centroids, $D_{i j}$, as the only explanatory variable, is

where

$$
\rho_{\mathrm{j}}=\frac{\exp \left(2 \mathrm{Z}_{\mathrm{ij}}\right)-1}{\exp \left(2 \mathrm{Z}_{\mathrm{ij}}\right)+1}
$$

$$
Z_{i j}=\exp \left(0.27-0.0037 D_{i j}\right) \cdot
$$

An ordinary least squares regression analysis based on 159 station-pairs indicated that this model is as accurate as one having 52 years of concurrent annual peaks from which to calculate a cross-correlation. Figure 3 shows the fitted relation between $\mathrm{Z}$ and the distance between the basin centroids together with the plotted sample data from the 159 station-pairs of data. Figure 4 shows the functional relation between the untransformed cross correlation and the distance between the basin centroids in the California study and the Southeastern United States study. The cross correlations decrease more gradually with increasing distance between the basin centroids in California than they do in the Southeastern United States. This difference between California and the Southeastern United States indicates that large floodproducing storms cover more area in California than in the Southeastern United States.

The cross-correlation model was used to estimate site-to-site cross correlations for concurrent annual-peak discharges at all pairs of sites. Figure 5 is a histogram of the relative frequency of the distribution of the estimated cross correlations among the 158 sites in the California data set and, for comparison, the distribution of the cross correlations among 342 sites in the Southeastern United States.

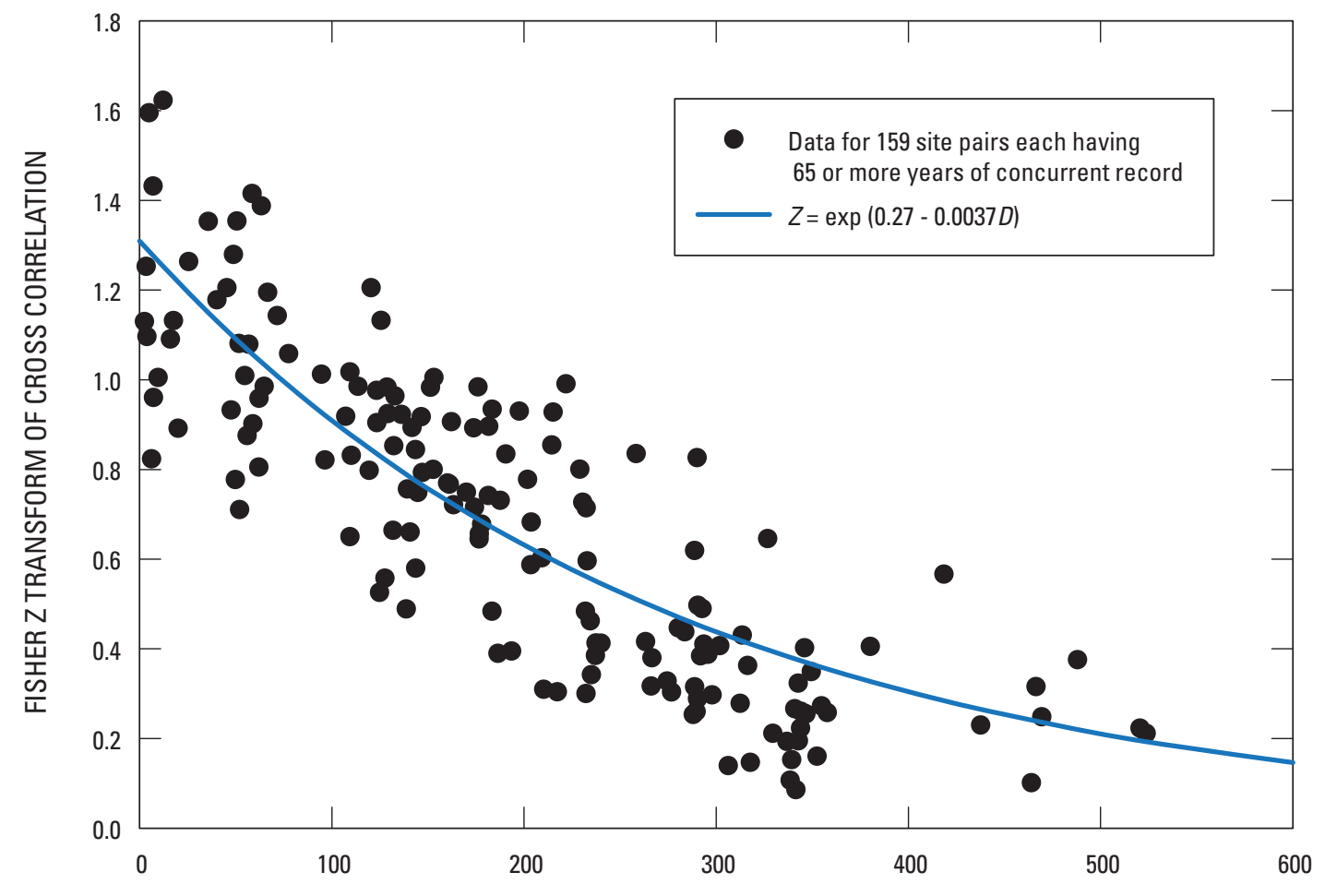

DISTANCE BETWEEN BASIN CENTROIDS, IN MILES

Figure 3. Relation between the Fisher $Z$ transform ( $Z$ ) of logs of annual-peak discharge and distance between basin centroids for 159 station-pairs in California. 


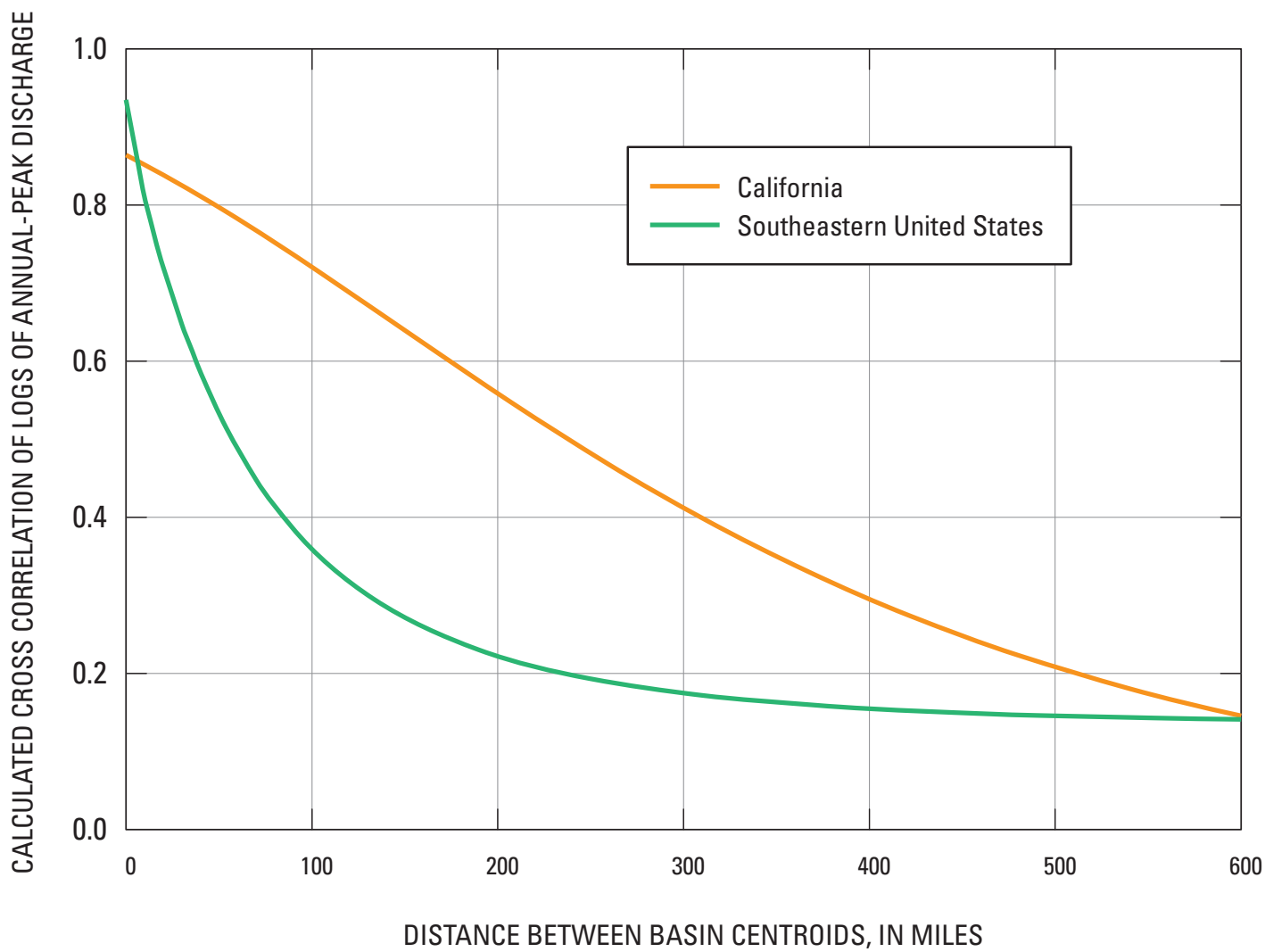

Figure 4. Relation between the cross-correlation of logs of annual-peak discharge and the distance between basin centroids based on data from 159 station-pairs in California and 1,317 station-pairs in the Southeastern United States.

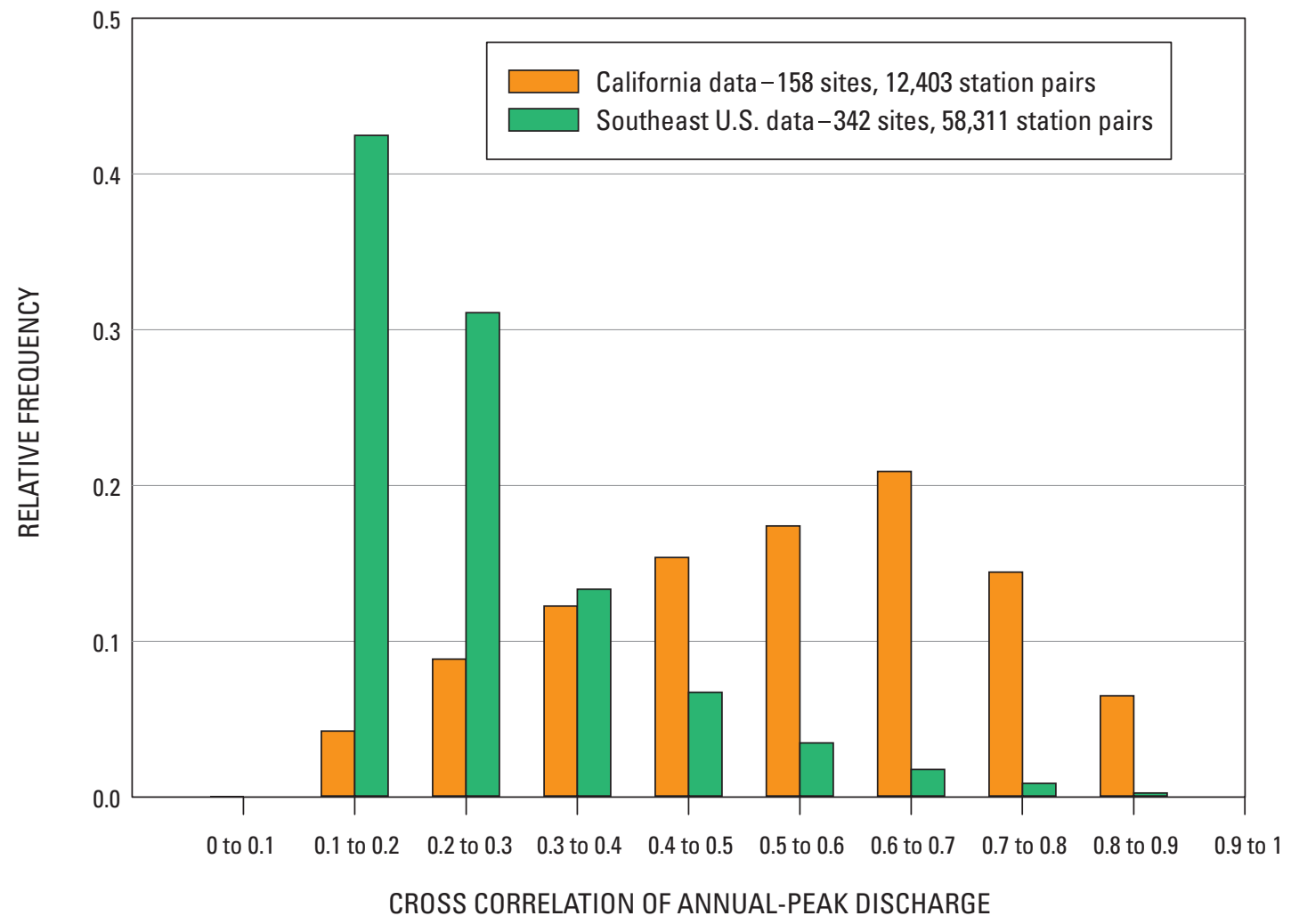

Figure 5. Histogram of relative frequency of calculated cross-correlation values in California (158 sites) and in the Southeastern United States (342 sites). 


\section{Methodology Adjustments for California}

The Southeastern United States regional skew analysis illustrates how a Bayesian GLS analysis would generally proceed (Feaster and others, 2009; Gotvald and others, 2009; Veilleux, 2009; and Weaver and others, 2009). However, when a Bayesian GLS analysis of the California data set was attempted, reliable results were not obtained because of the large cross correlations. Thus, an alternative procedure that uses a combination of Bayesian WLS and GLS was developed so that the regional skew analysis would provide more stable and defensible results. The need for the alternative procedure and the specific computational steps for the procedure are described in Appendix B. The results of the California regional skew regression using the alternative procedure are provided below.

All of the available basin characteristics were initially considered as explanatory variables in the regression analysis for regional skew. The one key basin characteristic that was statistically significant in explaining the site-to-site variability in skew was the mean basin elevation (ELEV). Table 7 gives the final results for three models: a constant skew denoted "Constant," a model that uses a linear relation between skew and mean basin elevation denoted "Elev," and a model that uses a nonlinear relation between skew and mean basin elevation denoted "NL-Elev."

As shown in table 7, the linear Elev model has a Pseudo $\mathrm{R}_{\delta}^{2}$ of 41 percent, while the nonlinear NL-Elev model has a larger Pseudo $R_{\delta}^{2}$ of 48 percent and a slightly smaller $A V P_{\text {new. }}$. The Pseudo $R_{\delta}^{2}$ values describe the fraction of the variability in the true skews explained by each model (Gruber and others, 2007). A Constant model does not explain any variability, so the Pseudo $R_{\delta}^{2}$ is equal to 0 percent. Also, the posterior mean of the model error variance, $\sigma_{\delta}^{2}$, for the NL-Elev model is 0.10 , which is smaller than that for the linear Elev model $\left(\sigma_{\delta}^{2}=0.12\right)$ and substantially smaller than that for the Constant model $\left(\sigma_{\delta}^{2}=0.20\right)$. The average sampling error variance (ASEV) in table 7 is the average error in the regional skewness estimator at the sites in the data set.

The average variance of prediction at a new site $\left(\mathrm{AVP}_{\text {new }}\right)$ corresponds to the mean square error (MSE) used in Bulletin 17B to describe the precision of the generalized skew. In table 7, the NL-Elev model has the lowest $\mathrm{AVP}_{\text {new }}$, equal to 0.14 . However, this $\mathrm{AVP}_{\text {new }}$ is an average value computed by averaging the variance of prediction at a new site $\left(\mathrm{VP}_{\text {new }}\right)$ for all of the 158 sites in the California study. Just as generalized skew varies from site to site, depending upon mean basin elevation, so too do the values of $\mathrm{VP}_{\text {new }}$. Table 8 gives values of the variance of prediction for the regional skew, $\mathrm{VP}_{\text {new }}$, and effective record length (ERL) for the NL-Elev model for values of mean basin elevation between 0 and 11,000 ft.
Thus, the NL-Elev regional skew model for California has effective record lengths ranging from 52 years to 65 years, depending upon the mean basin elevation. $\mathrm{A} \mathrm{VP}_{\text {new }}$ ranging from about 0.13 to 0.17 is a marked improvement over the Bulletin 17B skew map, whose MSE is 0.302 (Interagency Advisory Committee on Water Data, 1982) for a corresponding effective record length of only 17 years.

The nonlinear elevation model provides a reasonable fit for the California regional skew data (fig. 6). While the more complicated nonlinear model is not that different from the simpler linear elevation model, the nonlinear model provides smaller values of positive skew at high elevations and less negative values of skew for low elevations. For example, when a mean basin elevation is zero at sea level, the nonlinear model provides a regional skew of -0.62 , while the linear elevation model provides a regional skew of -0.76 . Conversely, when a mean basin elevation is $11,000 \mathrm{ft}$, the nonlinear model provides a regional skew of 0.61 , while the linear model provides a regional skew of 0.79 . These differences, though subtle, are significant, and the nonlinear model indicates that regional skew flattens out in the tails instead of continually increasing in absolute value. This flattening of skew at both low and high elevations is consistent with the relation between the timing of annual-peak discharge and the elevation, which is largely reflective of the degree of rain-snow interaction affecting peak discharge. Annual peak-discharges from basins that have mean elevations less than about 4,000 ft have little rain-snow interaction (fig. 2) and thus, might be expected to have constant or near-constant regional skews. Likewise, at the other extreme, basins at very high elevations tend to have annual-peak discharges that are predominantly the result of spring snowmelt events. Thus, beyond some point, higher elevation has less effect on the distribution of annual maxima because few, if any, of the flood peaks are caused by winter rainfall events.

Only six sites that have a mean basin elevation greater than about 8,000 ft were used in the regional skew analysis (fig. 2). Because of the scarcity of such high-elevation sites, the calculated regional skew values for high-elevation sites may be less reliable than those for lower-elevation sites. In addition, combining a few large, winter-rain caused peaks with many more smaller, spring snowmelt peaks often results in fitted frequency curves from the LP3 distribution with a sharp upward curvature that may poorly represent the true frequency of the largest floods. Peak-discharge data for sites that have mean basin elevations above about $8,000 \mathrm{ft}$ need to be examined to determine if a mixed-population analysis for determining flood frequency described in Bulletin 17B might be more appropriate than the standard LP3 method. When a mixed-population analysis is used the rain-caused floods and snowmelt floods are analyzed separately, and the separate frequency curves are combined to represent the joint 


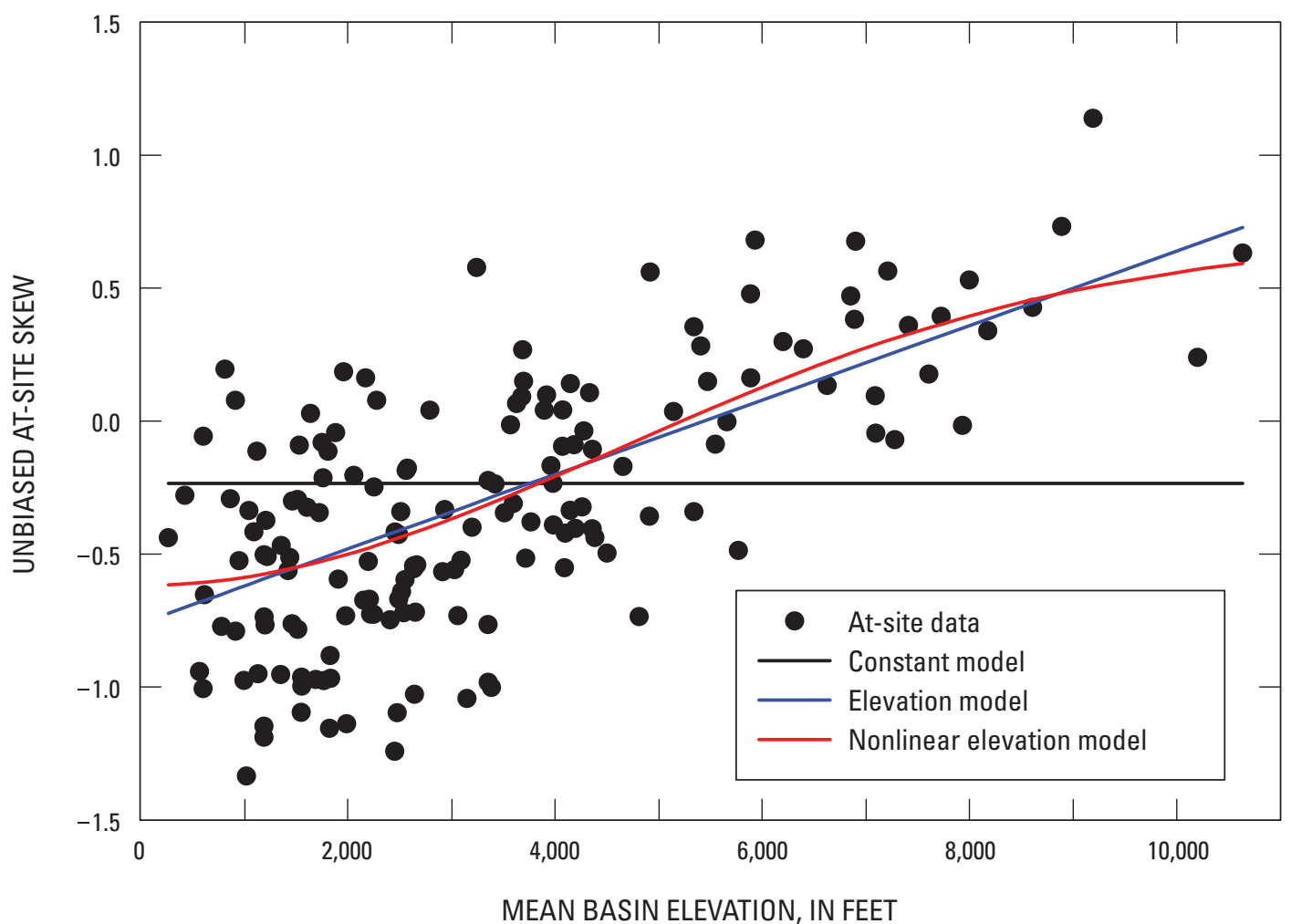

Figure 6. Relations between the unbiased at-site skew and the mean basin elevation for 158 sites in California. The lines represent a model based on a constant skew (Constant), a model with a linear relation between skew and mean basin elevation (Elev), and a model with a nonlinear relation between skew and mean basin elevation (NL-Elev). The models were developed from Bayesian weighted least squares and generalized least squares (WLS-GLS) analyses.

probability of flooding from any cause (Murphy, 2001). The Sierra Nevada in California has previously been indicated as an area having a mixture of rain and snowmelt events (Interagency Advisory Committee on Water Data, 1982, p. 16), and the ACOE commonly analyzes rain-caused floods separately from snowmelt-caused floods in this area (U.S. Army Corps of Engineers, Sacramento District, 2002).

\section{Flood-Frequency Results}

Flood-frequency estimates for 158 stations used in the regional skew analysis and 206 additional stations in the Sacramento-San Joaquin River Basin are shown in table 1 at the back of the report. Table 1 includes information about peak-discharge record lengths, historical record periods, censored data and thresholds, and skew coefficients also. All flood-frequency estimates in table 1 were developed by using the EMA program.
The flood-frequency estimates were calculated by applying the LP3 probability distribution, with a weighted skew as described in Bulletin 17B, to the annual peakdischarge data at the stations. The weighted skew is determined by weighting the station skew and the regional skew inversely proportional to their respective mean square errors, as shown in the following equation:

$$
G_{w}=\frac{M S E_{R}\left(G_{S}\right)+M S E_{S}\left(G_{R}\right)}{M S E_{R}+M S E_{S}},
$$

where

$G_{w}$ is the weighted skew, $G_{S}$ is the station skew, $G_{R}$ is the regional skew, and $M S E_{R}$ and $\mathrm{MSE}_{S}$ are the mean square error of the regional and station skew, respectively. 
The $\mathrm{MSE}_{\mathrm{R}}$ is equivalent to the variance of prediction for a new site $\left(\mathrm{VP}_{\text {new }}\right)$ described in the previous section. Bulletin 17B provides equations for calculating $\mathrm{M} \mathrm{SE}_{S}$, but these equations may not be reliable when peak-flow data are heavily censored. The EMA program, which can use heavily censored data, uses a first-order approximation for $\mathrm{MSE}_{S}$, developed by Cohn and others (2001).

Flood-frequency curves show the LP3 distribution fitted to the recorded annual peak-discharge data for selected sites in California (figs. 7-10). Each figure shows the fitted curves based on station skew and weighted skew with the 90 -percent confidence interval for the true flood-frequency distribution based on use of the weighted skew. The confidence interval determined by the EMA program defines a confidence band (difference between the upper and lower confidence limits) that generally is wider than the confidence band calculated using the conventional LP3 analysis, because the EMA results include the uncertainty in the estimated skew. As described by Cohn and others (2001), the EMA program produces more realistic confidence intervals than does the simple method used in the conventional LP3 analysis.
Figures 7 and 8 contain typical flood-frequency curves for stations that have no censored peak-flow data (no low outliers or historical periods) and that have mean basin elevations below 4,000 ft. These EMA-developed curves are identical to those that would be produced by a conventional LP3 frequency analysis and also represent flood-frequency curves for stream sites with little or no snowmelt runoff. The flood-frequency curves in figure 7 are for a station that has a relatively long period of record,73 years (Saratoga Creek, station 11169500), whereas the flood-frequency curves in figure 8 are for a station that has a short flow record, 11 years (Kingsbury Creek, station 11402700). The fitted curves based on station skew and on weighted skew are different in figure 7, indicating a substantial difference between regional skew and station skew for this long-record site. Also, the confidence interval for the long-record site in figure 7 is narrower than the confidence interval for the short-record site in figure 8 . Many of the sites for which flood-frequency estimates were developed are for sites that had little or no censored data (table 1). Thus, the flood-frequency curves shown in figures 7 and $\underline{8}$ are typical — with varying degrees of scatter, widths of confidence intervals, and record lengths - of those for many of the sites where snow has little or no effect on peak discharge.

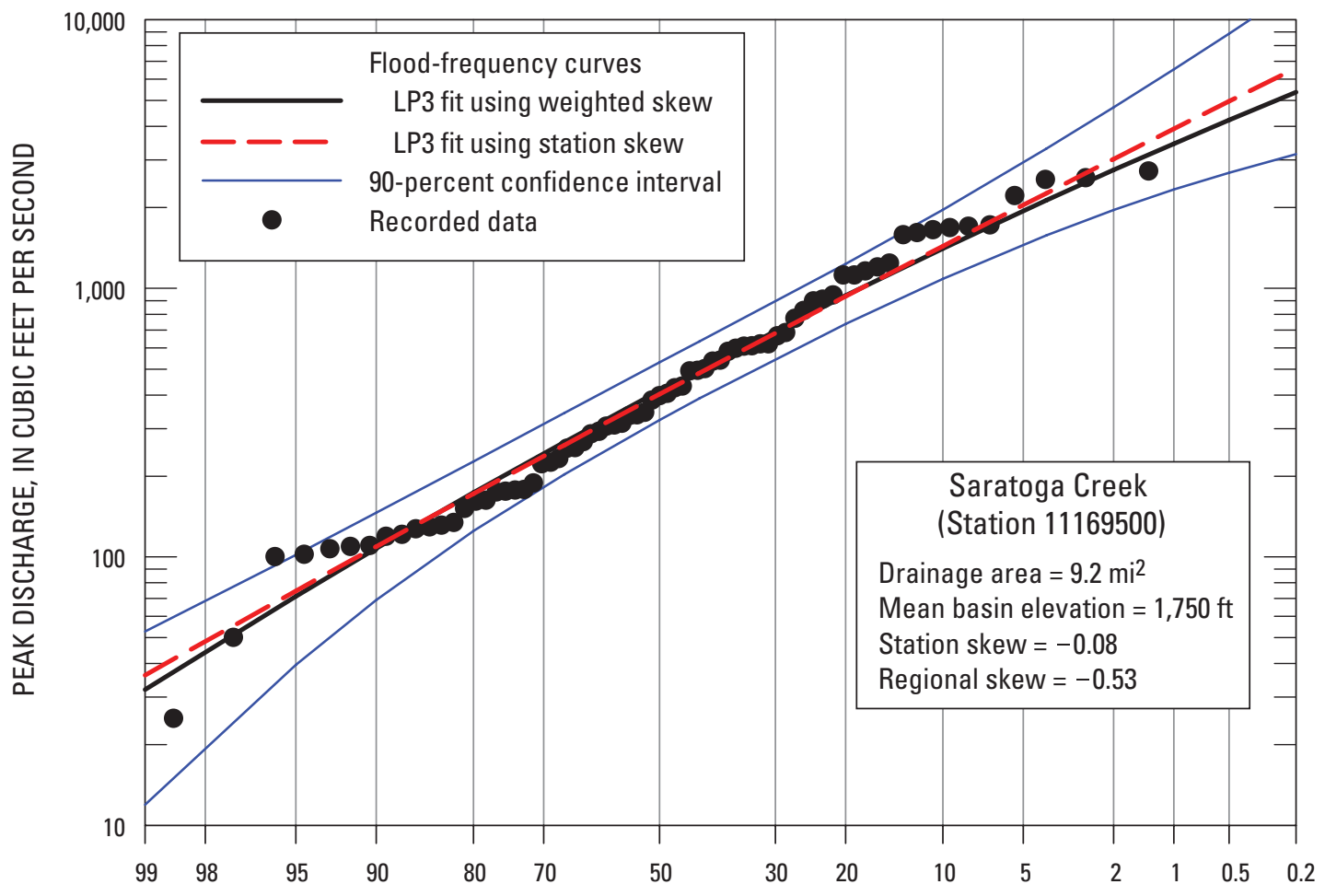

ANNUAL EXCEEDANCE PROBABILITY, IN PERCENT

Figure 7. Flood-frequency curves for Saratoga Creek, California, (station 11169500) based on 73 years of recorded data with no censoring of annual-peak discharge. LP3, log Pearson Type 3; $\mathrm{mi}^{2}$, square mile; $\mathrm{ft}$, foot. 


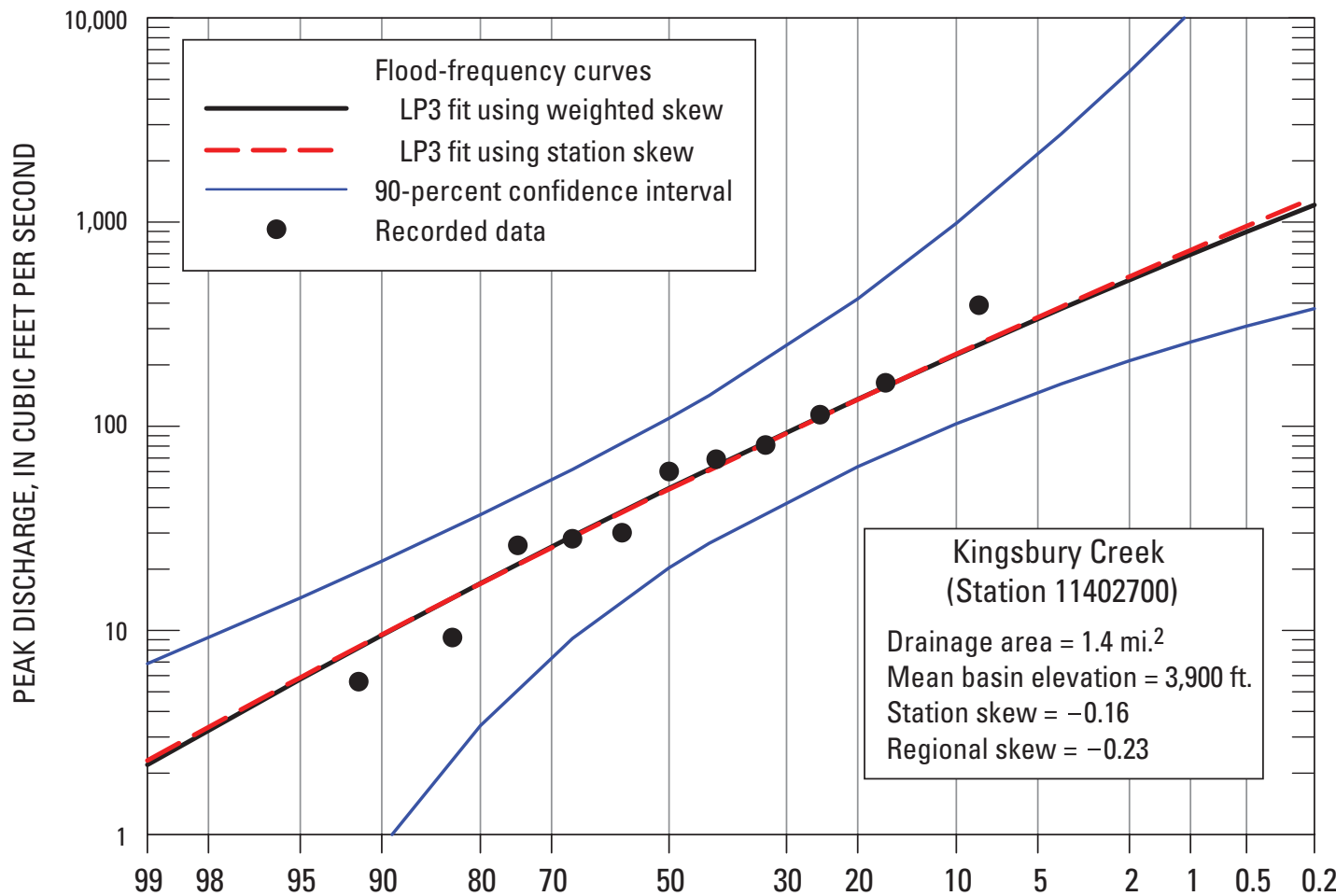

ANNUAL EXCEEDANCE PROBABILITY, IN PERCENT

Figure 8. Flood-frequency curves for Kingsbury Creek, California, (station 11402700) based on 11 years of recorded data with no censoring of annual-peak discharge. LP3, log Pearson Type 3; mi², square mile; ft, foot.

Flood-frequency curves in figure 9 are for a highelevation (mean basin elevation is $8,610 \mathrm{ft}$ ) station (West Walker River, station 10296500) that had censored data (an historical period with a perception threshold discharge equal to the largest recorded discharge in the systematic record). The largest recorded discharge plots above the fitted LP3 curves, but it is well within the relatively narrow 90 -percent confidence interval for the true distribution. The fitted curves based on station skew and weighted skew are almost identical for this site. Only three of the 81 recorded peak discharges at station 10296500 occurred during the winter-storm rainy season (generally November through March), but the two largest annual-peak discharges were winter-storm rainy season peaks (fig. 9). In contrast, almost all of the annual floods on Kingsbury Creek (station 11402700) were from the November-March period. Thus, figures 8 and $\underline{9}$ represent the shift from a low-elevation flood hydrology, dominated by winter rainfall events, to a high-elevation flood hydrology, dominated by snow-melt events with only a few-usually the largest—annual peaks resulting from winter rainfall.

Figure 9 generally represents sites where rain-snow interaction affected the annual-peak discharges. Winter-storm rain season peaks tend to be the largest recorded peaks at these sites, and the differences between the large rain peaks and the other peaks are large enough to result in positively skewed LP3 distributions. The differences between winter-storm season rain peaks and the other peaks may be so large that an LP3 distribution, limited by three parameters, cannot provide a reasonable fit to the data, and a mixed-population analysis may be the only way to reasonably determine flood frequency. 


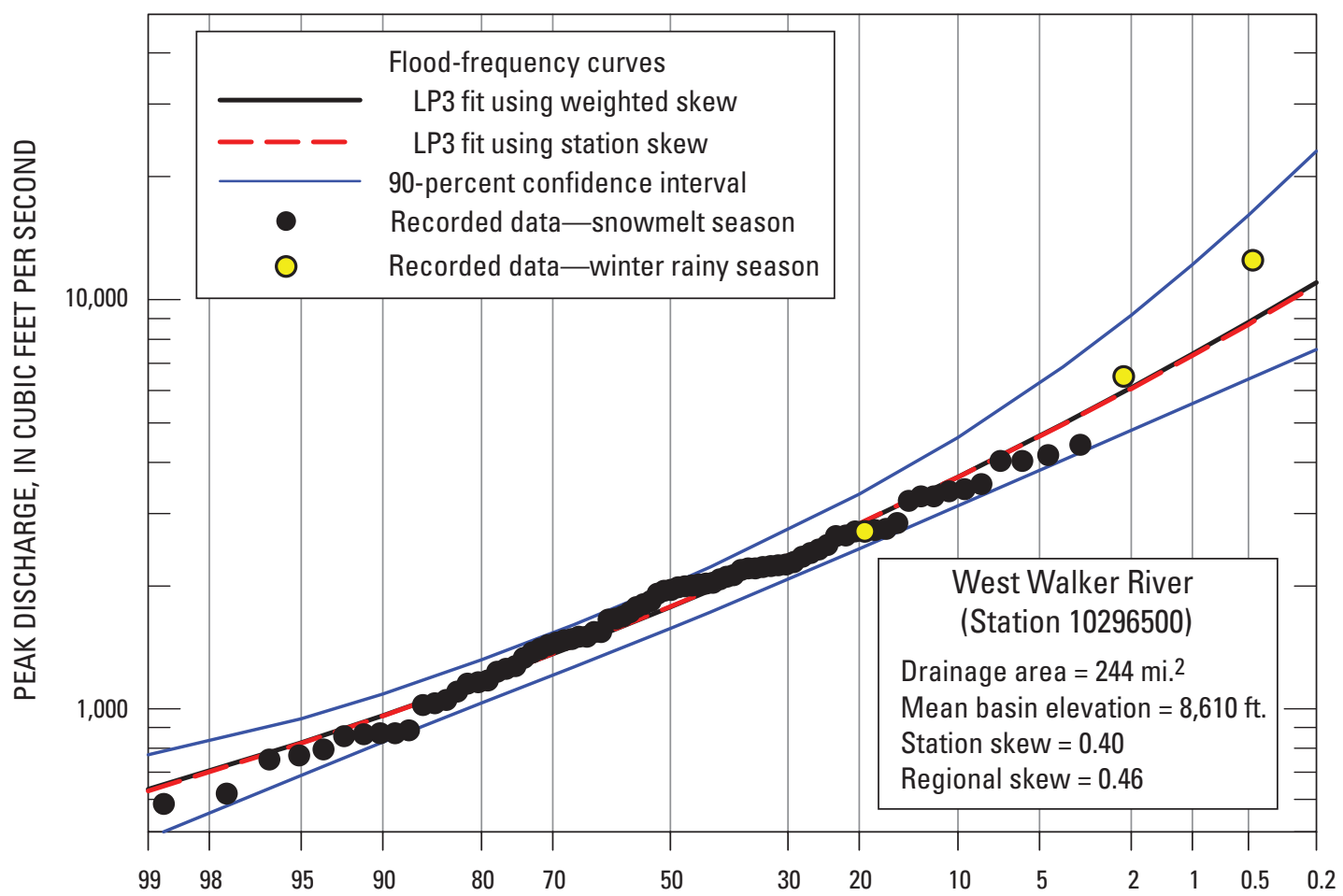

ANNUAL EXCEEDANCE PROBABILITY, IN PERCENT

Figure 9. Flood-frequency curves for West Walker River (station 10296500), California, based on 81 years of data recorded during an historical period of 106 years with a perception threshold discharge equal to the largest discharge during the 81-year record period. LP3, log Pearson Type 3; $\mathrm{mi}^{2}$, square mile; $\mathrm{ft}$, foot.

Figure 10 shows frequency curves for a site (Cantua Creek, developed regional skew function and applying the EMA station 11253310) that had heavily censored data (the complete lower tail consisting of 24 recorded peaks, including one zero value, were considered to be low outliers). While the frequency curves generally fit the upper tail of the data, the confidence intervals are especially wide owing to the large number of censored peaks.

The flood-frequency curve examples in figures 7 through 10 illustrate how well the LP3 distribution fit the recorded flood data for a variety of different record lengths, data-censoring for fitting the LP3 distribution provide reasonable estimates of flood frequency at gaged sites in the Sacramento-San Joaquin River Basin in California. Flood-frequency estimates at some higher-elevation sites might be improved by using a mixed-populations analysis. Although mixed-population analyses were beyond the scope of the current report, the flood-frequency study is ongoing in California and mixedpopulation analysis will be considered for some sites tied to poor-fitting LP3 frequency curves.

conditions, and mean basin elevations. Overall, using the newly 


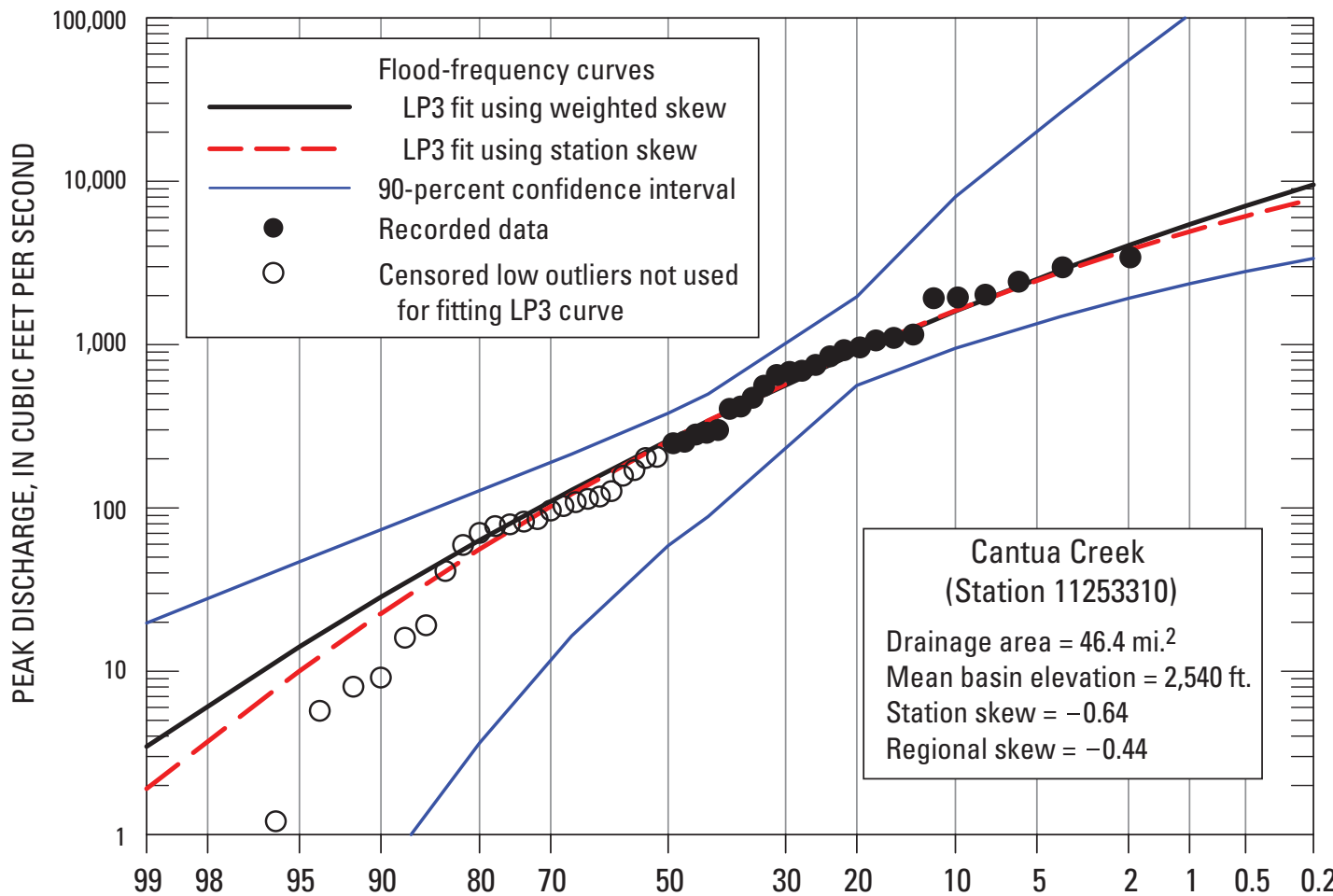

ANNUAL EXCEEDANCE PROBABILITY, IN PERCENT

Figure 10. Flood-frequency curves for Cantua Creek (station 11253310), California, based on 49 years of recorded data with all peaks smaller than the 50-percent exceedance probability censored as low outliers.

\section{Summary}

Reliable estimates of peak discharge for various exceedance probabilities, commonly referred to as floodfrequency estimates, are needed by engineers, land-use planners, resource managers, and scientists. Accordingly, the U.S. Geological Survey (USGS), in cooperation with the U.S. Forest Service, Federal Emergency Management Agency (FEMA), and the USGS Multi-Hazards Demonstration Project (MHDP), initiated a regional flood-frequency study for California in 2008. An important aspect of the comprehensive USGS flood-frequency study for California was developing new regional skew relations for California.

Because of the common interest and the need for updated flood-frequency information in the Sacramento and San Joaquin River Basin by the USGS and the U.S. Army Corps of Engineers (ACOE), both agencies developed a secondary cooperative program for estimating unregulated annualpeak discharge at 16 selected key dam sites in the basin and using these estimated discharges as part of the regional skew analysis. A method using maintenance of variance extension (MOVE) techniques was used to estimate annual-peak discharge at the key dam sites.
Annual-peak discharges on streams draining the Sierra Nevada almost always occur during the winter and spring (November through June) and result from a complex interaction of rain and snow. Rain is the predominant cause of peak discharge in basins that have mean elevations below about 4,000 ft, and the interaction of rain and snow increases with increasing elevation above that elevation. For basins that have mean elevations above about $8,000 \mathrm{ft}$, snowmelt is the predominant cause of peak discharges. The rain-snow interaction significantly affects regional skew in California.

To determine whether annual peak flow data indicate trends in California, 69 sites that were used in the regional skew analysis and had complete annual discharge records from 1977 to 2006 (30 years) were tested for monotonic trends using Kendall's tau, a non-parametric test for trends. The locations of the 69 sites represented the locations of all 158 sites used for the regional skew analysis. Of the 69 sites tested for trends in annual-peak discharge over the 30-year period, none had p-values less than or equal to 0.05 . On the basis of the trend-test results, monotonic trends in annual-peak discharge were not considered to be a factor in California and thus do not affect the interpretation or overall reliability of flood-frequency results. 
Flood-frequency estimates for gaged sites are computed by fitting a mathematical probability distribution to the series of annual-peak discharges. The LP3 distribution, which is the Pearson Type 3 distribution applied to the logarithms (base 10) of annual-peak discharge data, commonly is used to estimate flood frequency in the United States and was used for the current California study. The expected moment algorithm (EMA) was used for an initial LP3 frequency analysis in order to determine station skew for all sites used in the regional skew analysis, with an adjustment for zero flows, floods identified as low outliers, and historical flood information.

The California regional skew study was based on Bayesian regression procedures. To properly account for problems caused by large cross correlations among annualpeak discharges, a combination of Bayesian weighted least squares (WLS) and generalized least squares (GLS) regression was adopted to ensure that the regression model and the diagnostics for the regression would be reliable.

Various basin characteristics were considered as possible explanatory variables in the regression analysis for regional skew. The characteristic that best explained the site-to-site variability in skew was the mean basin elevation (ELEV). Three models were developed: (1) a constant skew denoted "Constant," (2) a model that used a linear relation between skew and mean basin elevation denoted "Elev," and (3) a model that used a nonlinear relation between skew and mean basin elevation denoted "NL-Elev." The average variance of prediction at a new site $\left(\mathrm{AVP}_{\text {new }}\right)$ corresponds to the mean square error (MSE) to describe the precision of the generalized skew. $\mathrm{AVP}_{\text {new }}$ was lowest for the NL-Elev model (0.14). Just as generalized skew varies from site-to-site depending upon mean basin elevation, so too do the values of variance of prediction at a new site, $\mathrm{VP}_{\text {new }}$. The NL-Elev regional skew model for California has $\mathrm{VP}_{\text {new }}$ values ranging from about 0.13 to 0.17 and effective record lengths between 52 years and 65 years, depending upon the value of mean basin elevation. $\mathrm{A} \mathrm{VP}_{\text {new }}$ between 0.13 and 0.17 is a marked improvement over the Bulletin 17B skew map, whose reported MSE is 0.302 with a corresponding effective record length of only 17 years.

Flood-frequency estimates for 158 sites used in the regional skew analysis and 206 additional sites in the Sacramento-San Joaquin River Basin were developed using the EMA program and applying the LP3 probability distribution with a weighted skew as described in Bulletin 17B to the annual-peak discharge data at the sites. Overall, using the newly developed regional skew function and applying the EMA program for fitting the LP3 distribution provide the best available estimates of flood frequency at gaged sites in the Sacramento-San Joaquin River Basin in California.

\section{References Cited}

Cohn, T.A., Lane, W.L., and Baier, W.G., 1997, An algorithm for computing moments-based flood quantile estimates when historical flood information is available: Water Resources Research, v. 39, no. 9, p. 2089-2096.

Cohn, T.A., Lane, W.L and Stedinger, J.R.,2001, Confidence intervals for EMA flood quantile estimates: Water Resources Research, v. 37, no. 6, p. 1695-1706 .

England, J.F., Jr., 1999, Draft user's manual for program EMA, at-site flood frequency analysis with historical/ paleohydrologic data: Bureau of Reclamation, $52 \mathrm{p}$.

England, J.F., Jr., Jarrett, R.D., and Salas, J.D., 2003a, Data-based comparisons of moments estimators that use historical and paleoflood data: Journal of Hydrology, v. 278, no. 1-4, p. 170-194.

England, J.F., Jr., Salas, J.D., and Jarrett, R.D., 2003b, Comparisons of two moments-based estimators that utilize historical and paleoflood data for the log-Pearson type III distribution: Water Resources Research, v. 39, no. 9, p. 1243, doi:10.1029/2002WR001791.

Feaster, T.D., Gotvald, A.J., and Weaver, J.C., 2009, Magnitude and frequency of rural floods in the southeastern United States, 2006: Volume 3, South Carolina: U.S. Geological Survey Scientific Investigations Report 20095156, 226 p.

Gotvald, A.J., Feaster, T.D., and Weaver, J.C., 2009, Magnitude and frequency of rural floods in the southeastern United States, 2006: Volume 1, Georgia: U.S. Geological Survey Scientific Investigations Report 2009-5043, 120 p.

Griffis, V.W. , Stedinger, J.R., and Cohn, T.A. , 2004, LP3 quantile estimators with regional skew information and low outlier adjustments: Water Resources Research, v. 40, W07503, doi:1029/2003WR002697, 17 p.

Griffis, V.W., and Stedinger, J.R., 2007, The use of GLS regression in regional hydrologic analyses: Journal of Hydrology, v. 344, p. 82-95.

Griffis, V.W., and Stedinger, J.R., 2009, Log-Pearson type 3 distribution and its application in flood frequency analysis, III: sample skew and weighted skew estimators: Journal of Hydrology, v. 14, no. 2, p. 121-130. 
Gruber, A.M., Reis, D.S., Jr., and Stedinger, J.R., 2007, Models of regional skew based on Bayesian GLS regression, Paper 40927-3285, in Kabbes, K.C., ed., World Environmental and Water Resources Congress 2007 Restoring our Natural Habitat, American Society of Civil Engineers, Tampa, Florida, May 15-19, 2007.

Gruber, A.M., and Stedinger, J.R., 2008, Models of LP3 regional skew, data selection, and Bayesian GLS regression, Paper 596, in Babcock, R., and Walton, R., eds., World Environmental \& Water Resources Congress 2008 Ahupua'a, American Society of Civil Engineers, Honolulu, Hawaii, May 12-16, 2008.

Helsel, D.R., and Hirsch, R.M., 1992, Statistical methods in water resources: New York, Elsevier, 522 p.

Hirsch, R.M., 1982, A comparison of four streamflow record extension techniques: Water Resources Research, v. 18, no. 4, p. 1081-1088.

Interagency Advisory Committee on Water Data, 1982, Guidelines for determining flood-flow frequency, Bulletin \#17B of the Hydrology Subcommittee: Office of Water Data Coordination, U.S. U.S. Geological Survey, 183 p. Available at http://water.usgs.gov/osw/bulletin17b/dl flow. pdf.

Martins, E.S., and Stedinger, J.R., 2002, Cross-correlation among estimators of shape: Water Resources Research, v. 38, no. 11, 7p.

Mount, J. F., 1995, California rivers and streams - The conflict between fluvial process and land use: University of California Press, p. 94-100.

Murphy, P.J., 2001, Evaluation of mixed-population flood frequency evaluation: Journal of Hydrologic Engineering, v. 6, p. 62-70.

Reis, D.S., Jr., Stedinger, J.R., and Martins, E.S., 2005, Bayesian generalized least squares regression with application to the log Pearson type III regional skew estimation: Water Resources Research, v. 41, W10419, doi:10.1029/2004WR003445, 14 p.
Ries, K.G., Guthrie, J.D., Rea, A.H., Steeves, P.A., and Stewart, D.W., 2008, Streamstats: A water resources web application: U.S. Geological Survey Fact Sheet 2008-3067, $6 \mathrm{p}$.

Stedinger, J.R., and Tasker, G.D., 1985, Regional hydrologic analysis-Ordinary, weighted and generalized least squares compared: Water Resources Research, v. 21, no. 9, p. 1421-1432. [with correction, Water Resources Research, v. 22, no. 5, p. 844,1986 .]

Tasker, G.D., and Stedinger, J.R., 1986, Regional skew with weighted LS regression: Journal of Water Resources Planning and Management, v.112, no. 2, p. 225-237.

Thomas, B.E., Hjalmarson, H.W., and Waltemeyer, S.D., 1997, Methods for estimating magnitude and frequency of floods in the southwestern United States: U.S. Geological Survey Water-Supply Paper 1997-2433, 205 p.

U.S. Army Corps of Engineers, 2002, Sacramento and San Joaquin River Basins comprehensive study: Technical studies documentation Appendix B - Synthetic hydrology technical documentation, accessed May 10, 2010, at http://www.compstudy.net/docs/techstudies/app b synthetichydrology 001.pdf.

Veilleux, A.G., 2009, Bayesian GLS regression for regionalization of hydrologic statistics, floods, and Bulletin 17B skew: Ithaca, New York, Cornell University, M.S. Thesis, August, $170 \mathrm{p}$.

Vogel, R.M., and J.R., Stedinger, 1985, Minimum variance streamflow record augmentation procedures: Water Resources Research, v. 21, no. 5, p. 715-723.

Waananen, A.O., and Crippen, J.R., 1977, Magnitude and frequency of floods in California: U.S. Geological Survey Water-Resources Investigations Report 77-21, 96 p..

Weaver, J.C., Feaster, T.D., and Gotvald, A.J., 2009, Magnitude and frequency of rural floods in the southeastern United States, 2006-Volume 2, North Carolina: U.S. Geological Survey Scientific Investigations Report 2009-5158, 113 p. Available at http://pubs.usgs.gov/ $\underline{\text { sir/2009/5158/. }}$ 
Table 1. Streamflow-gaging stations and statistical data used to analyze regional skew in California and to determine flood frequency for the Sacramento-San Joaquin River Basin, California.

Table 1 is available in a Microsoft ${ }^{\circ}$ Excel spreadsheet and can be accessed and downloaded at URL http://pubs.usgs.gov/ $\underline{\text { sir/2010/5260. }}$.

Table 2. Basin characteristics for analyzing regional skew in California.

\begin{abstract}
[A bbreviations: DRNAREA is the drainage area of the basin. BASINPERIM is the perimeter of the basin. DEM is digital elevation model. NHDPlus is the National Hydrography Dataset. RELIEF is the difference between the maximum and minimum elevations in the basin. ELEVMAX and ELEVMIN are the maximum and minimum elevations in the basin, respectively. LAKEAREA is the percentage of the basin drainage area covered by lakes and ponds. EL6000 is the percentage of the basin above 6,000 feet in elevation. OUTLETELEV is the basin elevation at the gage. RELRELF is the basin RELIEF divided by the BASINPERIM. DIST2COAST is the distance from the gage to the Pacific Ocean measured perpendicular to the eastern border of California. ELEV is the mean basin elevation. BSLDEM30 is the average basin slope computed from a 30-meter digital elevation model (DEM). FOREST is the percentage of the basin covered by forest. IMPERV is the percentage of the basin covered by impervious area. PRECIP is the basin averaged mean annual precipitation. PRISM is the Parameter-Elevation Regressions on Independent Slopes Model. JANMAX is the basin averaged January maximum temperature. JANMIN is the basin averaged January minimum temperature. LAT_CENT is the latitude of the basin centroid. LONG_CENT is the longitude of the basin centroid. $\mathrm{m}$, meter; >, greater than]
\end{abstract}

\begin{tabular}{|c|c|c|}
\hline Name & Description & Data source \\
\hline DRNAREA & Area, in square miles & $\begin{array}{l}\text { 30-m DEM, NHDPlus elev_cm grid http://www.horizon- } \\
\text { systems.com/NHDPlus/ }\end{array}$ \\
\hline BASINPERIM & Distance, in miles & $\begin{array}{l}\text { 30-m DEM, NHDPlus elev_cm grid http://www.horizon- } \\
\text { systems.com/NHDPlus/ }\end{array}$ \\
\hline RELIEF & Relief, in feet & $\begin{array}{l}\text { 30-m DEM, NHDPlus elev_cm grid http://www.horizon- } \\
\text { systems.com/NHDPlus/ }\end{array}$ \\
\hline ELEVMIN & Minimum elevation, in feet & $\begin{array}{l}\text { 30-m DEM, NHDPlus elev_cm grid http://www.horizon- } \\
\text { systems.com/NHDPlus/ }\end{array}$ \\
\hline LAKEAREA & Percentage of area covered by lakes and ponds & $\begin{array}{l}2001 \text { National Land Cover Database (NLCD) - Land } \\
\text { Cover http://www.mrlc.gov/nlcd multizone map.php }\end{array}$ \\
\hline EL6000 & $\begin{array}{l}\text { High Elevation Index - Percentage of area with elevation } \\
>6,000 \text { feet }\end{array}$ & $\begin{array}{l}\text { 30-m DEM, NHDPlus elev_cm grid http://www.horizon- } \\
\text { systems.com/NHDPlus/ }\end{array}$ \\
\hline RELRELF & Relative relief, in feet per mile & $\begin{array}{l}\text { 30-m DEM, NHDPlus elev_cm grid http://www.horizon- } \\
\text { systems.com/NHDPlus/ }\end{array}$ \\
\hline DIST2COAST & $\begin{array}{l}\text { Distance, in miles, from basin centroid to coast along a line } \\
\text { perpendicular to the eastern California border }\end{array}$ & $\begin{array}{l}\text { 30-m DEM, NHDPlus elev_cm grid http://www.horizon- } \\
\text { systems.com/NHDPlus/ }\end{array}$ \\
\hline ELEV & Average basin elevation, in feet & $\begin{array}{l}\text { 30-m DEM, NHDPlus elev_cm grid http://www.horizon- } \\
\text { systems.com/NHDPlus/ }\end{array}$ \\
\hline BSLDEM30M & Average basin slope, in percent & $\begin{array}{l}\text { 30-m DEM, NHDPlus elev_cm grid http://www.horizon- } \\
\text { systems.com/NHDPlus/ }\end{array}$ \\
\hline FOREST & Percentage of basin covered by forest & $\begin{array}{l}2001 \text { National Land Cover Database (NLCD) - Percent } \\
\text { Canopy http://www.mrlc.gov/nlcd multizone map.php }\end{array}$ \\
\hline JANMIN & Average minimum January temperature, in degrees Fahrenheit & $\begin{array}{l}\text { 800M resolution PRISM 1971-2000 data http://www. } \\
\text { prism.oregonstate.edu/products/ }\end{array}$ \\
\hline LONG_CENT & Longitude of the basin centroid, in degrees & $\begin{array}{l}\text { 30-m DEM, NHDPlus elev_cm grid http://www.horizon- } \\
\text { systems.com/NHDPlus/ }\end{array}$ \\
\hline LAT_CENT & Latitude of the basin centroid, in degrees & $\begin{array}{l}\text { 30-m DEM, NHDPlus elev_cm grid http://www.horizon- } \\
\text { systems.com/NHDPlus/ }\end{array}$ \\
\hline
\end{tabular}


Table 3. Basin characteristics for sites used in the regional skew analysis, California.

Table 3 is available in a Microsoft Excel spreadsheet and can be accessed and downloaded at URL http://pubs.usgs.gov/ $\underline{\operatorname{sir} / 2010 / 5260 .}$.

Table 4. Results of trend tests for annual peak discharge at selected sites in California.

\begin{tabular}{|c|c|c|c|c|}
\hline $\begin{array}{c}\text { Site } \\
\text { number }\end{array}$ & Station number & Station name & Kendall's tau & p-value \\
\hline 2 & 10296500 & West Walker River near Coleville, California & 0.20 & 0.12 \\
\hline 4 & 10336676 & Ward Creek at Hwy 89 near Tahoe Pines, California & 0.10 & 0.43 \\
\hline 6 & 10343500 & Sagehen Creek near Truckee, California & 0.03 & 0.86 \\
\hline 15 & 11015000 & Sweetwater River near Descanso, California & -0.17 & 0.20 \\
\hline 16 & 11028500 & Santa Maria Creek near Ramona, California & -0.16 & 0.21 \\
\hline 18 & 11042400 & Temecula Creek near Aguanga, California & -0.23 & 0.08 \\
\hline 20 & 11055500 & Plunge Creek near East Highlands, California & -0.12 & 0.35 \\
\hline 21 & 11055800 & City Creek near Highland, California & -0.03 & 0.84 \\
\hline 26 & 11075800 & Santiago Creek at Modjeska, California & -0.18 & 0.16 \\
\hline 29 & 11098000 & Arroyo Seco near Pasadena, California & -0.04 & 0.76 \\
\hline 42 & 11124500 & Santa Cruz Creek near Santa Ynez, California & 0.12 & 0.37 \\
\hline 44 & 11132500 & Salsipuedes Creek near Lompoc, California & 0.09 & 0.48 \\
\hline 47 & 11136800 & Cuyama River below Buckhorn Canyon near Santa Maria, California & -0.03 & 0.86 \\
\hline 51 & 11141280 & Lopez Creek near Arroyo Grande, California & 0.12 & 0.35 \\
\hline 52 & 11143000 & Big Sur River near Big Sur, California & 0.08 & 0.53 \\
\hline 53 & 11143200 & Carmel River at Robles del Rio, California & 0.10 & 0.46 \\
\hline 56 & 11147500 & Salinas River at Paso Robles, California & 0.10 & 0.46 \\
\hline 57 & 11148500 & Estrella River near Estrella, California & -0.11 & 0.38 \\
\hline 58 & 11148900 & Nacimiento River below Sapaque Creek near Bryson, California & 0.08 & 0.54 \\
\hline 59 & 11151300 & San Lorenzo Creek below Bitterwater Creek near King City, California & 0.05 & 0.72 \\
\hline 60 & 11152000 & Arroyo Seco near Soledad, California & 0.13 & 0.34 \\
\hline 62 & 11152600 & Gabilan Creek near Salinas, California & 0.17 & 0.20 \\
\hline 66 & 11159200 & Corralitos Creek at Freedom, California & 0.24 & 0.06 \\
\hline 67 & 11160000 & Soquel Creek at Soquel, California & 0.21 & 0.10 \\
\hline 68 & 11160500 & San Lorenzo River at Big Trees, California & 0.13 & 0.34 \\
\hline 69 & 11162500 & Pescadero Creek near Pescadero, California & 0.18 & 0.18 \\
\hline 71 & 11162630 & Pilarcitos Creek at Half Moon Bay, California & 0.13 & 0.34 \\
\hline 72 & 11164500 & San Francisquito Creek at Stanford University, California & 0.14 & 0.27 \\
\hline 73 & 11169500 & Saratoga Creek at Saratoga, California & 0.03 & 0.83 \\
\hline 75 & 11176400 & Arroyo Valle below Lang Canyon near Livermore, California & 0.11 & 0.41 \\
\hline 77 & 11182500 & San Ramon Creek at San Ramon, California & 0.07 & 0.59 \\
\hline 96 & 11200800 & Deer Creek near Fountain Springs, California & 0.08 & 0.53 \\
\hline 126 & 11224500 & Los Gatos Creek above Nunez Canyon near Coalinga, California & 0.00 & 1.00 \\
\hline 135 & 11237500 & Pitman Creek below Tamarack Creek, California & 0.05 & 0.69 \\
\hline 136 & 11242400 & North Fork Willow Creek near Sugar Pine, California & 0.00 & 0.99 \\
\hline 142 & 11253310 & Cantua Creek near Cantua Creek, California & -0.04 & 0.78 \\
\hline 164 & 11274500 & Orestimba Creek near Newman, California & 0.09 & 0.47 \\
\hline 165 & 11274630 & Del Puerto Creek near Patterson, California & 0.12 & 0.34 \\
\hline 175 & 11284400 & Big Creek above Whites Gulch near Groveland, California & 0.02 & 0.90 \\
\hline 185 & 11294500 & North Fork Stanislaus River near Avery, California & -0.07 & 0.58 \\
\hline 205 & 11316800 & Forest Creek near Wilseyville, California & 0.00 & 0.99 \\
\hline 206 & 11317000 & Middle Fork Mokelumne River at West Point, California & 0.06 & 0.67 \\
\hline 207 & 11318500 & South Fork Mokelumne River near West Point, California & 0.03 & 0.83 \\
\hline 226 & 11342000 & Sacramento River at Delta, California & 0.13 & 0.33 \\
\hline 231 & 11348500 & Pit River near Canby, California & 0.10 & 0.43 \\
\hline 251 & 11374000 & Cow Creek near Millville, California & 0.00 & 0.99 \\
\hline 256 & 11376000 & Cottonwood Creek near Cottonwood, California & 0.11 & 0.41 \\
\hline 267 & 11381500 & Mill Creek near Los Molinos, California & -0.04 & 0.79 \\
\hline 270 & 11383500 & Deer Creek near Vina, California & 0.04 & 0.75 \\
\hline 274 & 11390000 & Butte Creek near Chico, California & 0.10 & 0.45 \\
\hline
\end{tabular}


Table 4. Results of trend tests for annual peak discharge at selected sites in California.-Continued

\begin{tabular}{cclrr}
\hline $\begin{array}{c}\text { Site } \\
\text { number }\end{array}$ & Station number & \multicolumn{1}{c}{ Station name } & Kendall's tau & p-value \\
\hline 297 & 11402000 & Spanish Creek above Blackhawk Creek at Keddie, California & 0.05 & 0.71 \\
324 & 11427700 & Duncan Canyon Creek near French Meadows, California & 0.05 & 0.71 \\
325 & 11431800 & Pilot Creek above Stumpy Meadows Reservoir, California & 0.03 & 0.84 \\
332 & 11439500 & South Fork American River near Kyburz (river only), California & 0.02 & 0.90 \\
341 & 11449500 & Kelsey Creek near Kelseyville California & 0.14 & 0.29 \\
346 & 11461000 & Russian River near Ukiah, California & -0.02 & 0.89 \\
348 & 11468000 & Navarro River near Navarro, California & 0.07 & 0.59 \\
349 & 11468500 & Noyo River near Fort Bragg, California & 0.11 & 0.40 \\
350 & 11469000 & Mattole River near Petrolia, California & -0.02 & 0.89 \\
353 & 11475560 & Elder Creek near Branscomb, California & 0.15 & 0.26 \\
354 & 11476500 & South Fork Eel River near Miranda, California & -0.11 & 0.38 \\
355 & 11477000 & Eel River at Scotia, California & 0.06 & 0.63 \\
356 & 11478500 & Van Duzen River near Bridgeville, California & 0.18 & 0.18 \\
357 & 11481200 & Little River near Trinidad, California & 0.04 & 0.78 \\
359 & 11482500 & Redwood Creek at Orick, California & 0.09 & 0.49 \\
360 & 11519500 & Scott River near Fort Jones, California & -0.03 & 0.80 \\
362 & 11522500 & Salmon River at Somes Bar, California & -0.03 & 0.80 \\
363 & 11523200 & Trinity River above Coffee Creek near Trinity Center, California & 0.10 & 0.45 \\
365 & 11532500 & Smith River near Crescent City, California & 0.04 & 0.78 \\
\hline
\end{tabular}

Table 5. Key dam sites and drainage areas, periods of estimated unregulated annual-maximum-daily discharge, and periods of concurrent unregulated annual-maximum-daily and peak-discharge data.

[ACOE, U.S. Army Corps of Engineers; USGS, U.S. Geological Survey]

\section{Station number ${ }^{1} \quad$ Station name as shown in USGS or ACOE records}

11251099 San Joaquin River below Friant, California

11258099 Fresno River below Hidden Dam, California

11259099 Chowchilla River below Buchanan Dam, California

11270099 Merced River at Exchequer, California

11288099 Tuolumne River above La Grange Dam, California

11299599 Stanislaus River below Melones Dam, California

11308999 Calaveras River below New Hogan Dam, California

11335099 Cosumnes River at Michigan Bar, California

11344099 Littlejohns Creek below Farmington Reservoir, California ${ }^{2}$

11370599 Sacramento River at Keswick, California ${ }^{3}$

11388099 Stony Creek below Black Butte Dam, California

11407099 Feather River at Oroville, California

11413599 North Yuba River below Bullards Bar Dam, California

11446599 American River at Fair Oaks, California
11323599 Mokelumne River below Camanche Dam, California

\section{Drainage area (square mile)}

Period of estimated unregulated, annual-maximumdaily-discharge record

record

\begin{tabular}{|c|c|c|}
\hline 1,681 & 1896-1999 & $\begin{array}{c}1900-02,1904-07, \\
1909-50\end{array}$ \\
\hline 1,678 & 1911-99 & \\
\hline 258 & 1942-99 & $1942-75$ \\
\hline 235 & 1922-23, 1932-99 & 1932-72 \\
\hline 1,038 & 1902-14, 1916-99 & 1902-13, 1916-25 \\
\hline 1,532 & 1897-1999 & \\
\hline 904 & 1932-99 & \\
\hline 373 & 1964-98 & \\
\hline 628 & 1905-97 & 1905-28 \\
\hline 535 & 1908-97 & $1908-54$ \\
\hline 208 & 1951-99 & \\
\hline 6,468 & 1932-98 & $1932-43$ \\
\hline 742 & 1964-98 & \\
\hline 3,624 & 1902-97 & $1902-10$ \\
\hline 487 & 1941-66, 1970-97 & $1941-66$ \\
\hline 1,888 & 1905-98 & $1905-54$ \\
\hline
\end{tabular}

\footnotetext{
${ }^{1}$ Station number is the USGS station number with the last two digits (usually zeros) replaced by 99.

${ }^{2}$ All available flow data collected by ACOE.

${ }^{3}$ Peak-flow records available at this site from 1939-P. Peak-flow records from upstream site at Kennett (11369500 — drainage area $=6,355$ square miles) for 1926-1938 were also used at this site.
}

Period of concurrent unregulated annualmaximum-daily and peak-discharge record 1909-50 
Table 6. Unregulated, annual-maximum-daily discharge for key dam sites, California.

[Discharge is in cubic feet per second]

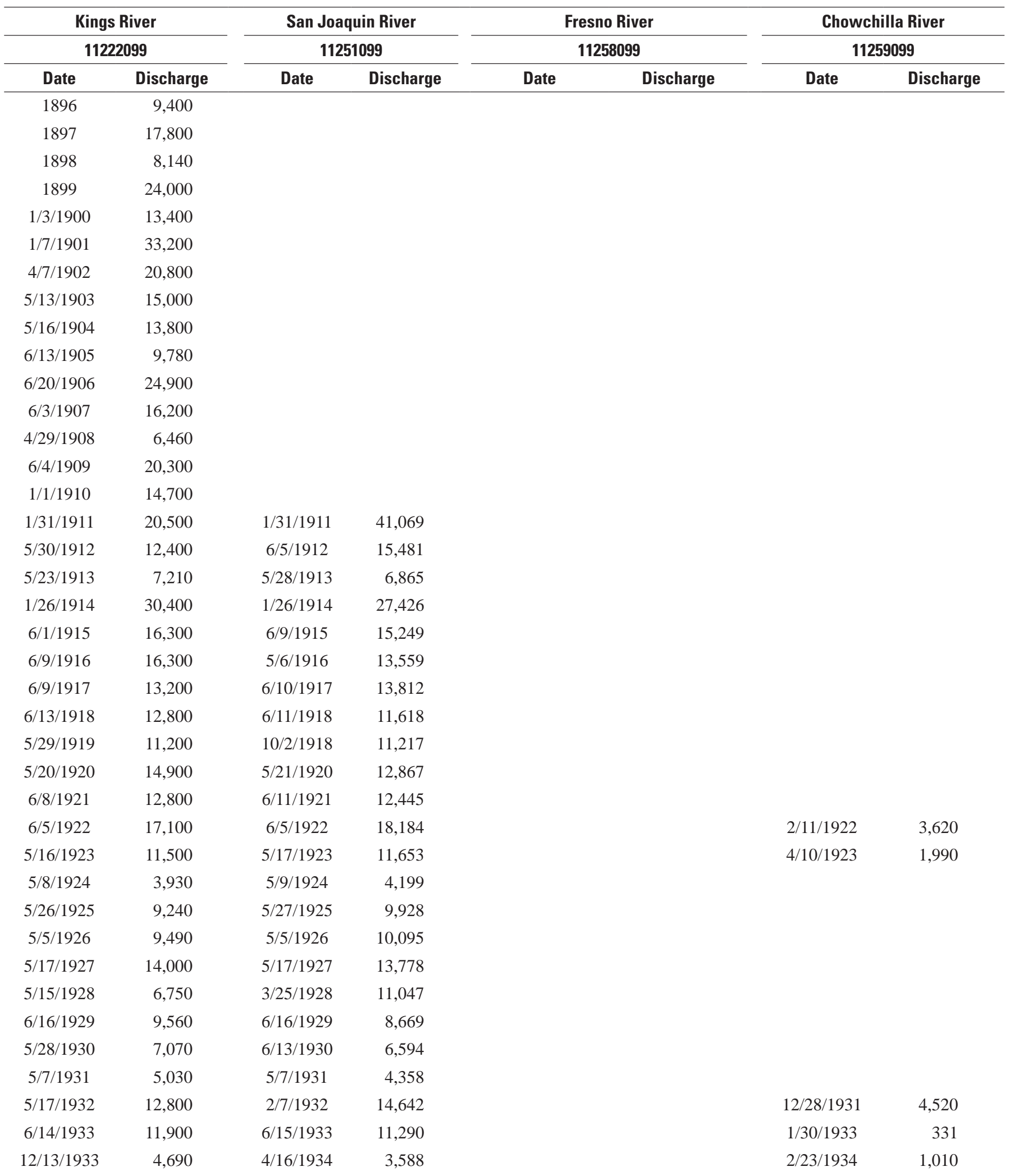


Table 6. Unregulated, annual-maximum-daily discharge or key dam sites, California.-Continued

[Discharge is in cubic feet per second]

\begin{tabular}{|c|c|c|c|c|c|c|c|}
\hline \multicolumn{2}{|c|}{ Kings River } & \multicolumn{2}{|c|}{ San Joaquin River } & \multicolumn{2}{|c|}{ Fresno River } & \multicolumn{2}{|c|}{ Chowchilla River } \\
\hline \multicolumn{2}{|c|}{11222099} & \multicolumn{2}{|c|}{11251099} & \multicolumn{2}{|c|}{11258099} & \multicolumn{2}{|c|}{11259099} \\
\hline Date & Discharge & Date & Discharge & Date & Discharge & Date & Discharge \\
\hline 6/4/1935 & 12,500 & 6/5/1935 & 13,637 & & & 4/8/1935 & 2,980 \\
\hline $5 / 14 / 1936$ & 11,600 & $5 / 14 / 1936$ & 10,690 & & & 2/23/1936 & 3,530 \\
\hline 2/6/1937 & 25,600 & 2/6/1937 & 18,639 & & & 2/6/1937 & 8,890 \\
\hline 12/11/1937 & 37,800 & 12/11/1937 & 40,497 & & & 2/11/1938 & 7,760 \\
\hline 4/22/1939 & 5,780 & 4/22/1939 & 5,341 & & & 3/10/1939 & 525 \\
\hline $5 / 15 / 1940$ & 12,000 & $5 / 13 / 1940$ & 11,205 & & & $1 / 26 / 1940$ & 3,340 \\
\hline 6/6/1941 & 15,300 & $5 / 24 / 1941$ & 16,145 & & & 2/12/1941 & 5,080 \\
\hline $5 / 25 / 1942$ & 14,000 & 5/26/1942 & 14,652 & 12/29/1941 & 1,680 & 12/29/1941 & 2,730 \\
\hline $1 / 22 / 1943$ & 16,200 & $1 / 22 / 1943$ & 17,074 & $1 / 22 / 1943$ & 2,300 & 3/10/1943 & 2,760 \\
\hline $5 / 9 / 1944$ & 8,490 & 5/9/1944 & 8,250 & 3/4/1944 & 1,190 & 3/4/1944 & 1,260 \\
\hline 2/2/1945 & 32,200 & 2/2/1945 & 34,376 & 2/2/1945 & 4,610 & 2/2/1945 & 5,200 \\
\hline 5/7/1946 & 11,600 & 5/7/1946 & 10,959 & 3/30/1946 & 1,840 & 3/30/1946 & 1,990 \\
\hline 5/6/1947 & 9,580 & 5/3/1947 & 8,716 & 12/27/1946 & 794 & 11/23/1946 & 649 \\
\hline 5/16/1948 & 10,400 & $5 / 27 / 1948$ & 10,615 & 4/10/1948 & 1,450 & 4/10/1948 & 2,490 \\
\hline 5/27/1949 & 9,240 & 5/27/1949 & 9,864 & 3/4/1949 & 942 & 3/4/1949 & 1,760 \\
\hline $5 / 31 / 1950$ & 10,500 & $5 / 31 / 1950$ & 10,664 & 2/6/1950 & 807 & 2/6/1950 & 1,720 \\
\hline 11/19/1950 & 51,600 & 11/19/1950 & 42,352 & 11/19/1950 & 5,130 & 11/19/1950 & 6,000 \\
\hline 6/6/1952 & 15,500 & 5/28/1952 & 18,149 & 1/25/1952 & 3,760 & 1/25/1952 & 4,950 \\
\hline 6/16/1953 & 7,390 & 4/27/1953 & 8,460 & 12/31/1952 & 819 & 1/14/1953 & 1,090 \\
\hline 5/19/1954 & 11,596 & 5/19/1954 & 10,744 & $1 / 25 / 1954$ & 455 & 2/14/1954 & 914 \\
\hline 6/8/1955 & 11,445 & 6/9/1955 & 11,572 & 5/8/1955 & 312 & 1/2/1955 & 448 \\
\hline $12 / 23 / 1955$ & 77,955 & 12/23/1955 & 74,984 & 12/23/1955 & 10,400 & 12/23/1955 & 18,400 \\
\hline 5/19/1957 & 14,493 & 5/19/1957 & 16,847 & 5/19/1957 & 672 & 2/25/1957 & 600 \\
\hline 6/19/1958 & 14,610 & 5/19/1958 & 17,541 & 4/3/1958 & 6,700 & 4/3/1958 & 7,250 \\
\hline 2/16/1959 & 5,663 & 2/16/1959 & 7,928 & 2/16/1959 & 630 & 2/16/1959 & 914 \\
\hline $5 / 12 / 1960$ & 5,076 & $5 / 12 / 1960$ & 6,612 & 2/9/1960 & 430 & $2 / 10 / 1960$ & 1,100 \\
\hline $5 / 24 / 1961$ & 3,350 & $5 / 24 / 1961$ & 3,850 & $12 / 2 / 1960$ & 122 & $12 / 2 / 1960$ & 122 \\
\hline 5/6/1962 & 12,746 & 2/10/1962 & 13,828 & 2/11/1962 & 4,430 & 2/10/1962 & 4,620 \\
\hline 2/1/1963 & 35,491 & 2/1/1963 & 40,982 & 2/1/1963 & 3,540 & 2/1/1963 & 4,190 \\
\hline 5/21/1964 & 7,152 & $5 / 20 / 1964$ & 6,655 & 11/21/1963 & 200 & 11/20/1963 & 397 \\
\hline $12 / 24 / 1964$ & 15,640 & 12/23/1964 & 25,531 & 12/23/1964 & 1,970 & $12 / 23 / 1964$ & 3,130 \\
\hline 5/6/1966 & 7,837 & 5/7/1966 & 7,445 & 12/30/1965 & 625 & 12/30/1965 & 1,400 \\
\hline 12/6/1966 & 71,711 & 12/6/1966 & 42,394 & 4/18/1967 & 4,030 & 12/6/1966 & 3,920 \\
\hline 5/29/1968 & 5,689 & 5/28/1968 & 5,454 & 2/21/1968 & 233 & 2/18/1968 & 207 \\
\hline 1/25/1969 & 48,816 & 1/25/1969 & 29,324 & 2/24/1969 & 7250 & 2/24/1969 & 7,010 \\
\hline 1/16/1970 & 16,166 & $1 / 16 / 1970$ & 15,961 & $1 / 16 / 1970$ & 2,330 & $1 / 16 / 1970$ & 4,230 \\
\hline $5 / 16 / 1971$ & 7,309 & 6/13/1971 & 8,583 & $12 / 2 / 1970$ & 252 & 12/22/1970 & 348 \\
\hline 6/7/1972 & 5,382 & 6/8/1972 & 7,122 & 12/26/1971 & 300 & 2/6/1972 & 367 \\
\hline 5/18/1973 & 17,501 & 5/18/1973 & 17,091 & 2/11/1973 & 4,500 & 2/11/1973 & 5,160 \\
\hline 6/7/1974 & 14,528 & 5/28/1974 & 13,622 & 4/2/1974 & 3,240 & $4 / 2 / 1974$ & 3,960 \\
\hline 6/1/1975 & 15,813 & 6/1/1975 & 16,941 & 3/26/1975 & 740 & 2/10/1975 & 1,320 \\
\hline
\end{tabular}


Table 6. Unregulated, annual-maximum-daily discharge or key dam sites, California._Continued

[Discharge is in cubic feet per second]

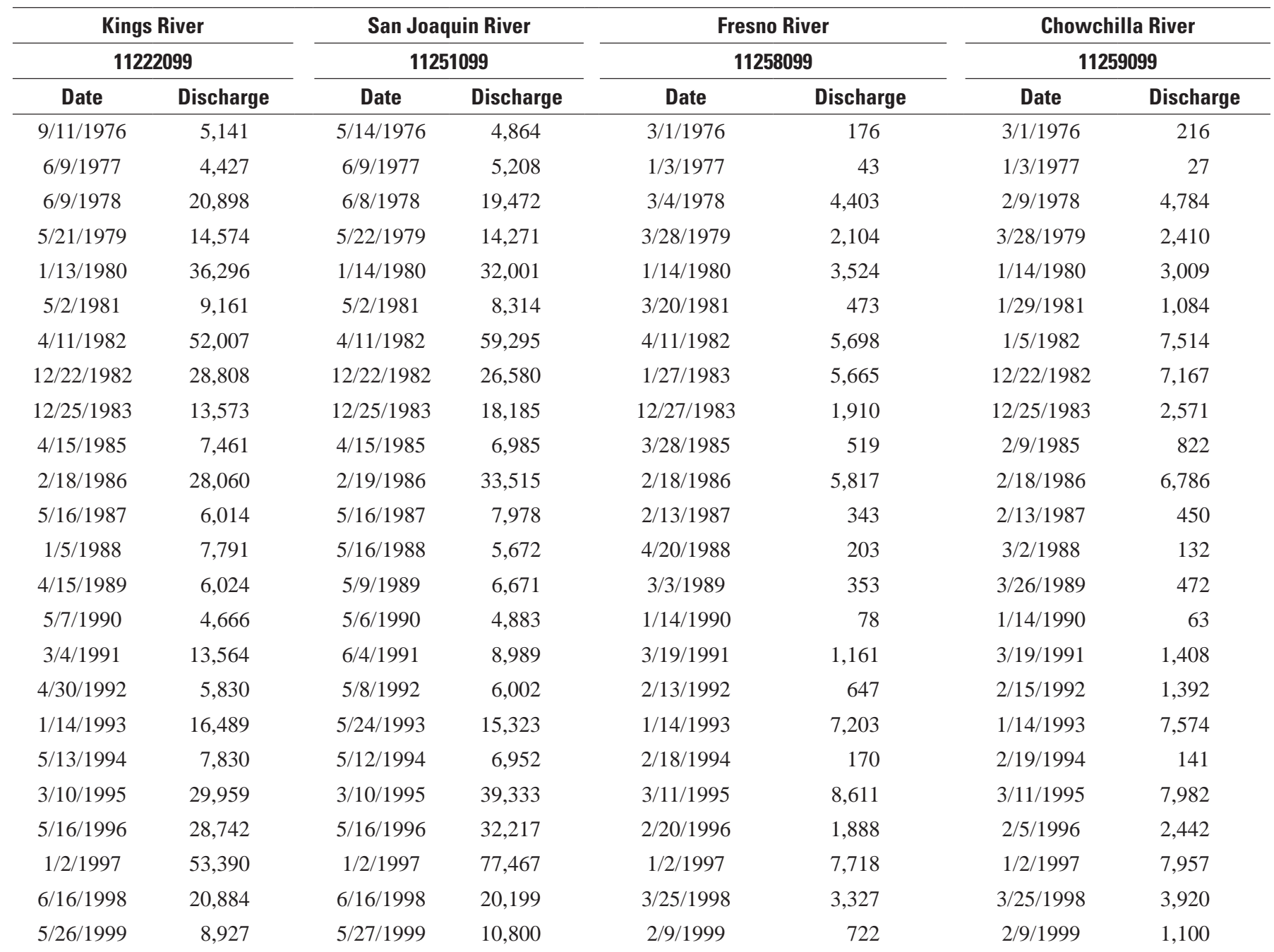


Table 6. Unregulated, annual-maximum-daily discharge for key dam sites, California._Continued

[Discharge is in cubic feet per second]

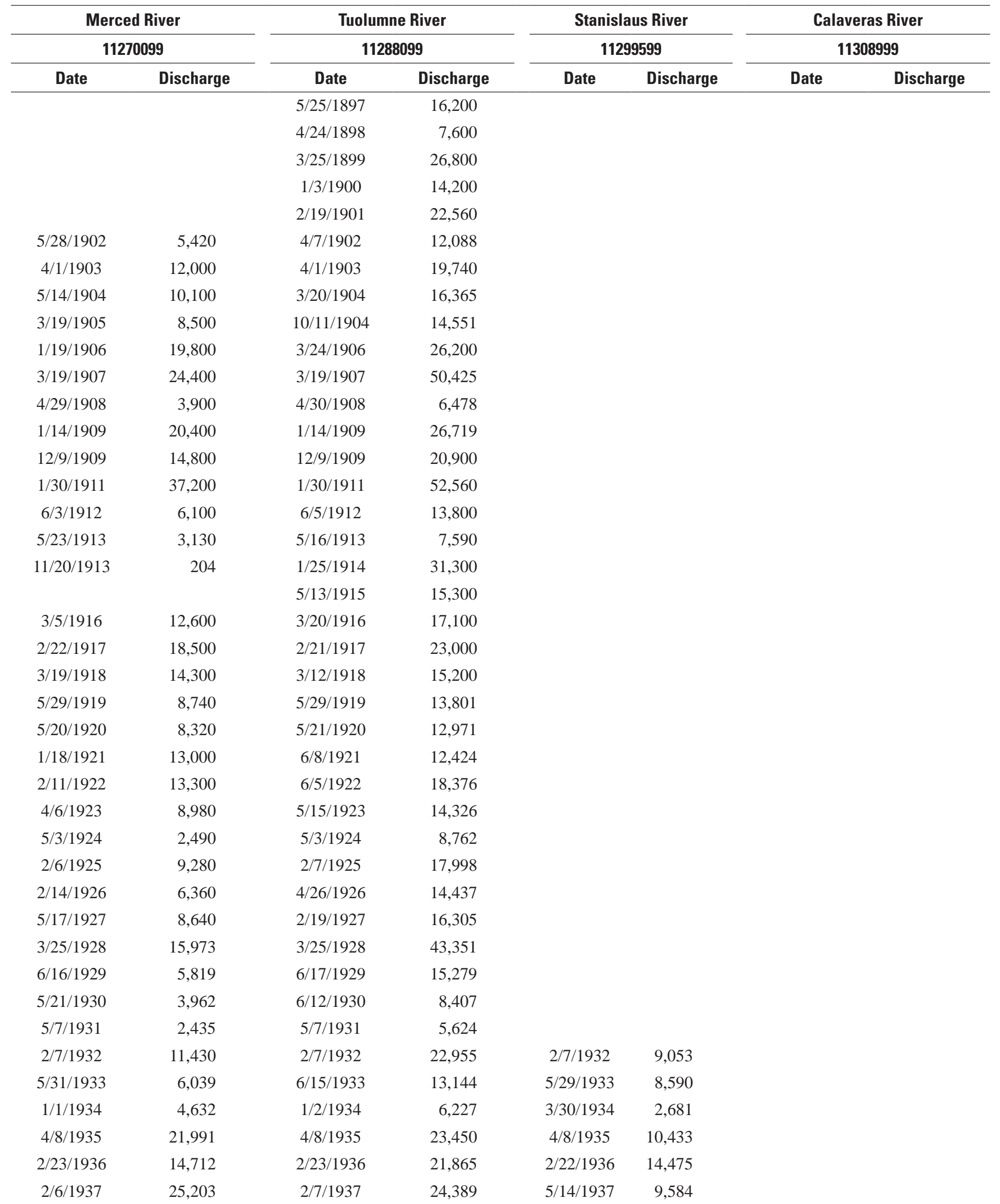


Table 6. Unregulated, annual-maximum-daily discharge for key dam sites, California.-Continued

[Discharge is in cubic feet per second]

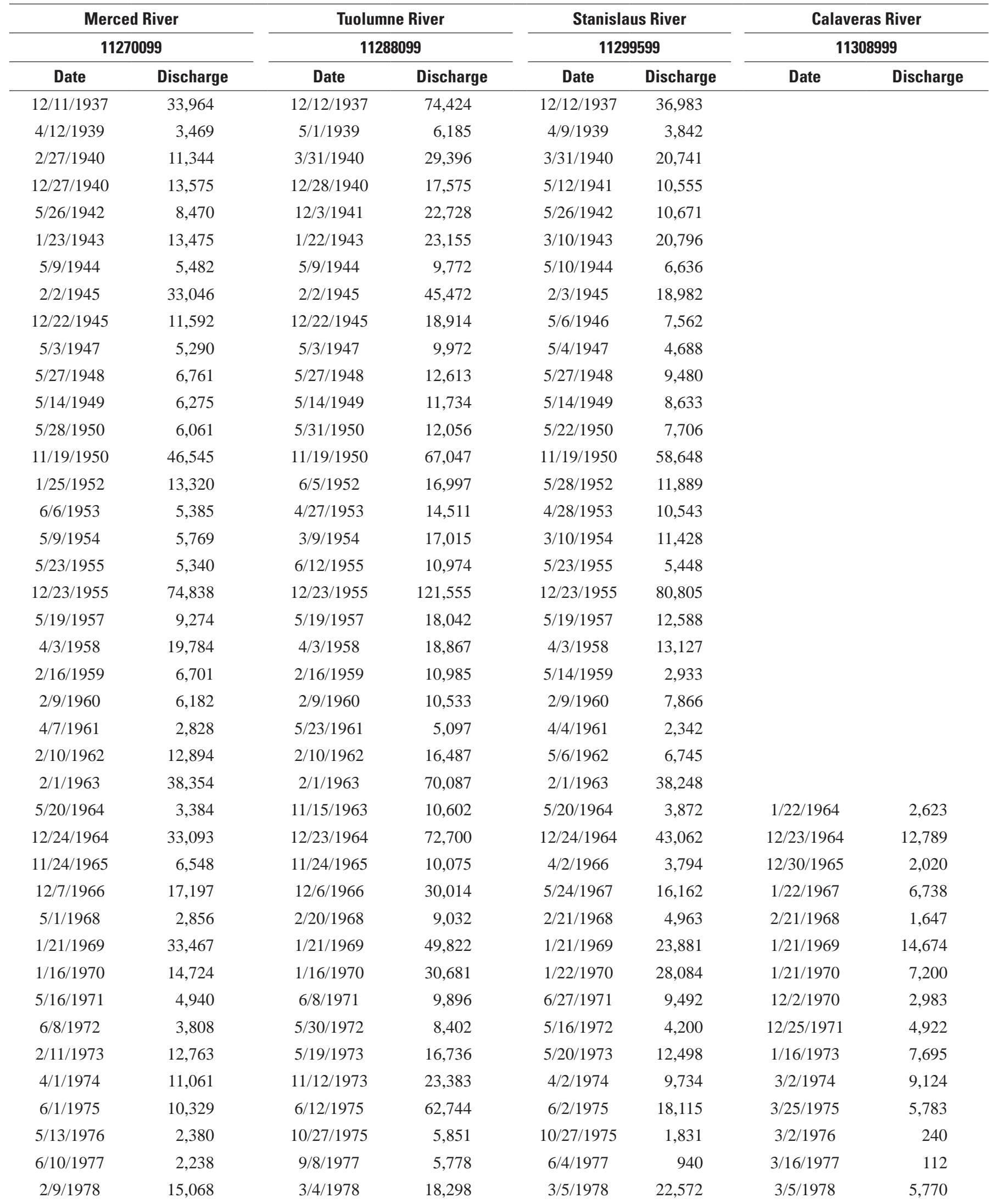


Table 6. Unregulated, annual-maximum-daily discharge for key dam sites, California.-Continued

[Discharge is in cubic feet per second]

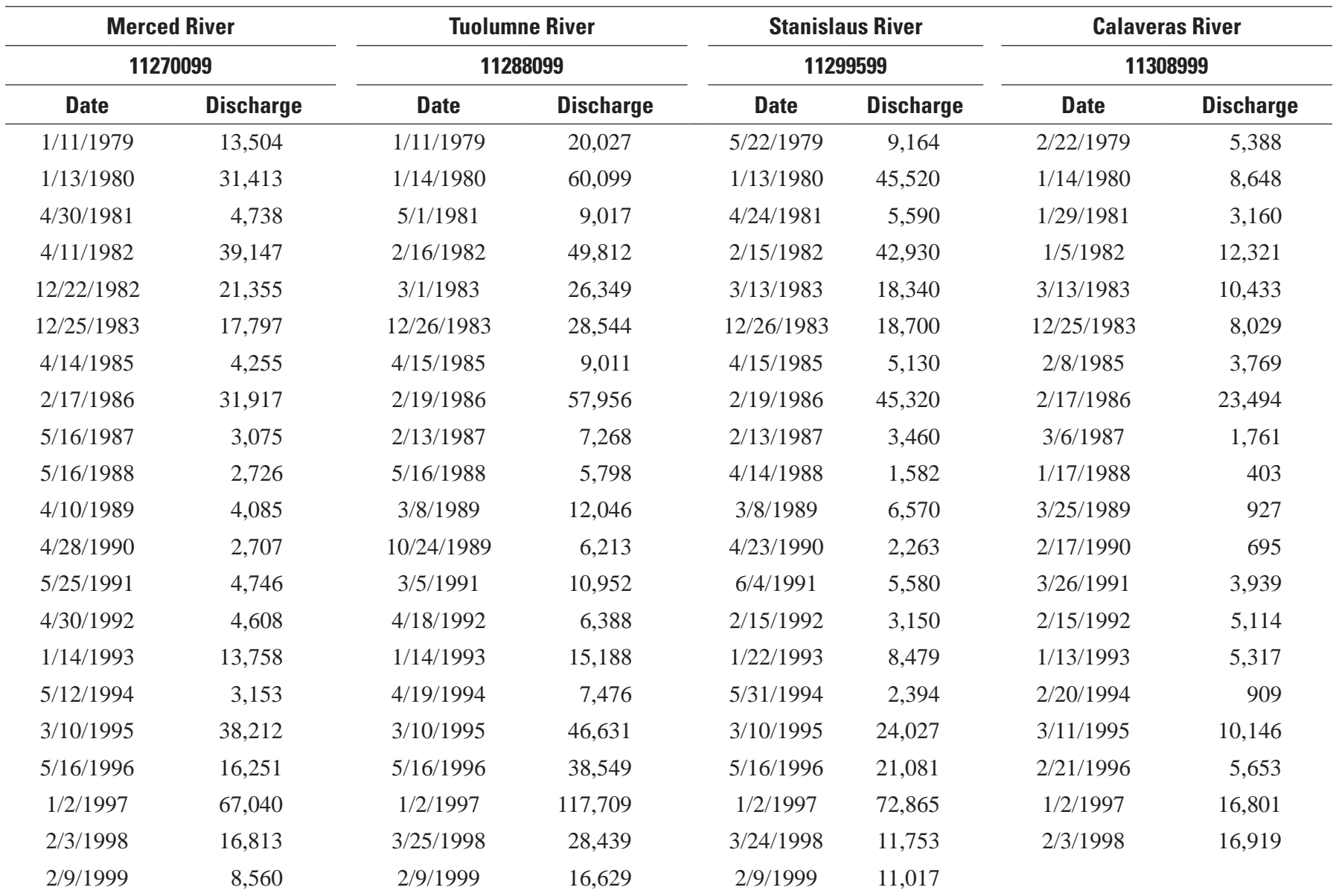


Table 6. Unregulated, annual-maximum-daily discharge for key dam sites, California.-Continued

[Discharge is in cubic feet per second]

\begin{tabular}{|c|c|c|c|c|c|c|c|}
\hline \multicolumn{2}{|c|}{ Mokelumne River } & \multicolumn{2}{|c|}{ Cosumnes River } & \multicolumn{2}{|c|}{ Little Johns Creek } & \multicolumn{2}{|c|}{ Sacramento River } \\
\hline \multicolumn{2}{|c|}{11323599} & \multicolumn{2}{|c|}{11335099} & \multicolumn{2}{|c|}{11344099} & \multicolumn{2}{|c|}{11370599} \\
\hline Date & Discharge & Date & Discharge & Date & Discharge & Date & Discharge \\
\hline $5 / 17 / 1905$ & 4,940 & & & & & & \\
\hline 6/12/1906 & 9,000 & & & & & & \\
\hline 3/19/1907 & 23,000 & & & & & & \\
\hline 4/30/1908 & 3,020 & $1 / 21 / 1908$ & 2,020 & & & & \\
\hline $1 / 14 / 1909$ & 12,600 & $1 / 14 / 1909$ & 20,800 & & & & \\
\hline 11/21/1909 & 7,200 & 3/21/1910 & 7,200 & & & & \\
\hline 1/30/1911 & 16,700 & 1/31/1911 & 22,400 & & & & \\
\hline 6/3/1912 & 4,920 & 3/7/1912 & 1,100 & & & & \\
\hline 5/18/1913 & 3,840 & 1/19/1913 & 1,220 & & & & \\
\hline $1 / 26 / 1914$ & 11,100 & $1 / 22 / 1914$ & 13,900 & & & & \\
\hline 6/1/1915 & 7,750 & 2/2/1915 & 5,920 & & & & \\
\hline 3/20/1916 & 8,040 & 3/20/1916 & 8,920 & & & & \\
\hline 6/10/1917 & 7,550 & 2/22/1917 & 13,500 & & & & \\
\hline 3/12/1918 & 6,940 & 3/12/1918 & 10,800 & & & & \\
\hline 2/11/1919 & 7,060 & 2/11/1919 & 13,100 & & & & \\
\hline $5 / 20 / 1920$ & 5,500 & 3/21/1920 & 3,210 & & & & \\
\hline 1/18/1921 & 7,350 & 1/18/1921 & 11,500 & & & & \\
\hline 6/3/1922 & 7,970 & 2/9/1922 & 7,970 & & & & \\
\hline $5 / 16 / 1923$ & 5,430 & $12 / 13 / 1922$ & 9,570 & & & & \\
\hline $5 / 2 / 1924$ & 1,770 & 2/8/1924 & 910 & & & & \\
\hline 2/6/1925 & 9,700 & 2/6/1925 & 15,200 & & & & \\
\hline 4/8/1926 & 3,100 & 2/12/1926 & 2,950 & & & & \\
\hline 5/17/1927 & 6,160 & 4/3/1927 & 8,630 & & & & \\
\hline 3/26/1928 & 20,300 & 3/25/1928 & 17,400 & & & & \\
\hline 6/16/1929 & 3,530 & 2/4/1929 & 2,800 & & & & \\
\hline $5 / 21 / 1930$ & 3,319 & 3/5/1930 & 4,360 & & & & \\
\hline 5/6/1931 & 2,022 & 2/19/1931 & 879 & & & & \\
\hline $5 / 14 / 1932$ & 5,616 & 2/6/1932 & 7,340 & & & 12/27/1931 & 34,921 \\
\hline 5/30/1933 & 5,105 & 5/30/1933 & 783 & & & 3/28/1933 & 19,476 \\
\hline 3/29/1934 & 2,858 & 1/1/1934 & 4,920 & & & 1/2/1934 & 24,437 \\
\hline 4/8/1935 & 6,214 & 4/8/1935 & 11,300 & & & 4/8/1935 & 44,755 \\
\hline 2/22/1936 & 15,034 & 2/22/1936 & 15,600 & & & 2/22/1936 & 53,145 \\
\hline 5/15/1937 & 6,194 & 2/6/1937 & 7,800 & & & 3/13/1937 & 29,107 \\
\hline $12 / 11 / 1937$ & 22,970 & 2/11/1938 & 15,500 & & & 12/11/1937 & 102,046 \\
\hline 4/8/1939 & 2,570 & 3/9/1939 & 1,500 & & & 3/13/1939 & 37,858 \\
\hline 3/31/1940 & 10,740 & 3/31/1940 & 16,700 & & & 2/28/1940 & 161,435 \\
\hline $5 / 12 / 1941$ & 6,214 & 3/2/1941 & 4,600 & & & 4/4/1941 & 71,408 \\
\hline 1/27/1942 & 10,397 & 1/27/1942 & 14,100 & & & 2/6/1942 & 79,872 \\
\hline 3/10/1943 & 11,380 & 3/10/1943 & 18,700 & & & 1/23/1943 & 44,393 \\
\hline 5/9/1944 & 3,964 & 3/4/1944 & 4,660 & & & 11/21/1943 & 6,771 \\
\hline 2/2/1945 & 12,891 & 2/2/1945 & 13,100 & & & 7/30/1945 & 9,519 \\
\hline
\end{tabular}


Table 6. Unregulated, annual-maximum-daily discharge for key dam sites, California.-Continued

[Discharge is in cubic feet per second]

\begin{tabular}{|c|c|c|c|c|c|c|c|}
\hline \multicolumn{2}{|c|}{ Mokelumne River } & \multicolumn{2}{|c|}{ Cosumnes River } & \multicolumn{2}{|c|}{ Little Johns Creek } & \multicolumn{2}{|c|}{ Sacramento River } \\
\hline \multicolumn{2}{|c|}{11323599} & \multicolumn{2}{|c|}{11335099} & \multicolumn{2}{|c|}{11344099} & \multicolumn{2}{|c|}{11370599} \\
\hline Date & Discharge & Date & Discharge & Date & Discharge & Date & Discharge \\
\hline 5/4/1947 & 4,046 & 3/10/1947 & 2,610 & & & 2/12/1947 & 33,936 \\
\hline $5 / 27 / 1948$ & 5,415 & 3/24/1948 & 3,140 & & & 1/7/1948 & 62,689 \\
\hline 11/21/1950 & 30,862 & 11/21/1950 & 16,700 & $12 / 8 / 1950$ & 5,284 & 10/29/1950 & 51,803 \\
\hline 5/28/1952 & 7,447 & 1/12/1952 & 8,300 & 3/15/1952 & 5,019 & $12 / 27 / 1951$ & 77,184 \\
\hline 4/27/1953 & 5,342 & 4/28/1953 & 2,630 & $1 / 14 / 1953$ & 725 & 1/9/1953 & 81,549 \\
\hline 3/10/1954 & 5,491 & 3/10/1954 & 3,020 & 3/17/1954 & 723 & $1 / 17 / 1954$ & 61,599 \\
\hline 4/3/1958 & 9,679 & 4/3/1958 & 20,090 & 4/3/1958 & 7,272 & 2/24/1958 & 83,075 \\
\hline 2/16/1959 & 2,719 & 2/17/1959 & 2,847 & 2/16/1959 & 1,419 & 1/12/1959 & 64,496 \\
\hline 2/8/1960 & 5,426 & 2/8/1960 & 6,833 & $2 / 10 / 1960$ & 1,402 & 2/8/1960 & 65,202 \\
\hline 5/23/1961 & 2,143 & 3/25/1961 & 470 & 2/2/1961 & 102 & 1/31/1961 & 43,389 \\
\hline 2/10/1962 & 5,241 & 2/15/1962 & 6,163 & 2/15/1962 & 5,086 & 2/13/1962 & 70,179 \\
\hline 2/1/1963 & 29,861 & 2/1/1963 & 27,560 & 2/13/1963 & 3,205 & $4 / 14 / 1963$ & 61,885 \\
\hline $5 / 15 / 1964$ & 3,321 & $1 / 22 / 1964$ & 2,959 & $1 / 22 / 1964$ & 898 & $1 / 20 / 1964$ & 62,888 \\
\hline 12/23/1964 & 36,173 & $12 / 23 / 1964$ & 29,883 & 12/26/1964 & 8,760 & $12 / 22 / 1964$ & 169,171 \\
\hline 5/7/1966 & 2,845 & 12/31/1965 & 1,999 & 1/30/1966 & 2,071 & 1/4/1966 & 37,155 \\
\hline 5/14/1972 & 3,818 & 12/25/1971 & 3,143 & 12/25/1971 & 1,267 & $1 / 22 / 1972$ & 38,269 \\
\hline 5/18/1973 & 5,987 & 1/12/1973 & 9,692 & 2/11/1973 & 5,368 & $1 / 16 / 1973$ & 74,532 \\
\hline 11/12/1973 & 7,905 & $3 / 2 / 1974$ & 6,657 & $3 / 2 / 1974$ & 4,749 & $1 / 16 / 1974$ & 190,847 \\
\hline 6/7/1975 & 6,733 & 3/25/1975 & 7,361 & 3/22/1975 & 2,742 & 3/19/1975 & 56,295 \\
\hline 10/27/1975 & 2,355 & 3/2/1976 & 347 & 9/11/1976 & 10 & 2/29/1976 & 22,709 \\
\hline 5/23/1977 & 1,122 & 2/23/1977 & 170 & 10/1/1976 & 0 & 9/29/1977 & 8,340 \\
\hline 5/15/1978 & 6,211 & 3/5/1978 & 6,472 & 2/9/1978 & 3,447 & 1/16/1978 & 95,610 \\
\hline 5/22/1979 & 6,292 & 3/1/1979 & 4,015 & 2/21/1979 & 5,080 & 2/13/1979 & 30,570 \\
\hline 1/13/1980 & 31,924 & $1 / 14 / 1980$ & 20,311 & $1 / 12 / 1980$ & 4,921 & 2/18/1980 & 89,540 \\
\hline 4/30/1981 & 4,873 & 3/26/1981 & 3,262 & 1/29/1981 & 3,890 & 1/28/1981 & 30,480 \\
\hline 4/11/1982 & 24,642 & 2/16/1982 & 25,608 & 3/31/1982 & 6,522 & 12/19/1981 & 81,790 \\
\hline 5/26/1983 & 12,304 & 3/13/1983 & 18,455 & 11/30/1982 & 6,620 & 3/13/1983 & 92,570 \\
\hline 12/25/1983 & 13,559 & 12/26/1983 & 14,218 & 12/25/1983 & 5,755 & 12/11/1983 & 66,160 \\
\hline 4/15/1985 & 3,766 & 2/8/1985 & 3,062 & 2/8/1985 & 2,411 & $11 / 12 / 1984$ & 23,980 \\
\hline 2/17/1986 & 27,878 & 2/17/1986 & 35,933 & 2/19/1986 & 9,555 & 2/17/1986 & 126,980 \\
\hline
\end{tabular}


Table 6. Unregulated, annual-maximum-daily discharge for key dam sites, California._Continued [Discharge is in cubic feet per second]

\begin{tabular}{|c|c|c|c|c|c|c|c|}
\hline \multicolumn{2}{|c|}{ Mokelumne River } & \multicolumn{2}{|c|}{ Cosumnes River } & \multicolumn{2}{|c|}{ Little Johns Creek } & \multicolumn{2}{|c|}{ Sacramento River } \\
\hline \multicolumn{2}{|c|}{11323599} & \multicolumn{2}{|c|}{11335099} & \multicolumn{2}{|c|}{11344099} & \multicolumn{2}{|c|}{11370599} \\
\hline Date & Discharge & Date & Discharge & Date & Discharge & Date & Discharge \\
\hline 4/30/1987 & 2,689 & $3 / 13 / 1987$ & 1,531 & $3 / 6 / 1987$ & 2,891 & 3/13/1987 & 39,673 \\
\hline 4/29/1988 & 2,255 & 1/17/1988 & 991 & 1/18/1988 & 63 & 12/6/1987 & 32,897 \\
\hline 3/8/1989 & 5,492 & 3/25/1989 & 5,839 & 3/4/1989 & 45 & 3/9/1989 & 72,974 \\
\hline 5/31/1990 & 2,273 & 3/5/1990 & 1,044 & 4/16/1990 & 25 & 5/27/1990 & 31,487 \\
\hline 6/4/1991 & 4,654 & 3/25/1991 & 3,631 & 3/26/1991 & 2,718 & 3/4/1991 & 28,971 \\
\hline 4/22/1992 & 3,298 & 2/15/1992 & 3,083 & 2/15/1992 & 4,517 & 2/20/1992 & 35,598 \\
\hline $5 / 17 / 1993$ & 6,262 & 1/21/1993 & 7,560 & 1/13/1993 & 2,697 & 3/17/1993 & 82,188 \\
\hline 5/11/1994 & 2,790 & 2/18/1994 & 929 & 2/20/1994 & 281 & $1 / 24 / 1994$ & 17,942 \\
\hline 5/1/1995 & 15,637 & 3/11/1995 & 18,236 & 1/27/1995 & 4,854 & 1/9/1995 & 111,630 \\
\hline 5/16/1996 & 18,015 & 3/5/1996 & 7,917 & 2/21/1996 & 3,941 & 2/21/1996 & 68,733 \\
\hline \multirow[t]{3}{*}{ 1/2/1997 } & 76,137 & 1/2/1997 & 61,822 & 1/2/1997 & 7,777 & 1/1/1997 & 215,623 \\
\hline & & & & 2/3/1998 & 11,270 & 2/3/1998 & 78,535 \\
\hline & & & & 2/9/1999 & 4,517 & & \\
\hline
\end{tabular}


Table 6. Unregulated, annual-maximum-daily discharge for key dam sites, California.—Continued

[Discharge is in cubic feet per second]

\begin{tabular}{|c|c|c|c|c|c|c|c|}
\hline \multicolumn{2}{|c|}{ Stony Creek } & \multicolumn{2}{|c|}{ Feather River } & \multicolumn{2}{|c|}{ North Yuba River } & \multicolumn{2}{|c|}{ American River } \\
\hline \multicolumn{2}{|l|}{11388099} & \multicolumn{2}{|l|}{11407099} & \multicolumn{2}{|l|}{11413599} & \multicolumn{2}{|l|}{11446599} \\
\hline Date & Discharge & Date & Discharge & Date & Discharge & Date & Discharge \\
\hline & & 3/30/1903 & 93,000 & & & & \\
\hline & & 2/24/1904 & 106,000 & & & & \\
\hline & & 3/19/1907 & 187,000 & & & 3/19/1907 & 105,000 \\
\hline & & $1 / 21 / 1908$ & 16,300 & & & $12 / 27 / 1907$ & 8,460 \\
\hline & & 1/16/1909 & 137,000 & & & $1 / 14 / 1909$ & 98,000 \\
\hline & & 12/9/1909 & 31,000 & & & $12 / 2 / 1909$ & 47,000 \\
\hline & & $12 / 31 / 1913$ & 88,110 & & & 1/1/1914 & 57,700 \\
\hline & & $5 / 11 / 1915$ & 69,049 & & & 5/12/1915 & 41,800 \\
\hline & & 3/20/1916 & 43,093 & & & 3/20/1916 & 33,200 \\
\hline & & 2/25/1917 & 73,106 & & & 2/25/1917 & 37,600 \\
\hline & & 3/26/1918 & 28,566 & & & 4/10/1918 & 12,400 \\
\hline & & 2/11/1919 & 46,335 & & & 2/11/1919 & 45,000 \\
\hline & & 4/16/1920 & 21,383 & & & 4/16/1920 & 18,800 \\
\hline & & $11 / 19 / 1920$ & 51,792 & & & $1 / 18 / 1921$ & 32,800 \\
\hline & & $5 / 20 / 1922$ & 35,090 & & & 5/18/1922 & 23,200 \\
\hline & & 3/26/1928 & 125,168 & & & 3/25/1928 & 119,000 \\
\hline & & 2/4/1929 & 12,046 & & & 2/4/1929 & 14,800 \\
\hline & & $12 / 15 / 1929$ & 77,702 & & & 3/5/1930 & 18,800 \\
\hline & & 3/19/1931 & 9,731 & & & 3/19/1931 & 7,920 \\
\hline & & 3/20/1932 & 18,570 & & & 2/7/1932 & 18,900 \\
\hline & & 5/31/1933 & 9,235 & & & 5/30/1933 & 12,700 \\
\hline & & 3/29/1934 & 16,971 & & & 1/2/1934 & 13,300 \\
\hline & & 4/8/1935 & 53,306 & & & 4/8/1935 & 49,300 \\
\hline & & 2/22/1936 & 57,064 & & & 2/22/1936 & 46,400 \\
\hline & & 4/15/1937 & 19,379 & & & 2/14/1937 & 22,500 \\
\hline & & 12/11/1937 & 158,984 & & & 12/11/1937 & 81,100 \\
\hline & & 3/27/1939 & 8,309 & & & 3/9/1939 & 8,500 \\
\hline & & 3/30/1940 & 134,761 & & & 3/30/1940 & 69,600 \\
\hline & & 2/11/1941 & 73,315 & 2/10/1941 & 14,400 & 2/11/1941 & 26,900 \\
\hline & & 2/6/1942 & 89,118 & 2/6/1942 & 21,800 & 1/27/1942 & 54,600 \\
\hline
\end{tabular}


Table 6. Unregulated, annual-maximum-daily discharge for key dam sites, California.—Continued

[Discharge is in cubic feet per second]

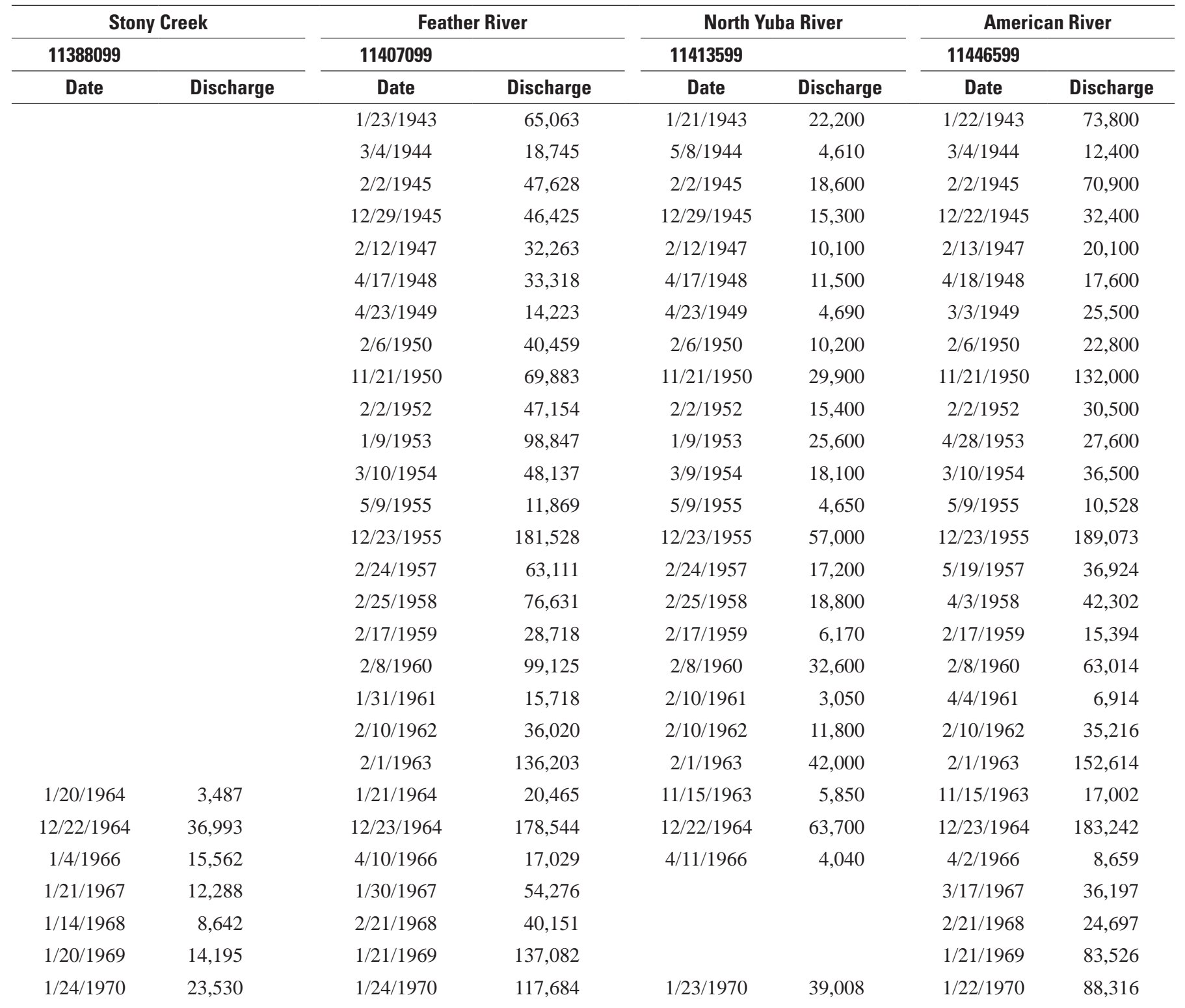


Table 6. Unregulated, annual-maximum-daily discharge for key dam sites, California.—Continued

[Discharge is in cubic feet per second]

\begin{tabular}{|c|c|c|c|c|c|c|c|}
\hline \multicolumn{2}{|c|}{ Stony Creek } & \multicolumn{2}{|c|}{ Feather River } & \multicolumn{2}{|c|}{ North Yuba River } & \multicolumn{2}{|c|}{ American River } \\
\hline 11388099 & & 11407099 & & 11413599 & & 11446599 & \\
\hline Date & Discharge & Date & Discharge & Date & Discharge & Date & Discharge \\
\hline 1/16/1971 & 12,177 & 3/26/1971 & 64,381 & 3/26/1971 & 14,839 & 3/26/1971 & 34,047 \\
\hline 1/23/1972 & 3,694 & 2/29/1972 & 19,994 & 1/23/1972 & 7,722 & 3/4/1972 & 10,046 \\
\hline 1/18/1973 & 12,304 & 1/16/1973 & 48,339 & 1/16/1973 & 13,955 & $1 / 12 / 1973$ & 49,291 \\
\hline 1/16/1974 & 26,751 & 3/30/1974 & 108,249 & 3/30/1974 & 25,317 & $1 / 17 / 1974$ & 40,631 \\
\hline 3/7/1975 & 10,523 & 2/13/1975 & 31,924 & 3/25/1975 & 11,352 & 3/25/1975 & 30,037 \\
\hline 2/27/1976 & 1,560 & 2/29/1976 & 12,079 & 2/29/1976 & 3,761 & 10/27/1975 & 10,389 \\
\hline 3/16/1977 & 376 & 2/21/1977 & 4,289 & 2/22/1977 & 1,234 & 6/10/1977 & 2,359 \\
\hline 1/16/1978 & 23,978 & 1/16/1978 & 54,954 & 1/15/1978 & 13,573 & 1/17/1978 & 31,169 \\
\hline 3/27/1979 & 6,164 & 2/14/1979 & 23,413 & 1/11/1979 & 7,203 & 1/12/1979 & 18,301 \\
\hline 1/13/1980 & 20,968 & 1/13/1980 & 137,623 & $1 / 13 / 1980$ & 54,716 & $1 / 14 / 1980$ & 124,915 \\
\hline 1/27/1981 & 9,586 & 2/14/1981 & 18,864 & 1/28/1981 & 6,519 & 3/26/1981 & 15,531 \\
\hline 12/19/1981 & 13,599 & 12/20/1981 & 98,900 & 12/20/1981 & 40,045 & 2/16/1982 & 113,126 \\
\hline 3/1/1983 & 30,136 & 3/13/1983 & 98,773 & 3/13/1983 & 29,853 & 3/13/1983 & 68,791 \\
\hline 12/25/1983 & 18,068 & $12 / 25 / 1983$ & 74,706 & 12/25/1983 & 24,655 & 12/26/1983 & 65,182 \\
\hline 2/8/1985 & 4,140 & 2/8/1985 & 17,547 & 2/8/1985 & 6,024 & 2/8/1985 & 13,473 \\
\hline 2/17/1986 & 36,446 & 2/17/1986 & 217,024 & 2/17/1986 & 69,649 & 2/18/1986 & 170,960 \\
\hline 3/13/1987 & 3,268 & 2/13/1987 & 30,978 & 2/13/1987 & 11,885 & 2/14/1987 & 11,690 \\
\hline $1 / 4 / 1988$ & 9,539 & 12/2/1987 & 18,756 & 12/10/1987 & 4,491 & 1/17/1988 & 5,447 \\
\hline 3/11/1989 & 4,376 & 3/10/1989 & 86,723 & 3/10/1989 & 23,377 & 3/25/1989 & 33,949 \\
\hline 1/13/1990 & 2,076 & 1/13/1990 & 14,726 & 5/31/1990 & 6,092 & 5/31/1990 & 7,606 \\
\hline 3/4/1991 & 7,080 & 3/4/1991 & 49,728 & 3/4/1991 & 21,656 & 3/5/1991 & 27,362 \\
\hline 2/12/1992 & 7,192 & 2/20/1992 & 24,208 & 2/20/1992 & 9,439 & 2/20/1992 & 13,266 \\
\hline 1/20/1993 & 21,429 & 3/18/1993 & 59,057 & 1/22/1993 & 14,230 & 1/22/1993 & 34,244 \\
\hline 2/7/1994 & 3,057 & 3/6/1994 & 9,457 & 12/8/1993 & 2,566 & $5 / 11 / 1994$ & 5,009 \\
\hline 1/9/1995 & 44,984 & 3/10/1995 & 134,188 & 1/14/1995 & 29,405 & 3/11/1995 & 68,260 \\
\hline 2/4/1996 & 9,981 & 2/5/1996 & 57,809 & 2/5/1996 & 21,784 & 5/16/1996 & 54,315 \\
\hline 1/1/1997 & 29,246 & 1/1/1997 & 312,893 & 1/1/1997 & 87,988 & 1/2/1997 & 252,431 \\
\hline 2/3/1998 & 29,811 & & & & & 2/3/1998 & 41,819 \\
\hline
\end{tabular}


Table 7. Regional skew models for California.

[Constant is the linear regression model with a constant skew. $\beta_{0}$ is the regression model constant, and $\beta_{1}$ and $\beta_{2}$ are regression model coefficients. $\sigma_{\delta}^{2}$ is the model error variance. ASEV is the average sampling error variance. $\mathrm{AVP}_{\text {new }}$ is the average variance of prediction for a new site. Pseudo $\mathrm{R}_{\delta}^{2}$ describes the fraction of the variability in the true skews explained by each model (Gruber and others, 2007). Standard deviations are in parentheses. Elev is the linear regression model relating skew to ELEV. NL-Elev is the non-linear model relating skew to ELEV. \%, percent]

\begin{tabular}{|c|c|c|c|c|c|c|c|c|}
\hline Model & Model equation & $\beta_{0}$ & $\beta_{1}$ & $\beta_{2}$ & $\sigma_{\delta}^{2}$ & ASEV & $\mathbf{A V P}_{\text {new }}$ & $\begin{array}{c}\text { Pseudo } \\
\boldsymbol{R}_{\delta}^{\mathbf{2}} \\
\end{array}$ \\
\hline Constant: & $\hat{\gamma}=\beta_{0}$ & $\begin{array}{l}-0.23 \\
(0.17)\end{array}$ & - & - & $\begin{array}{l}0.20 \\
(0.06)\end{array}$ & 0.03 & 0.23 & $0 \%$ \\
\hline Elev: & $\hat{\gamma}=\beta_{0}+\beta_{1}(\mathrm{ELEV})$ & $\begin{array}{l}-0.76 \\
(0.22)\end{array}$ & $\begin{array}{l}1.4 \mathrm{E}-04 \\
(3.4 \mathrm{E}-05)\end{array}$ & - & $\begin{array}{l}0.12 \\
(0.04)\end{array}$ & 0.03 & 0.15 & $41 \%$ \\
\hline NL-Elev: & $\hat{\gamma}=\beta_{0}+\beta_{2}\left\{1-\exp \left[-(\mathrm{ELEV} / 6,500)^{2}\right]\right\}$ & $\begin{array}{l}-0.62 \\
(0.19)\end{array}$ & - & $\begin{array}{c}1.3 \\
(0.31)\end{array}$ & $\begin{array}{l}0.10 \\
(0.04)\end{array}$ & 0.03 & 0.14 & $48 \%$ \\
\hline
\end{tabular}

Table 8. Average regional skew, variance of prediction $\left(V P_{\text {new }}\right)$ and equivalent record length (ERL) for nonlinear regional skew model NL-Elev for various values of mean basin elevation (ELEV), California.

\begin{tabular}{rccc}
\hline $\begin{array}{c}\text { Elevation, } \\
\text { in feet }\end{array}$ & $\begin{array}{c}\text { Average } \\
\text { regional } \\
\text { skew }\end{array}$ & VP $_{\text {new }}$ & ERL \\
\hline 0 & -0.62 & 0.14 & 65 \\
1,000 & -0.59 & 0.14 & 65 \\
2,000 & -0.50 & 0.14 & 62 \\
3,000 & -0.37 & 0.13 & 58 \\
4,000 & -0.21 & 0.13 & 55 \\
5,000 & -0.04 & 0.13 & 53 \\
6,000 & 0.13 & 0.14 & 52 \\
7,000 & 0.28 & 0.14 & 52 \\
8,000 & 0.40 & 0.15 & 53 \\
9,000 & 0.49 & 0.16 & 54 \\
10,000 & 0.56 & 0.16 & 55 \\
11,000 & 0.61 & 0.17 & 55 \\
\hline
\end{tabular}




\section{Glossary}

Annual Exceedance Probability The probability, often expressed as a decimal fraction less than 1.0, that an annual peak discharge will be exceeded in a 1-year period. Exceedance probabilities can be expressed in terms of their reciprocals as recurrence intervals or return periods in years.

Annual-Maximum-Daily Discharge The maximum daily mean discharge occurring during a water year.

Annual Peak The maximum instantaneous discharge occurring during a water year.

Basin Centroid The center of a basin area, which is represented by an irregular polygon. For irregularly shaped polygons, the centroid is derived mathematically and represents an approximate "center of gravity."

Bayesian Generalized Least Squares Regression (B-GLS) A form of GLS regression that uses a Bayesian statistical framework to estimate the regression model parameters and the model error variance and the precision of those estimators.

Effective Record Length (ERL) A representation of the precision of an estimator of a streamflow statistic, or in a regression analysis, the at-site variance of prediction. The effective record length represents the length of gaged record required to estimate a flow statistic at a site with the same accuracy as a regional regression for that region.

Mean Basin Elevation (ELEV) The area-weighted average height of the basin above a vertical datum, usually the North American Vertical Datum of 1988 (NAVD 88).

EL6000 The percentage of a basin that is more than 6,000 feet in elevation.

Expected Moments Algorithm (EMA) A method for fitting a probability distribution to annual peak-discharge data using a generalized method of moments that uses different types of censored data. The censored data often occur with historical information, where we have only limited knowledge about floods outside the period of systematic data collection at a gage. For example, we may have information that no floods have overtopped a road built near a gage 50 years before the gage was established. Censored data also may be in the form of interval discharges, where we know that an annual peak discharge was between some lower bound and some upper bound, such as zero and the smallest recordable discharge for a crest-stage gage.

Generalized Least Squares Regression (GLS) A regression method that accounts for differences in the variances and cross correlations of the errors associated with different recorded discharges. Differences in variances can result from differences in the length of record for each site, whereas cross correlations among concurrent annual peak discharges results in cross-correlation between estimated flood statistics, such as quantiles and skewness coefficients.
Historical Flood Information Information about the magnitude of flood flows, including recorded or estimated annual peak discharges, outside the systematic period of record.

Maintenance of Variation Extension (MOVE) A linear regression technique used for filling in missing streamflow data measurements or producing a unique extended streamflow sequence that maintains the mean and variance for the sample.

Mean Square Error (MSE) The average of the squares of the differences between the estimated values and the measured values. This metric represents how closely, on average, an estimated value matches a measured value. Of particular concern in this report is the MSE of of the regional skewness estimator.

Mixed Population Analysis A method for analyzing flood frequency at a site whose annual flood series is a mixture of two populations of flood discharges caused by different hydroclimatic events. In these situations, the frequency curve of annual events can best be described by computing separate curves for each type of event and then statistically combining the separate curves to derive a distribution applicable to the entire annual flood series.

Outlier A data point that departs from the trend of the rest of a data set as described by a distribution or other mathematical relationship.

Skewness Coefficient $(\gamma)$ A statistical measure of the lack of symmetry in a flood-frequency distribution. Station skew generally is computed from the logarithms of annual peak discharge at a streamflow-gaging station. Because station skew is sensitive to outliers, it may be an unreliable estimate of the true population skew, especially for small samples. For that reason, Bulletin 17B (Interagency Committee on Water Data, 1982) recommends that station skew be weighted with a regional, or generalized, skew that is based on data from many long-term stations to produce at-site flood-frequency estimates.

Standard Error (SE) A measure of the precision of an estimator, equal to the square root of the variance of the sampling error.

Variance of Prediction (VP) A measure of the likely difference between the prediction provided by a regression model and the actual value of the variable.

Variance of Prediction, new site (VPnew) A measure of the likely difference between the prediction provided by a regression model and the actual value of the variable for a new site that was not used to calibrate a model or estimate its parameters. 
Weighted Least Squares Regression (WLS) A regression method that accounts for the variation in the errors due to unequal record lengths at gaging stations used to estimate the flood characteristics of interest. WLS incorporates weights associated with each data point into the fitting criterion. The size of the weights corresponds to the precision of the information contained in the record.
100-Year Flood $\left(\mathbf{Q}_{100}\right)$ An annual peak discharge having an average recurrence interval of 100 years, corresponding to an annual exceedance probability of 0.01 . 


\section{Appendix A. Move Methods for Estimating Unregulated Annual-Peak-Flow Data at Key Dam Sites}

A method based on a linear relation between the logarithms of annual-peak discharge and the logarithms of annual-maximum-daily discharge was used to estimate unregulated, annual-peak discharge for the 16 key dam sites selected by the U.S. Army Corps of Engineers (ACOE). At ten sites, the log-linear relation was used to extend the period of unregulated annual-peak discharge record already available, and at six sites that had no unregulated annual-peak discharge record, a log-linear relation based on data from a nearby site was used to estimate unregulated annual-peak discharge values.

For streamflow record extension, a linear relation between concurrent flows or their logarithms is often used to estimate missing flow values or to extend the record at a short-record station using flow values at a site with a longer record. Hirsch (1982) showed that using simple ordinary least squares (OLS) regression estimators to extend a short record results in a variance for the extended record that is on average smaller than that for the short record. Because of this variance reduction problem, Hirsch (1982) developed maintenance of variance extension methods denoted type I (MOVE.1) and type II (MOVE.2) for extending a short record to preserve the expected variance of the flows at the short-record station. The MOVE. 1 procedure estimates the coefficients of the linear transformation for extending the short record using only the period of concurrent record, whereas MOVE. 2 uses the entire record at the long-record site to estimate the coefficients. Hirsch (1982) showed that the MOVE.2 method was slightly better and less biased than the simpler MOVE. 1 method. Vogel and Stedinger (1985) developed two additional MOVE methods (MOVE. 3 and MOVE.4), which also use information from both the shorter concurrent records and the longer record; MOVE. 3 and MOVE. 4 are intended to ensure that the original and generated flow values together have a sample mean and variance that are identical to the best estimates of the mean and the variance of the flows at the short-record site.

To estimate periods of unregulated annual-peak discharge record from concurrent periods of unregulated annual-maximum-daily discharge in this study, MOVE. 1 and MOVE. 3 were considered. The general equation for estimating missing values of discharge at a short-record site is

$$
Y_{i}=a+b\left(X_{i}-\bar{X}_{1}\right)
$$

where

$Y_{i}$ is the logarithm of estimated flow for year $i$ at the short-record site,

$a$ is the linear equation constant,

$b$ is the linear equation coefficient,

$X_{i}$ is the logarithm of flow for year $i$ at the long-record site, and

$\bar{X}_{1}$ is the mean of the logarithms of flow at the long-record site for the concurrent record (whose length is $n_{1}$ ).

The MOVE.1 equation for estimating missing data is

$$
Y_{i}=\bar{Y}_{1}+\frac{S_{Y_{1}}}{S_{X_{1}}}\left(X_{i}-\bar{X}_{1}\right),
$$

where

$\bar{Y}_{1}$ is the mean of the logarithms of flow values at the short-record site,

$S_{Y_{1}}$ is the standard deviation of the logarithms of flow values at the short-record site,

$\mathrm{S}_{\mathrm{X}_{1}}$ is the standard deviation of the logarithms of flow values at the long-record site for the period of concurrent record, and the other terms are as defined above.

Thus, for MOVE.1, the linear equation constant and coefficient in equation $\mathrm{A} 1$ can be written as

$$
\mathrm{a}=\bar{Y}_{1},
$$

and

$$
\mathrm{b}=\frac{\mathrm{S}_{\mathrm{Y}_{1}}}{\mathrm{~S}_{\mathrm{X}_{1}}}
$$

where all terms are defined as above. 
The MOVE.3 equation can be written in a form similar to the general linear equation A1 as follows:

$$
Y_{i}=a+b\left(X_{i}-\bar{X}_{2}\right)
$$

where $\bar{X}_{2}$ is the mean of the logarithms for the long-record site for the nonconcurrent record period (whose length is $\mathrm{n}_{2}$ ) and the other terms are as defined above. For MOVE.3 described by Vogel and Stedinger (1985), the estimates of the constant and the slope in equation A5 are

$$
a=\frac{\left(n_{1}+n_{2}\right) \hat{\mu}_{y}-n_{1} \bar{Y}_{1}}{n_{2}},
$$

and

$$
b^{2}=\frac{\left[\begin{array}{c}
\left(n_{1}+n_{2}-1\right) \hat{\sigma}_{y}{ }^{2}-\left(n_{1}-1\right) S_{Y_{1}}{ }^{2} \\
-n_{1}\left(\bar{Y}_{1}-\hat{\mu}_{y}\right)^{2}-n_{2}\left(a-\hat{\mu}_{y}\right)^{2}
\end{array}\right]}{\left(n_{2}-1\right) S_{X_{2}}{ }^{2}},
$$

where $\hat{\mu}_{\mathrm{y}}$ and $\hat{\sigma}_{\mathrm{y}}$ are the Matalas-Jacobs estimators of the mean and the variance at the short record site. The MatalasJacobs estimator for the mean is

$$
\hat{\mu}_{\mathrm{y}}=\bar{Y}_{1}+\frac{\mathrm{n}_{2}}{\mathrm{n}_{1}+\mathrm{n}_{2}} \widehat{\beta}\left(\overline{\mathrm{X}}_{2}-\overline{\mathrm{X}}_{1}\right)
$$

where $\bar{X}_{2}$ is defined above for $\mathrm{A} 5$ and $\widehat{\beta}$ is calculated from

$$
\widehat{\beta}=\frac{\sum_{\mathrm{i}=1}^{n_{1}}\left(X_{i}-\bar{X}_{1}\right)\left(Y_{i}-\bar{Y}_{1}\right)}{\sum_{i=1}^{n_{1}}\left(X_{i}-\bar{X}_{1}\right)^{2}} .
$$

The Matalas-Jacobs estimator for the variance is

$$
\begin{aligned}
& \hat{\sigma}_{\mathrm{y}}{ }^{2}=\frac{1}{\mathrm{n}_{1}+\mathrm{n}_{2}-1} \\
& \left\{\begin{array}{c}
\left(\mathrm{n}_{1}-1\right) \mathrm{S}_{\mathrm{y}_{1}}{ }^{2}+\left(\mathrm{n}_{2}-1\right) \hat{\beta}^{2} \mathrm{~S}_{\mathrm{x}_{2}}{ }^{2}+\left(\mathrm{n}_{2}-1\right) \alpha^{2}\left(1-\hat{\rho}^{2}\right) \mathrm{S}_{\mathrm{y}_{1}}{ }^{2} \\
+\frac{\mathrm{n}_{1} \mathrm{n}_{2}}{\left(\mathrm{n}_{1}+\mathrm{n}_{2}\right)} \hat{\beta}^{2}\left(\overline{\mathrm{X}}_{2}-\overline{\mathrm{X}}_{1}\right)^{2}
\end{array}\right\},
\end{aligned}
$$

where

$$
\alpha^{2}=\frac{n_{2}\left(n_{1}-4\right)\left(n_{1}-1\right)}{\left(n_{2}-1\right)\left(n_{1}-3\right)\left(n_{1}-2\right)},
$$

and

$$
\hat{\rho}=\widehat{\beta} \frac{S_{X_{1}}}{S_{Y_{1}}} .
$$

To determine whether the simpler MOVE. 1 method would produce peak flow estimates that are as reliable as those produced from the MOVE. 3 method, the two procedures were compared using data from stations that had long concurrent records of both annual-peak and annual-maximum-daily discharge. The four selected sites, in the Sacramento-San Joaquin River Basin, are listed in table A1 along with their concurrent record lengths and the Pearson cross-correlation between the logs of annual-peak discharge and annualmaximum-daily discharge. For each site, six samples of a 10 -year short record period $\left(n_{s 1}\right)$ were selected and assumed to be the only concurrent records available.

The complete record periods available $\left(n_{1}+n_{2}\right)$ varied from 76 to 95 years (table A1); for each sample, $n_{s 1}=10$ and $n_{s 2}$ varied from 66 to 85 years. The six 10 -year samples of concurrent record at each site were determined by using (1) the first 10 years of actual concurrent record, (2) the second 10 years of actual concurrent record, (3) the third 10 years of actual concurrent record, (4) the last 10 years of actual concurrent record, (5) the next to last 10 years of actual concurrent record, and (6) the third to last 10 years of actual concurrent record. For each sample at each site, the MOVE.1 and MOVE. 3 methods were used to estimate annual-peak discharges for the $\mathrm{n}_{\mathrm{s} 2}$ years assumed to have no actual peakdischarge record. The means and the standard deviations of the logarithms of the annual-peak discharge for the complete record period ( $n_{s 2}$ years of estimated peak discharge plus $n_{s 1}$ $=10$ years of concurrent and recorded peak discharge) were then compared with the means and the standard deviations of the logarithms of the actual recorded peak discharge for the complete record period. The results of the comparisons of the 6 samples from each of the 4 test sites (24 comparisons) are shown as box plots in figure A1. The box plots indicate that both MOVE. 1 and MOVE.3 produced estimated means that were slightly biased on the low side for the 24 replicates (median log residuals less than zero and the vertical boxes centered below zero). Both methods produced estimates of standard deviation with little or no bias (median log residuals were very close to zero, and the vertical boxes were centered near zero. Differences between MOVE. 1 and MOVE. 3 were negligible for both the mean and the standard deviation.

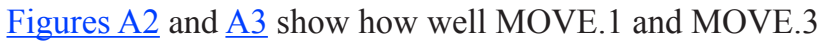
functioned for each of the 24 samples. Figure A2 shows the residual from the actual mean for each sample for both methods, and figure A3 shows the residual from the actual standard deviation for each sample. Both MOVE methods produced positive and negative residuals for the same samples, and the differences between the MOVE. 1 and the MOVE. 3 residuals for each sample were very small. On the basis of these results, the simpler MOVE.1 method was adopted to estimate annual-peak discharge from annual-maximumdaily discharge in California. Thus, the MOVE.1 method was used for the ten sites that had some concurrent records of unregulated annual-peak discharge and annual-dailymaximum discharge before dam construction. 
Table A1. Four long-record sites used to test MOVE.1 and MOVE.3 methods in the Sacramento-San Joaquin River Basin, California.

\begin{tabular}{lllcc}
\hline $\begin{array}{c}\text { Station } \\
\text { number }\end{array}$ & \multicolumn{1}{c}{$\begin{array}{c}\text { Abbreviated names } \\
\text { of stations }\end{array}$} & $\begin{array}{c}\text { Period of concurrent } \\
\text { annual maximum- } \\
\text { daily and peak } \\
\text { discharge record }\end{array}$ & $\begin{array}{c}\text { Number of years of } \\
\text { concurrent record } \\
\left(\boldsymbol{n}_{\mathbf{1}}+\boldsymbol{n}_{\mathbf{2}}\right)\end{array}$ & $\begin{array}{c}\text { Pearson correlation } \\
\text { coefficient }(\boldsymbol{r}) \text { relating } \\
\text { concurrent annual } \\
\text { maximum-daily discharge } \\
\text { and peak discharge }\end{array}$ \\
\hline 11230500 & Bear Creek near Lake Thomas & $1922-88,1992-2006$ & 82 & 0.96 \\
11317000 & MF Mokelumne River at West Point & $1912-2006$ & 95 & 0.98 \\
11338500 & Deer Creek near Vina & $1913-15,1921-2006$ & 89 & 0.95 \\
11390000 & Butte Creek near Chico & $1931-2006$ & 76 & 0.98 \\
\hline
\end{tabular}

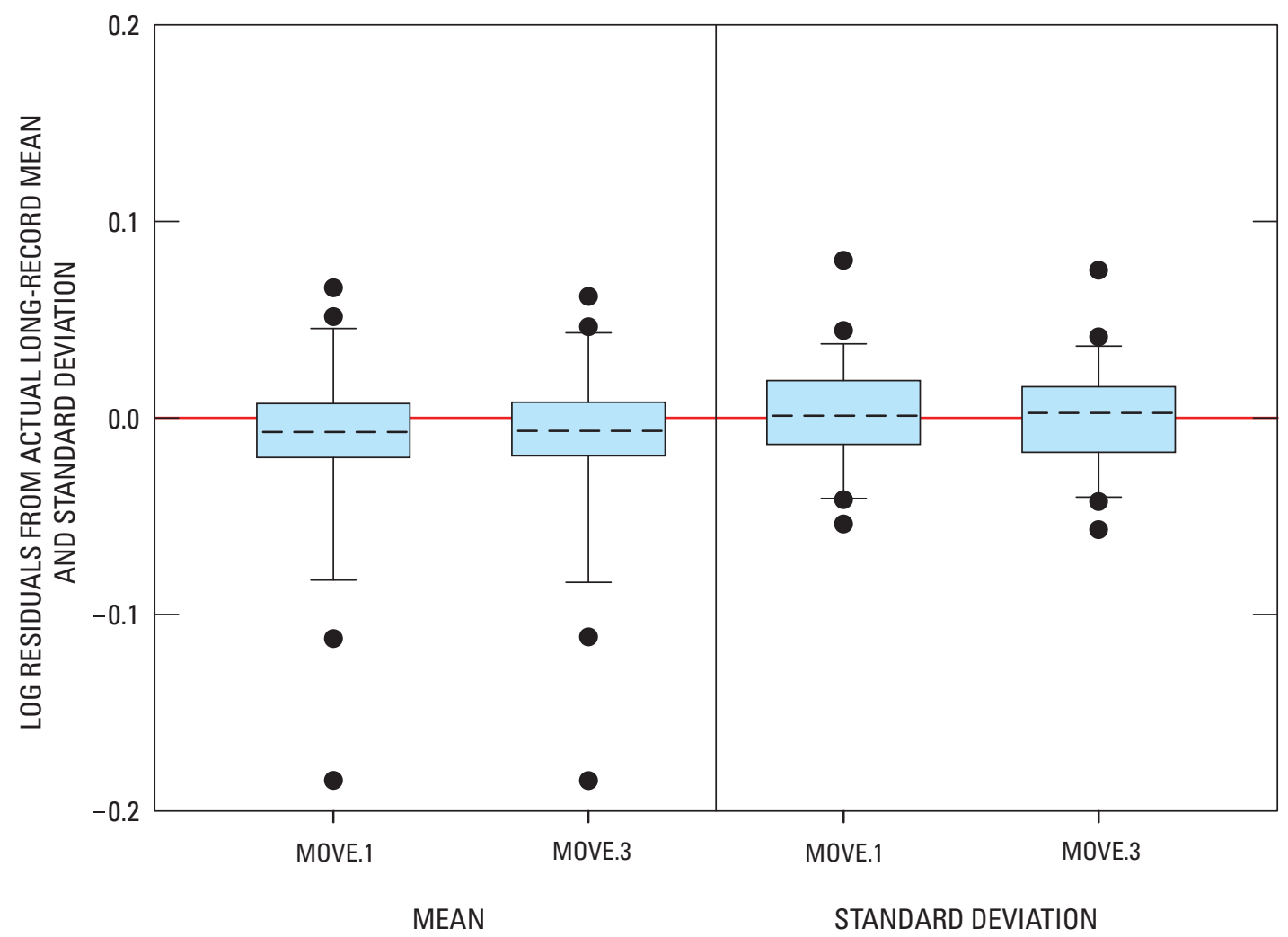

\section{EXPLANATION}

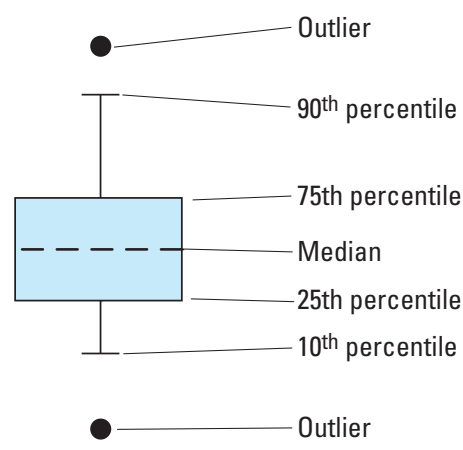

Figure A1. Comparing the MOVE.1 method with the MOVE.3 method to estimate the mean and standard deviations of the logs of annual-peak discharges from the logs of annual-maximum-daily discharge based on data from four sites (24 samples) in California. Each sample had a short, concurrent record of 10 years and an estimation period varying from 66 to 85 years. 


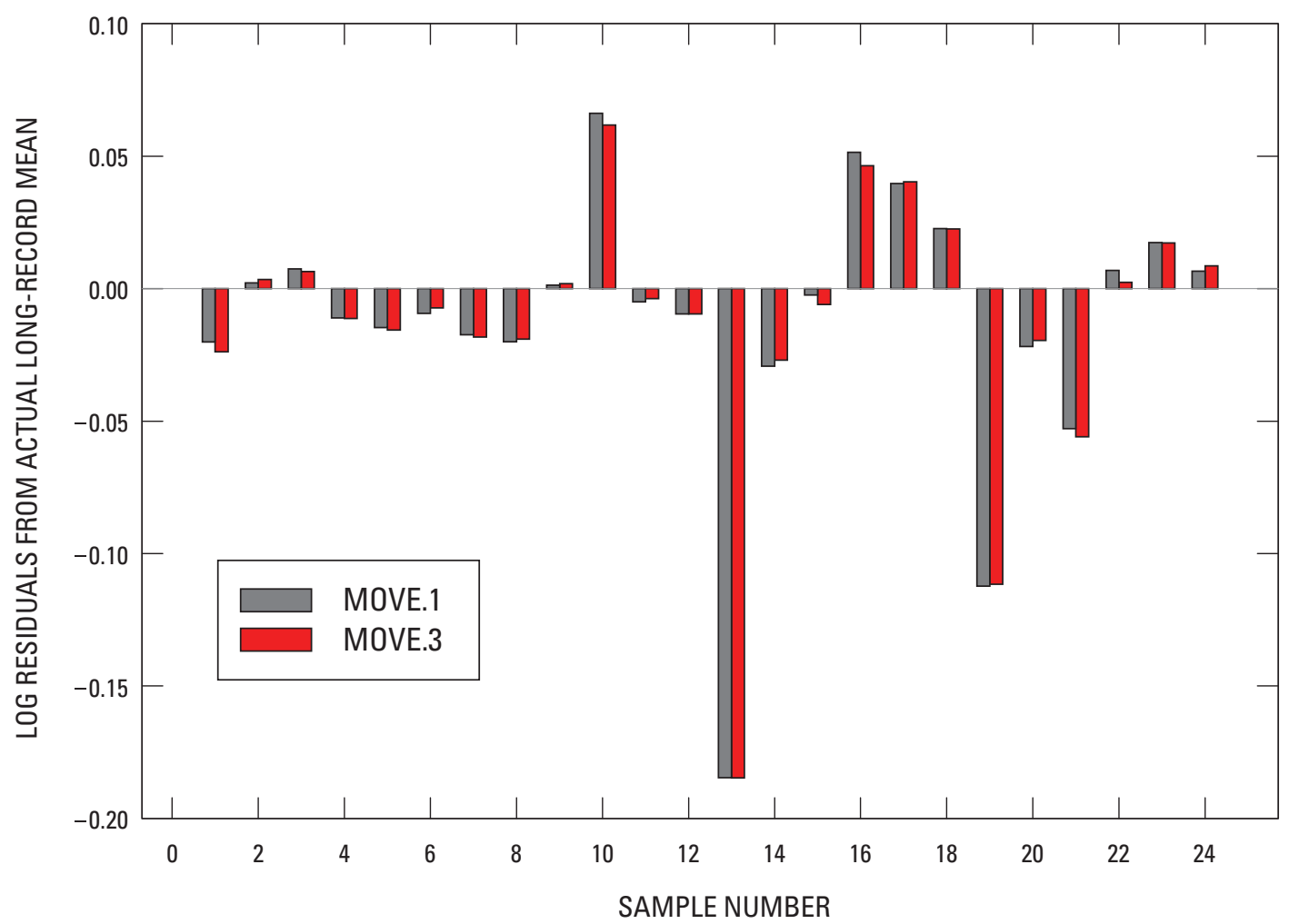

Figure A2. Sample by sample comparison of MOVE. 1 and MOVE.3 to estimate the mean of the logs of annual-peak discharges from the logs of annual-maximum-daily discharge based on data from four sites $(24$ samples) in California.

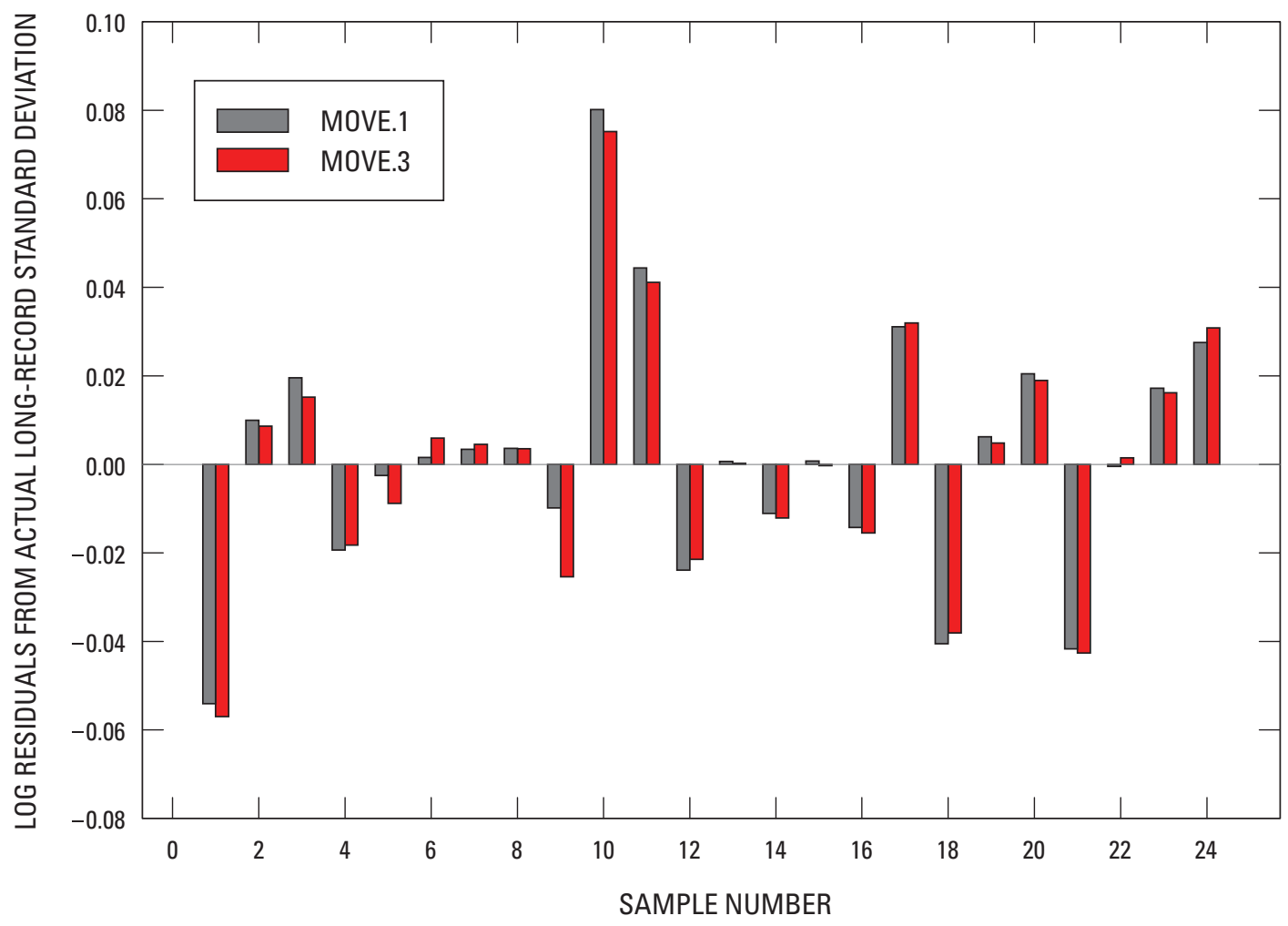

Figure A3. Sample by sample comparison of MOVE. 1 and MOVE. 3 to estimate the standard deviation of the logs of annual-peak discharges from the logs of annualmaximum-daily discharge based on data from four sites (24 samples) in California. 
The site-specific MOVE.1 equations developed for the ten sites were converted to power relations based on discharge rather than the logarithms of discharge to generate unregulated annual-peak discharge estimates for each year after dam construction for which the ACOE had previously estimated unregulated, annual-maximum-daily discharge. The power equations are of the form

$$
y_{i}=A x_{i}^{b}
$$

where

$y_{i}$ are the calculated annual-peak discharges,

$x_{i}$ are the unregulated, annual- maximum-dailydischarges, and

$\mathrm{b}$ is the power equation exponent already defined in equation (A4).

The power equation coefficient can be expressed using terms already defined in the basic MOVE.1 equations (A1 through A4) as

$$
A=10^{\left(a-b \bar{X}_{1}\right)} .
$$

Table A2 shows the ten sites for which a MOVE.1 equation was developed and pertinent data for the MOVE.1 relation, including record lengths $n_{1}$ and $n_{2}$, the power equation coefficient and exponent, and the Pearson correlation coefficient. The correlations between the concurrent unregulated, annual-maximum-daily-discharges and the annual-peak discharges exceeded 0.90 for every site. Thus, the MOVE analysis provided a reliable extension of the annual peak-discharge records. All but one of the exponents were greater than one, indicating that the annual-peak discharge values varied more than the annual-maximum-daily discharge values.

For 6 of the 16 sites that had no earlier periods of concurrent unregulated, annual-peak-discharge and annualmaximum-daily discharge record, a MOVE.1 equation developed for a nearby and similar site that had long concurrent records for the two series was adjusted for scale and used to generate unregulated, annual-peak discharges for the entire period for which the ACOE had developed unregulated, annual maximum-daily-discharge estimates. The general MOVE equation (eq. A1) for the nearby site is written $Y_{i}=a+b\left(X_{i}-\bar{X}_{1}\right)$, where $Y$ and $X$ refer to the concurrent records of logarithms of annual-peak discharge and annualmaximum-daily discharge data for each nearby site. Because the six "estimation sites" do not have concurrent records of annual-peak and daily-maximum discharge of length $n_{1}$ and separate extension periods, there is no MOVE. 1 versus MOVE. 3 problem, and the method can be described as a general MOVE procedure.

Table A2. Ten sites for which MOVE.1 was used to extend unregulated peak flow record in the Sacramento-San Joaquin River Basin, California.

[ $n_{1}$ is the length of concurrent daily-maximum and peak-flow record, in years. $n_{2}$ is the length of the non-concurrent maximum-daily-discharge record, in years.

\begin{tabular}{|c|c|c|c|c|c|c|}
\hline \multirow{2}{*}{$\begin{array}{c}\text { Station } \\
\text { number }\end{array}$} & \multirow{2}{*}{ Names of stations } & \multicolumn{2}{|c|}{$\begin{array}{l}\text { Period of unregulated, annual-maximum } \\
\text { flow record }\end{array}$} & \multicolumn{2}{|c|}{ Power equation } & \multirow{2}{*}{$\begin{array}{c}\text { Pearson } \\
\text { correlation } \\
\text { coefficient }(r)\end{array}$} \\
\hline & & Daily & Peak $^{2}$ & Coefficient & Exponent & \\
\hline 11222099 & Kings River at Piedra & 1896-1999 (104) & $\begin{array}{l}\text { 1900-02, 1904-07, } \\
\text { 1909-53 (52) }\end{array}$ & 0.179 & 1.215 & 0.91 \\
\hline 11258099 & Fresno River below Hidden Dam & 1942-99 (59) & $1942-75(34)$ & 0.961 & 1.075 & 0.98 \\
\hline 11270099 & Merced River at Exchequer & 1902-14,1916-99 (96) & $\begin{array}{l}1902-13,1916-25 \\
\quad(22)\end{array}$ & 0.737 & 1.059 & 0.97 \\
\hline 11323599 & $\begin{array}{l}\text { Mokelumne River below Camanche } \\
\text { Dam }\end{array}$ & 1905-97 (93) & 1905-28 (24) & 1.115 & 1.012 & 0.97 \\
\hline 11335099 & Cosumnes River at Michigan Bar & 1908-97 (90) & $1908-54(47)$ & 1.099 & 1.031 & 0.98 \\
\hline 11413599 & N Yuba River below Bullards Bar Dam & 1941-66,1970-97 (54) & 1941-66 (26) & 0.486 & 1.116 & 0.98 \\
\hline 11446599 & American River at Fair Oaks & 1905-98 (94) & $\begin{array}{c}\text { 1905-09, 1911-17, } \\
1919-54(48)\end{array}$ & 0.835 & 1.045 & 0.99 \\
\hline
\end{tabular}
$\mathrm{N}$, north]

\footnotetext{
${ }^{1}$ The station number is the U.S. Geological Survey station number with the last two digits replaced by "99."

${ }^{2}$ Peaks recorded during years when no daily maxima were available are not included in $n_{1}$.
} 
Using a MOVE relation developed for a nearby site is based on the assumption that flows at the estimation site are $\mathrm{k}$ times larger or smaller than the corresponding flows at the nearby site. Thus, for each of the six estimation sites, the logarithms of annual-peak discharge are $U_{i}=Y_{i}+\log (k)$ and the logarithms of annual-maximum-daily discharge are $\mathrm{V}_{\mathrm{i}}=\mathrm{X}_{\mathrm{i}}+\log (\mathrm{k})$. Substituting these relations in the basic MOVE equation (eq. A1) yields

$$
U_{i}-\log (k)=a+b\left[V_{i}-\log (k)-\bar{X}\right\rceil,
$$

which can be rewritten to show the relation between the values that have been measured at the estimation site $\left(V_{i}\right)$ and the values that are to be generated $\left(\mathrm{U}_{\mathrm{i}}\right)$ :

$$
U_{i}=[(a-b \bar{X})+(1-b) \log (k)]+b V_{i} .
$$

Finally, $\log (k)$ is estimated as the mean logarithm of annualmaximum-daily discharge at the estimation site $(\bar{V})$ minus the mean logarithm of annual-maximum-daily discharge at the nearby site $(\bar{X})$. With that estimator for $\log (k)$, the MOVE equation for annual-peak discharge at the estimation site can be expressed simply in terms of the annual-maximum-daily discharge at the estimation site and the MOVE constant and coefficient developed for concurrent discharges at the nearby site so that

$$
U_{i}=\left[(a+\bar{V}-\bar{X})+b\left(V_{i}-\bar{V}\right)\right]
$$

Thus, the term $\log (k)$, which equals $\bar{V}-\bar{X}$ becomes a scaling factor that is added to the MOVE constant for the nearby site to correct for differences in discharge magnitudes at the two sites.

To help determine which nearby site was most suitable for each of the six estimation sites, a correlation analysis of the logs of concurrent annual-maximum-daily discharges at the estimation site and at several nearby sites was used. In general, the nearby site for which the Pearson correlation coefficient was the greatest was selected; however, some sites that had a smaller Pearson correlation coefficient but a longer period of concurrent annual-maximum-daily discharges or that had a MOVE relation based on a longer period of concurrent annualpeak discharge and annual-maximum-daily discharge were selected. Table A3 shows the selected nearby site for each of the six estimation sites, the Pearson correlation coefficient, and the period of concurrent annual-maximum-daily discharges. The nearby sites had reasonably similar hydrologic responses to the estimation sites based on the correlation coefficients and the periods of concurrent discharge. All values of the Pearson correlation coefficient were greater than 0.75 and several exceeded 0.90 (table A3).

The final MOVE equations were converted to a power form and used to calculate annual-peak discharges at each of the six estimation sites from the record of annualmaximum-daily discharge. Table A3 also includes the scaling (adjustment) factor applied to the MOVE constant for the nearby site $[\log (k)=\bar{V}-\bar{X}]$ and values of the adjusted power equation coefficient (A) and exponent (b) for each MOVE equation. The adjusted power equation coefficient (A) was calculated after adding the needed scaling factor.

Table A3. Six sites that had no unregulated peak flow record, selected nearby sites, Pearson correlation coefficients, and concurrent records for paired sites, scaling factors, and power equation coefficients and exponents for the Sacramento-San Joaquin River Basin,

\begin{tabular}{|c|c|c|c|c|c|c|c|}
\hline \multirow[b]{2}{*}{$\begin{array}{c}\text { Station } \\
\text { numbers }\end{array}$} & \multirow{2}{*}{$\begin{array}{c}\text { Names of stations } \\
\text { that had no } \\
\text { unregulated } \\
\text { peak-flow } \\
\text { record }\end{array}$} & \multirow{2}{*}{$\begin{array}{l}\text { Names and USGS } \\
\text { numbers for } \\
\text { correlation stations } \\
\text { selected nearby }\end{array}$} & \multirow{2}{*}{$\begin{array}{l}\text { Pearson } \\
\text { correlation } \\
\text { coefficient } \\
(r)\end{array}$} & \multirow[b]{2}{*}{$\begin{array}{l}\text { Period of } \\
\text { concurrent } \\
\text { record }\end{array}$} & \multirow[b]{2}{*}{$\begin{array}{l}\text { Scaling } \\
\text { factors } \\
{[\log (k)]}\end{array}$} & \multicolumn{2}{|c|}{ Power equation } \\
\hline & & & & & & $\begin{array}{l}\text { Adjusted } \\
\text { coefficient } \\
\text { (A) }\end{array}$ & $\begin{array}{l}\text { Exponent } \\
\text { (b) }\end{array}$ \\
\hline 11251099 & San Joaquin River & Kings River (11222099) & 0.92 & 1911-99 & 0.0097 & 0.179 & 1.215 \\
\hline 11299599 & Stanislaus River & $\begin{array}{l}\text { Mokelumne River } \\
\quad \text { (11323599) }\end{array}$ & 0.91 & 1932-97 & 0.1496 & 1.003 & 1.011 \\
\hline 11308999 & Calaveras River & Cosumnes River (11335099) & 0.86 & 1964-97 & -0.1281 & 1.109 & 1.031 \\
\hline 11344099 & Littlejohns Creek & Cosumnes River (11335099) & 0.76 & 1951-97 & -0.5834 & 1.145 & 1.031 \\
\hline 11388099 & Stony Creek & Fresno River (11258099) & 0.88 & 1982-98 & 0.9484 & 0.817 & 1.075 \\
\hline
\end{tabular}
California.

[USGS, U.S. Geological Survey]

${ }^{1}$ Station number is the USGS station number with the last two digits replaced by "99." 
All exponents are greater than one, indicating that the annual-peak discharges have more variability than the annualmaximum-daily discharges.

The MOVE relations for each of the ten sites for which concurrent periods of recorded unregulated annual-peak discharges and annual-maximum-daily discharges were available are shown in figures A4 through $\mathrm{A} 13$. Correlations between annual-peak discharge and annual-maximum-daily discharge were compared with correlations between annualpeak discharge and annual-maximum 3-day discharge for each of the ten sites to test whether annual-maximum 3-day discharge might predict annual-peak discharge better than annual-maximum-daily discharge. For all ten sites, the correlations between annual-peak discharge and annualmaximum-daily discharge were larger than those between annual-peak discharge and annual-maximum 3-day discharge. On the basis of the tests at the ten sites having concurrent records of recorded unregulated annual-peak discharges and annual-maximum-daily discharges, annual-maximum-daily discharge was selected as the best predictor for annual-peak discharge for all 16 key dam sites.

Unregulated, annual-peak discharges for the 16 key dam sites are shown in table A4. These data are displayed in a form similar to that used by the version of the EMA program used for flood-frequency analyses in California. Most of the tabulated annual-peak discharges were calculated from the MOVE. 1 relations described above, although periods of recorded, unregulated annual-peak discharges at the ten sites are also included and noted in the table.

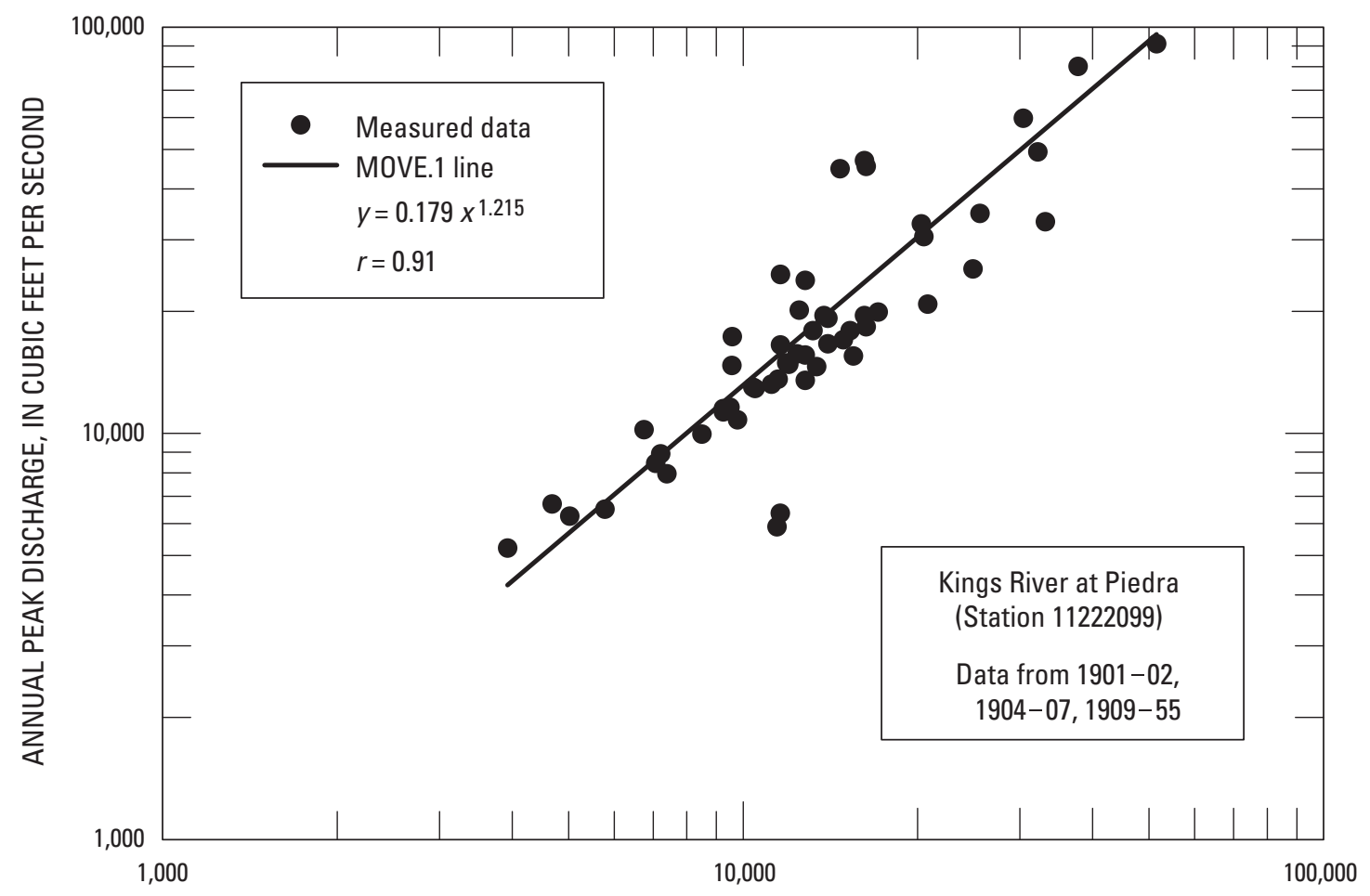

ANNUAL 1-DAY MAXIMUM DISCHARGE, IN CUBIC FEET PER SECOND

Figure A4. MOVE.1 line relating annual-peak discharge to annual-maximum-daily discharge for Kings River at Piedra, California, (station 11222099) based on data from 1901-02, 1904-07, and 1909-55. $r$, Pearson correlation coefficient. 


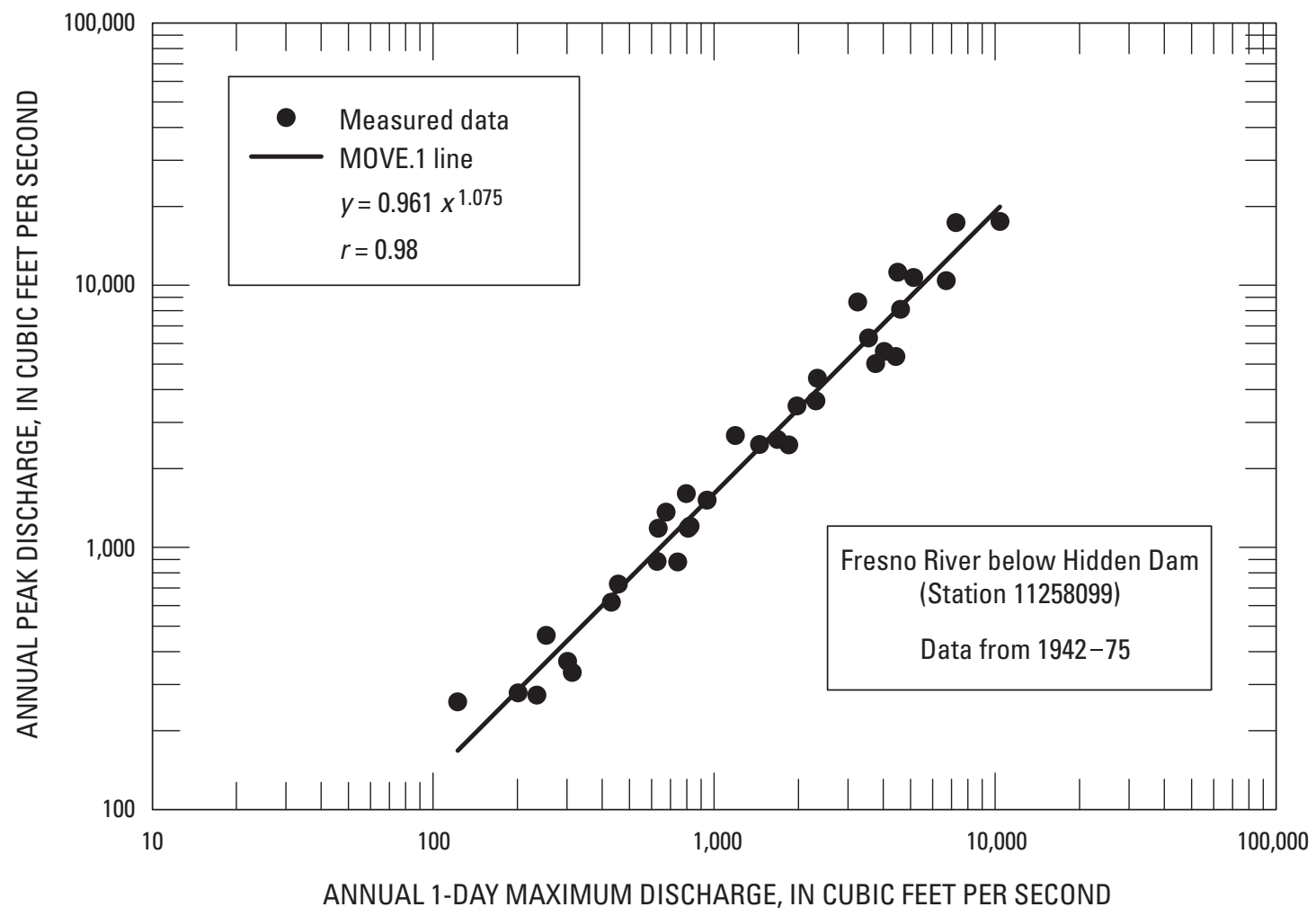

Figure A5. MOVE.1 line relating annual-peak discharge to annual-maximum-daily discharge for Fresno River below Hidden Dam, California, (station 11258099) based on data from 1942-75. $r$, Pearson correlation coefficient.

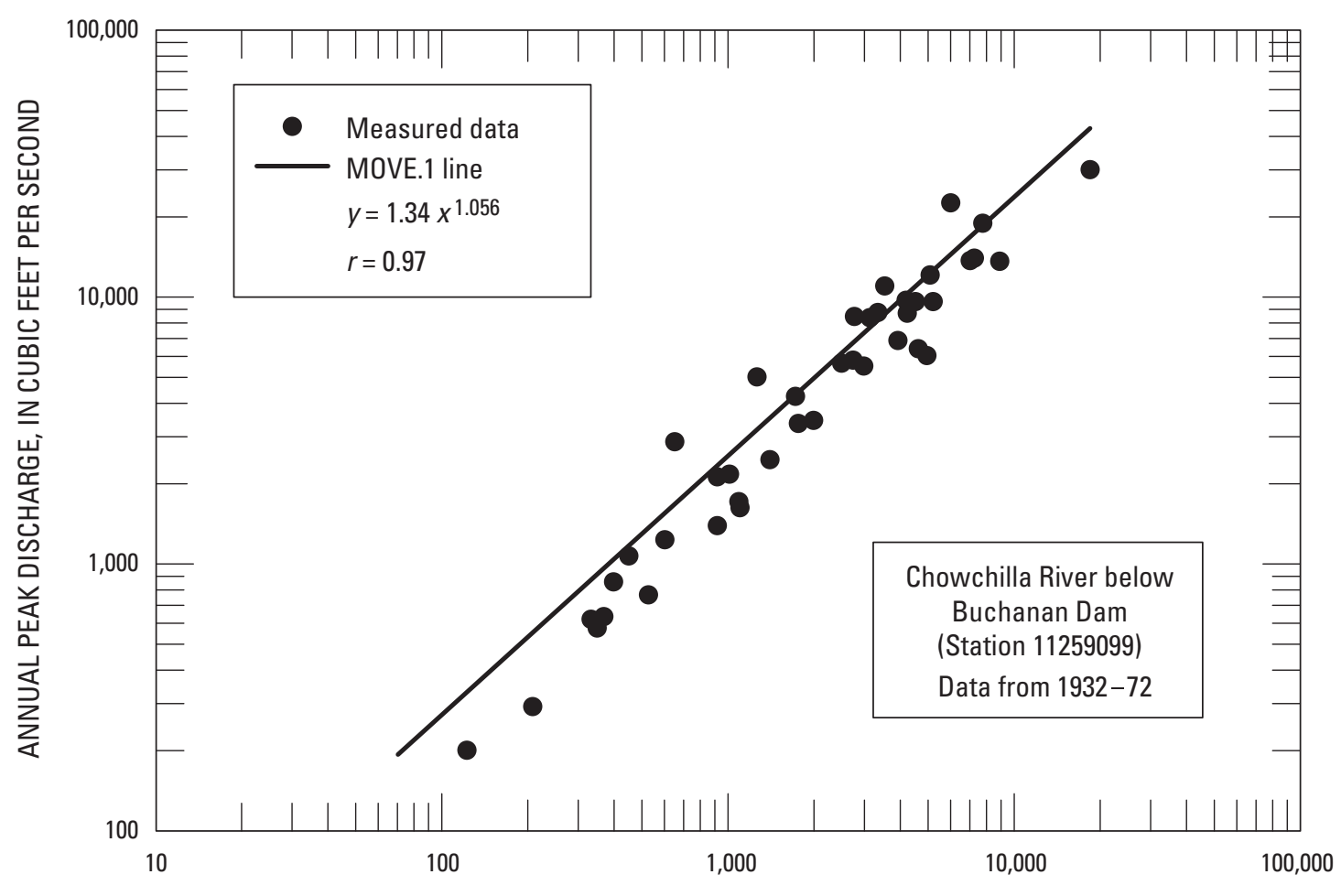

ANNUAL 1-DAY MAXIMUM DISCHARGE, IN CUBIC FEET PER SECOND

Figure A6. MOVE.1 line relating annual-peak discharge to annual annual-maximum-daily discharge for Chowchilla River below Buchanan Dam, California (station 11259099) based on data from 1932-72. $r$, Pearson correlation coefficient. 


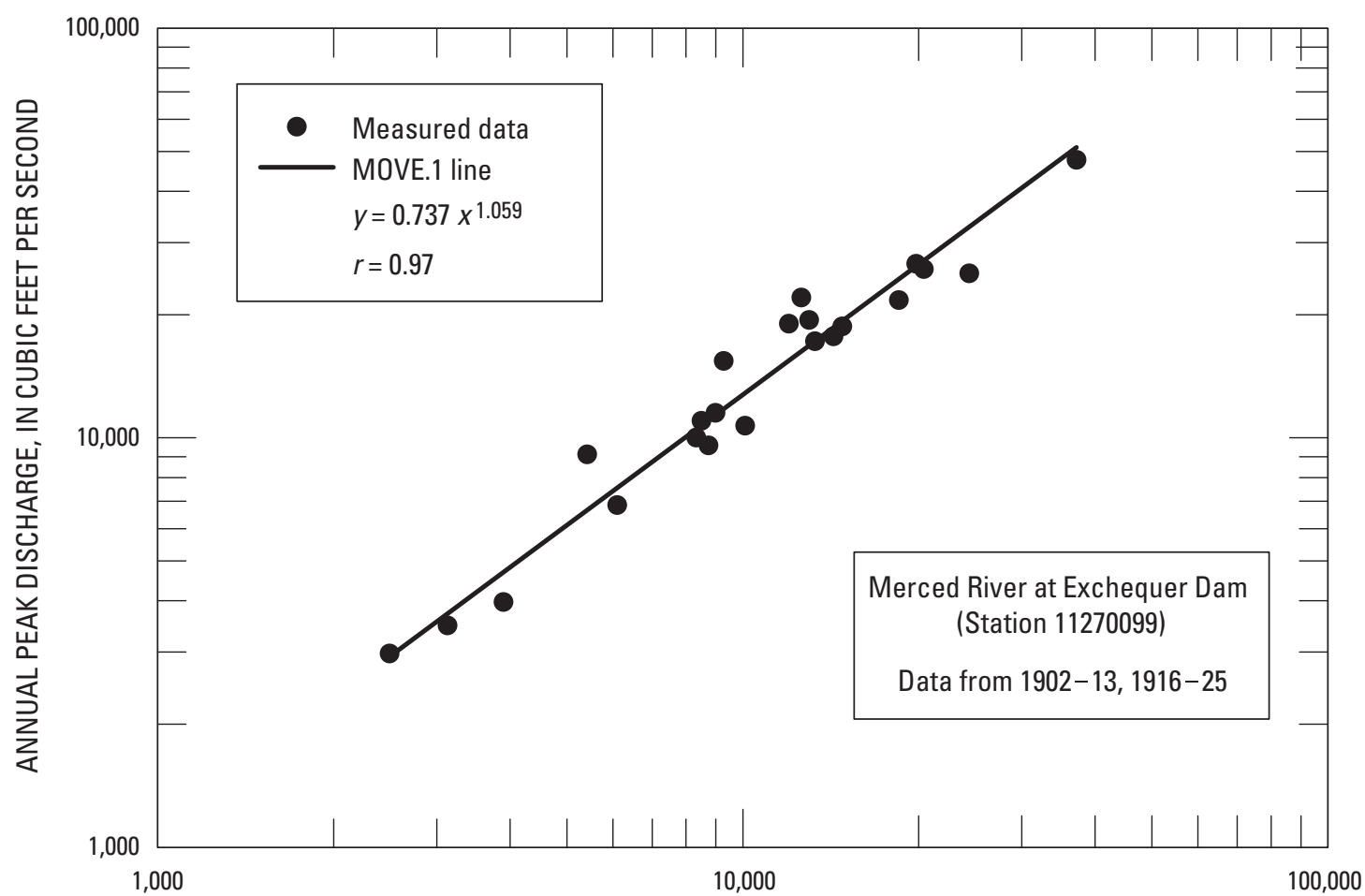

ANNUAL 1-DAY MAXIMUM DISCHARGE, IN CUBIC FEET PER SECOND

Figure A7. MOVE.1 line relating annual-peak discharge to annual-maximum-daily discharge for Merced River at Exchequer Dam, California, (station 11270099) based on data from 1902-13, 1916-25. r, Pearson correlation coefficient.

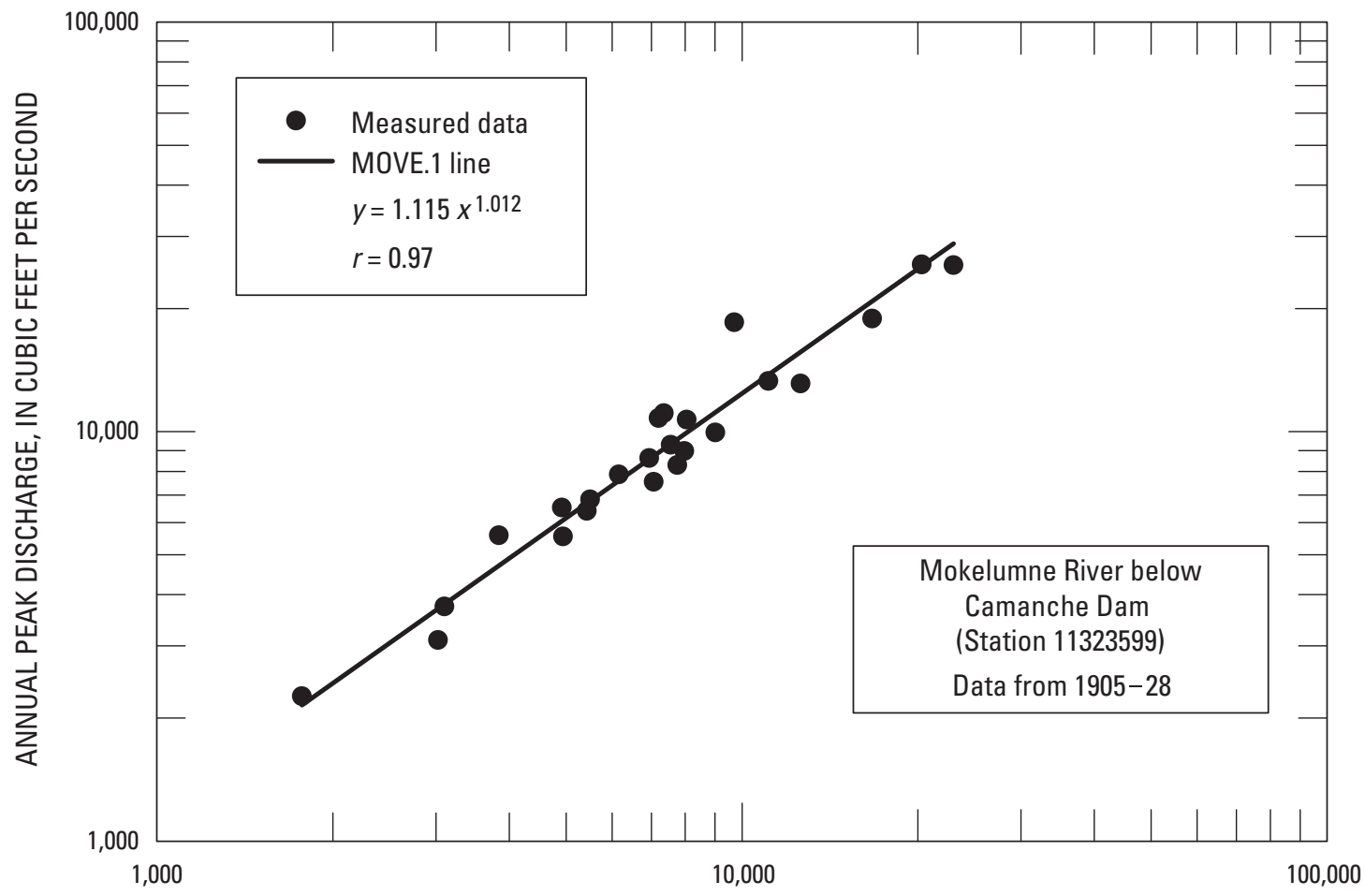

ANNUAL 1-DAY MAXIMUM DISCHARGE, IN CUBIC FEET PER SECOND

Figure A8. MOVE. 1 line relating annual-peak discharge to annual-maximum-daily discharge for Mokelumne River below Camanche Dam, California, (station 11323599) based on data from 1905-28. r, Pearson correlation coefficient. 


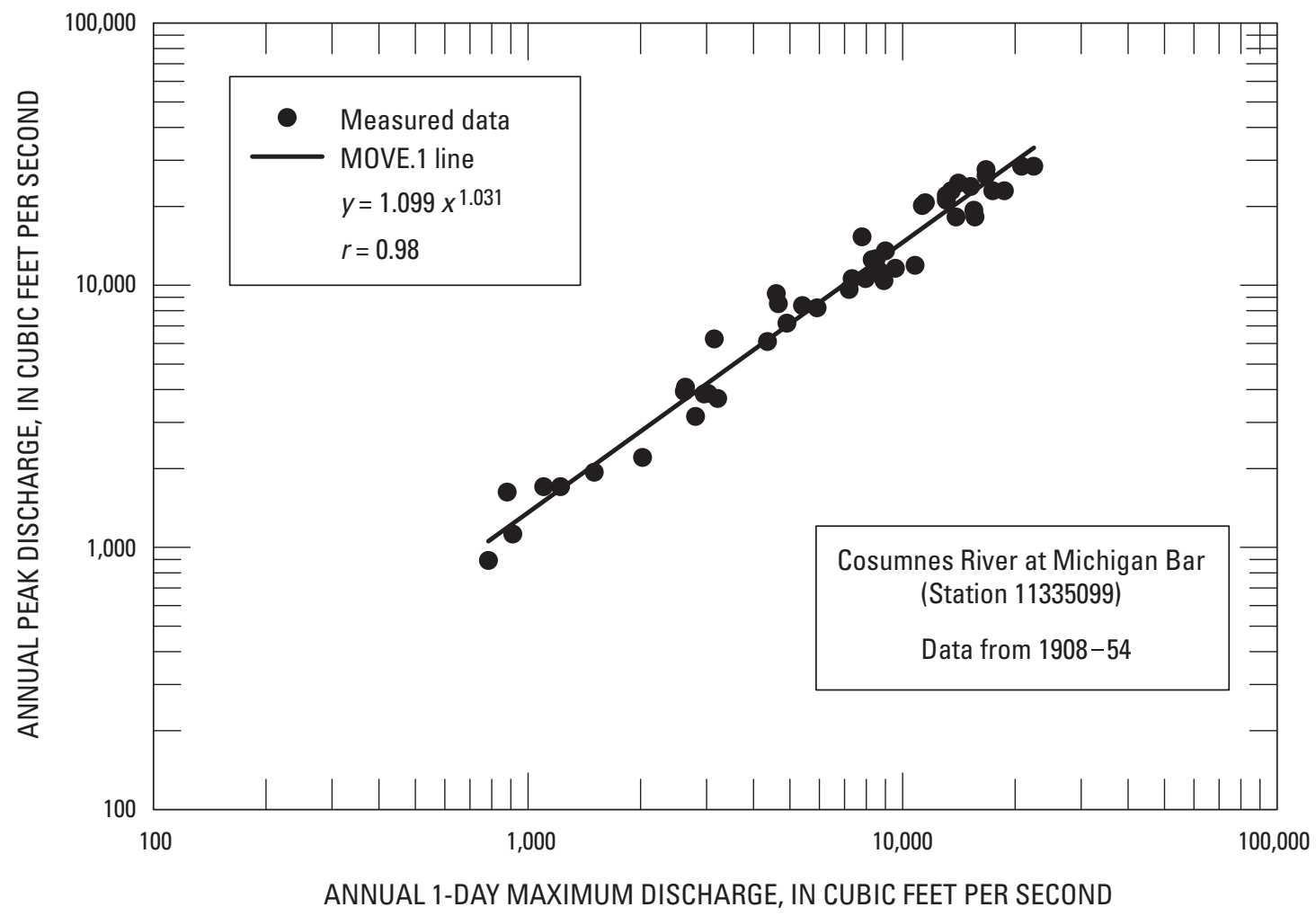

Figure A9. MOVE.1 line relating annual-peak discharge to annual-maximum-daily discharge for Cosumnes River at Michigan Bar, California, (station 11335099) based on data from 1908-54. $r$, Pearson correlation coefficient.

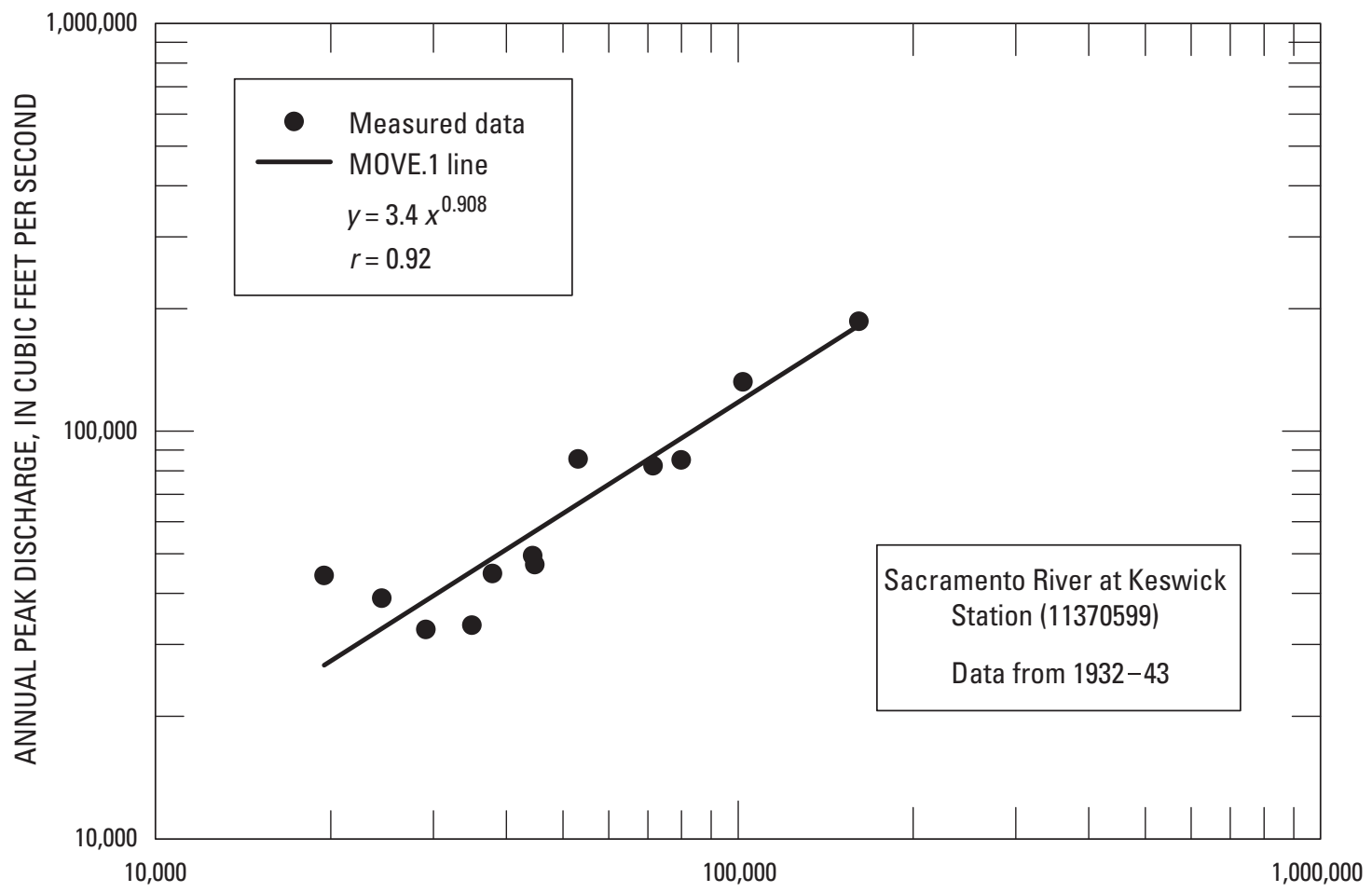

ANNUAL 1-DAY MAXIMUM DISCHARGE, IN CUBIC FEET PER SECOND

Figure A10. MOVE.1 line relating annual-peak discharge to annual-maximum-daily discharge for Sacramento River at Keswick, California (station 11370599) based on data from 1932-43. $r$, Pearson correlation coefficient. 


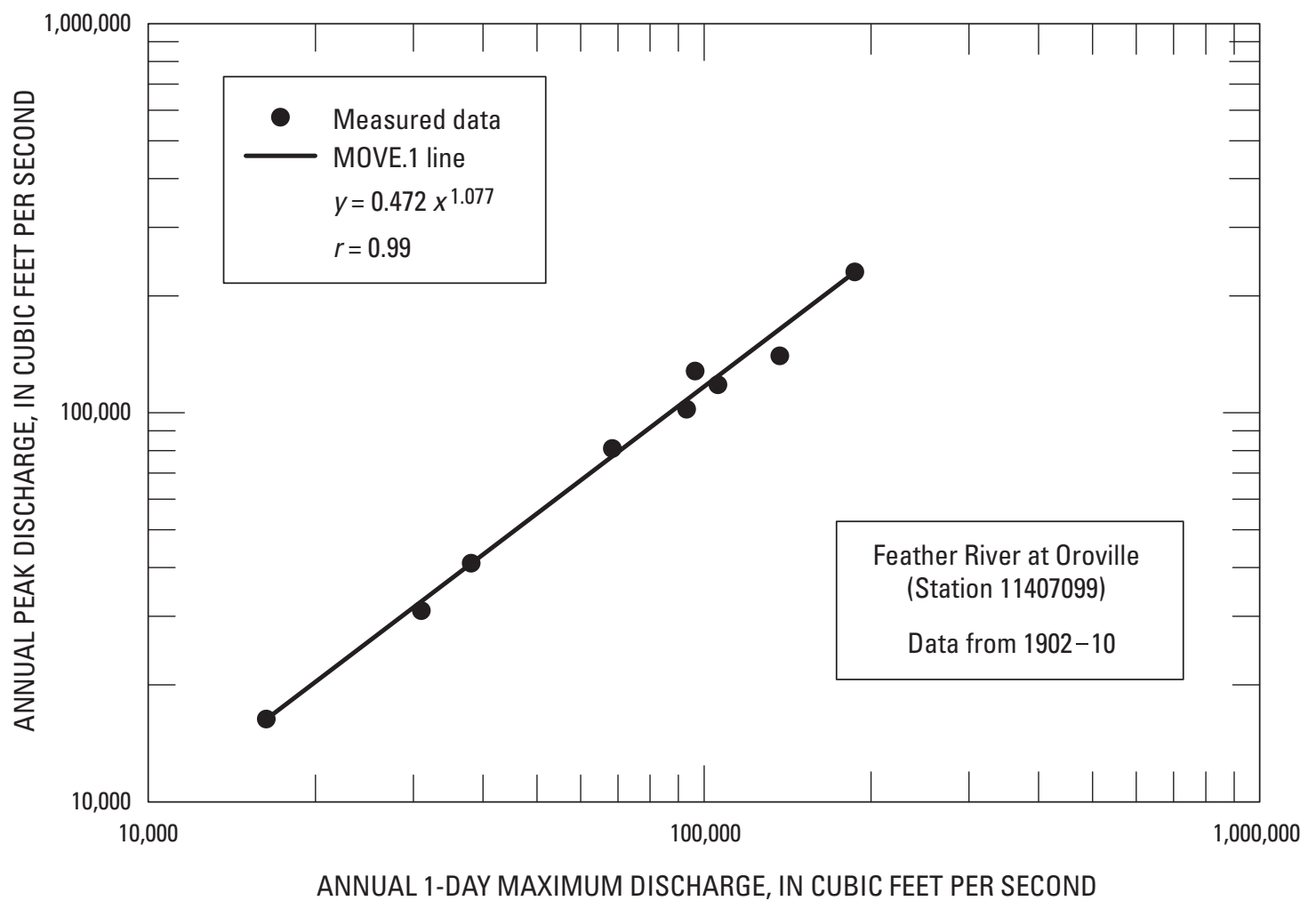

Figure A11. MOVE.1 line relating annual-peak discharge to annual-maximum-daily discharge for Feather River at Oroville, California, (station 11407099) based on data from 1902-10. r, Pearson correlation coefficient.

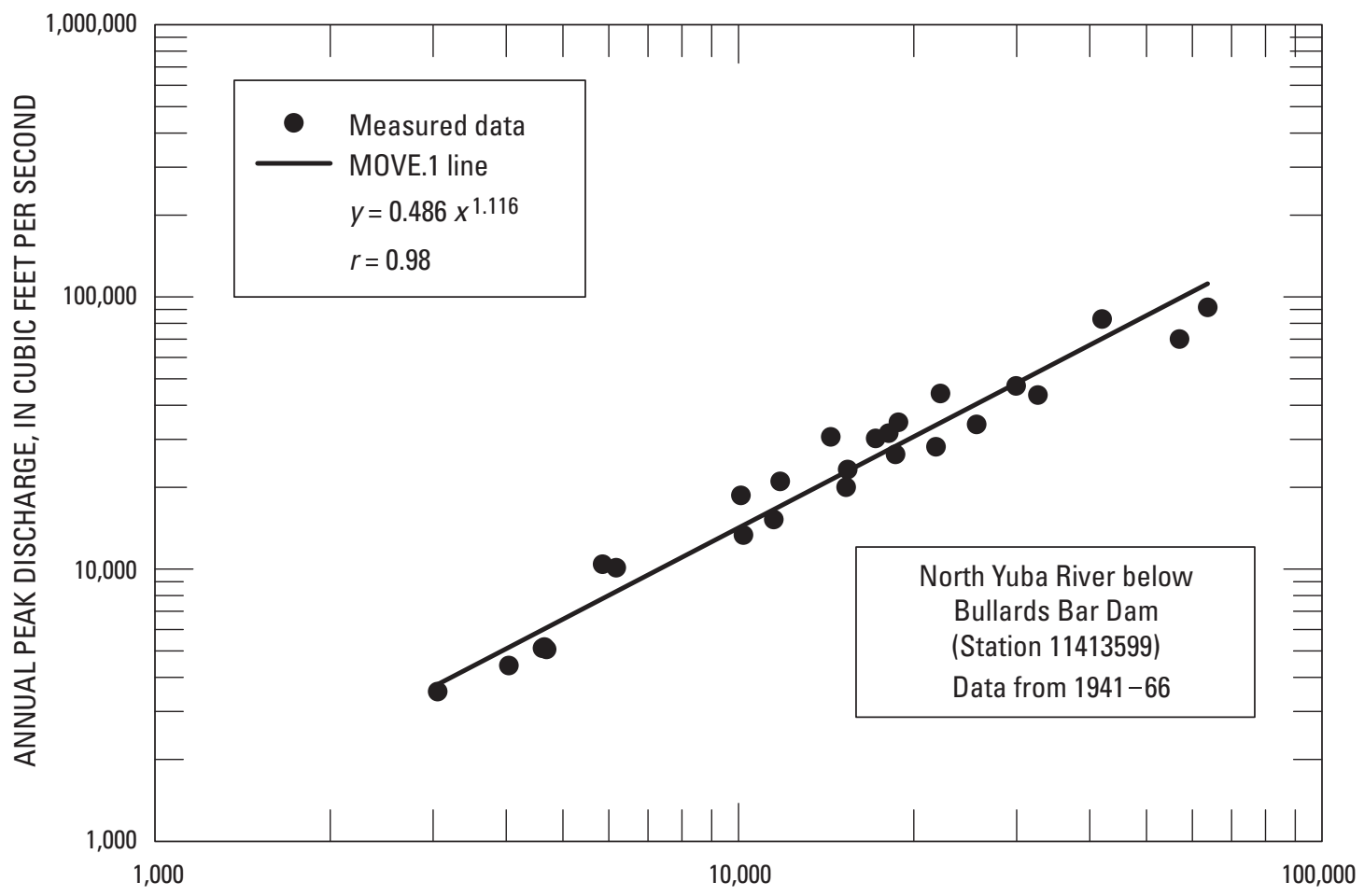

ANNUAL 1-DAY MAXIMUM DISCHARGE, IN CUBIC FEET PER SECOND

Figure A12. MOVE.1 line relating annual-peak discharge to annual-maximum-daily discharge for North Yuba River below Bullards Bar Dam, California, (station 11413599) based on data from 1941-66. $r$, Pearson correlation coefficient. 


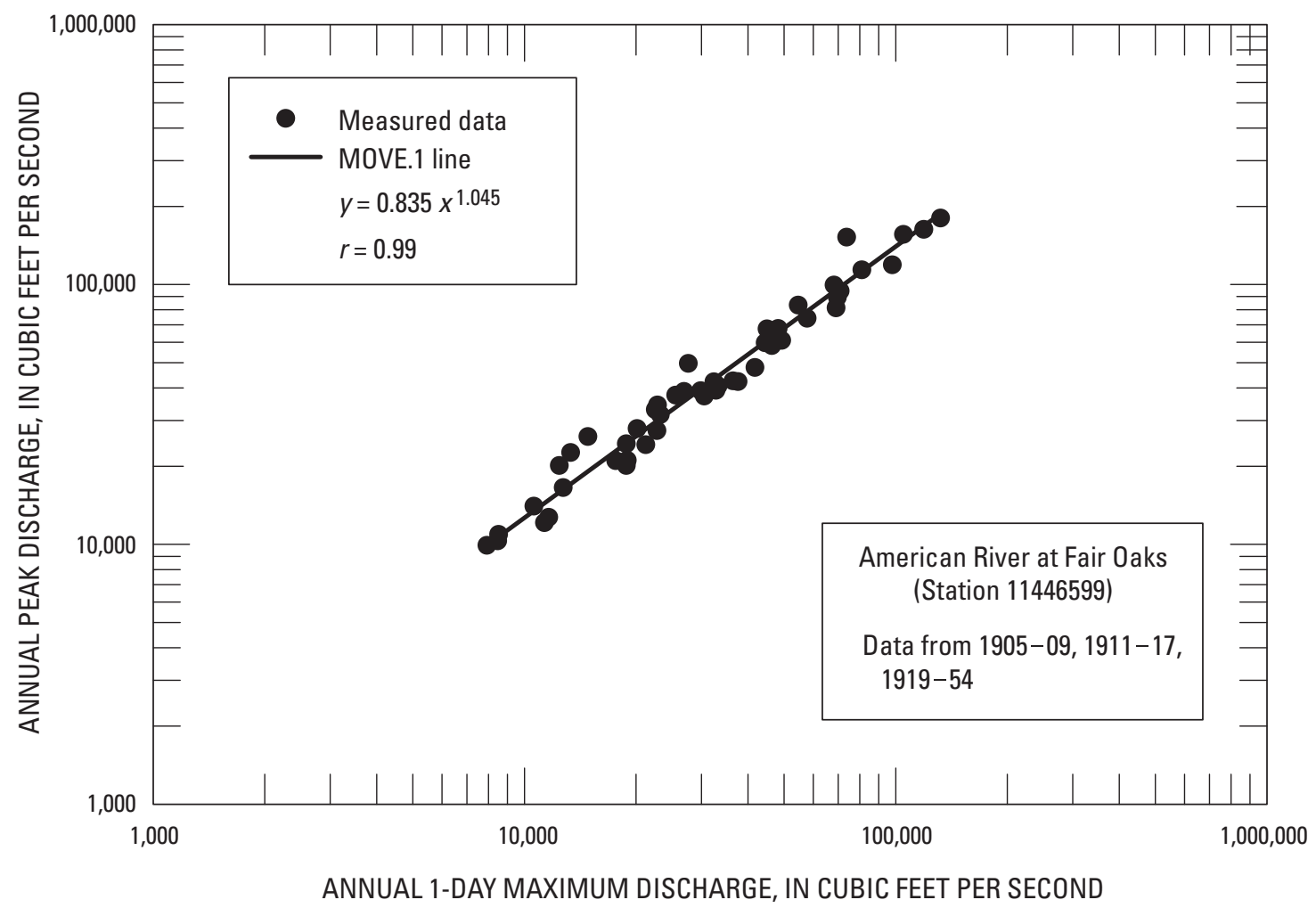

Figure A13. MOVE.1 line relating annual-peak discharge to annual-maximum-daily discharge for American River at Fair Oaks, California, (station 11446599) based on data from 1905-09, 1911-17, 1919-54. r, Pearson correlation coefficient. 
Table A4. Estimated, unregulated annual peak discharge for key dam sites in the Sacramento-San Joaquin River Basin, California.

[For some stations, missing discharges are represented by interval discharge thresholds. These sites have a row of data after the STATION row with THRESHOLD indicated. The next two numbers in the THRESHOLD row show the first and last year of missing record. The next number represents a large discharge threshold that presumably was not reached during the missing years. The INF following the threshold discharge simply indicates the largest possible discharge during the missing years (infinitely large). The first column after the STATION and THRESHOLD rows indicates whether discharge is a single-valued discharge (Q) or an interval discharge (QINT). Second column is the water year for each discharge. For each single-valued discharge, the third column is the discharge in cubic feet per second, and for each interval discharge, the third and fourth columns represent the range in discharge in cubic feet per second. For each single-valued discharge, a value of 1 in the last column indicates that the discharge is a recorded, unregulated, discharge. A value of 2 in the last column indicates that the discharge was a recorded, regulated discharge]

Station - 11222099 Kings River at Piedra, California (simulated unregulated peaks)

\begin{tabular}{|c|c|c|c|}
\hline Q & 1896 & 12,000 & \\
\hline $\mathrm{Q}$ & 1897 & 26,100 & \\
\hline $\mathrm{Q}$ & 1898 & 10,100 & \\
\hline Q & 1899 & 37,600 & \\
\hline Q & 1900 & 14,600 & 1 \\
\hline $\mathrm{Q}$ & 1901 & 33,200 & 1 \\
\hline Q & 1902 & 20,800 & 1 \\
\hline Q & 1903 & 21,200 & \\
\hline $\mathrm{Q}$ & 1904 & 19,500 & 1 \\
\hline Q & 1905 & 10,800 & 1 \\
\hline Q & 1906 & 25,400 & 1 \\
\hline Q & 1907 & 19,500 & 1 \\
\hline Q & 1908 & 7,630 & \\
\hline Q & 1909 & 32,800 & 1 \\
\hline Q & 1910 & 44,800 & 1 \\
\hline $\mathrm{Q}$ & 1911 & 30,500 & 1 \\
\hline Q & 1912 & 15,700 & 1 \\
\hline Q & 1913 & 8,900 & 1 \\
\hline Q & 1914 & 59,700 & 1 \\
\hline Q & 1915 & 18,300 & 1 \\
\hline Q & 1916 & 45,400 & 1 \\
\hline Q & 1917 & 17,900 & 1 \\
\hline Q & 1918 & 13,500 & 1 \\
\hline Q & 1919 & 13,200 & 1 \\
\hline $\mathrm{Q}$ & 1920 & 17,000 & 1 \\
\hline Q & 1921 & 15,600 & 1 \\
\hline Q & 1922 & 19900 & 1 \\
\hline Q & 1923 & 13,600 & 1 \\
\hline Q & 1924 & 5,210 & 1 \\
\hline Q & 1925 & 11,300 & 1 \\
\hline Q & 1926 & 11,600 & 1 \\
\hline Q & 1927 & 1,9200 & 1 \\
\hline Q & 1928 & 10,200 & 1 \\
\hline $\mathrm{Q}$ & 1929 & 14,700 & 1 \\
\hline Q & 1930 & 8,430 & 1 \\
\hline Q & 1931 & 6,250 & 1 \\
\hline Q & 1932 & 23,800 & 1 \\
\hline Q & 1933 & 14,900 & 1 \\
\hline Q & 1934 & 6,690 & 1 \\
\hline
\end{tabular}


Table A4. Estimated, unregulated annual peak discharge for key dam sites in the SacramentoSan Joaquin River Basin, California.-Continued

[For some stations, missing discharges are represented by interval discharge thresholds. These sites have a row of data after the STATION row with THRESHOLD indicated. The next two numbers in the THRESHOLD row show the first and last year of missing record. The next number represents a large discharge threshold that presumably was not reached during the missing years. The INF following the threshold discharge simply indicates the largest possible discharge during the missing years (infinitely large). The first column after the STATION and THRESHOLD rows indicates whether discharge is a single-valued discharge (Q) or an interval discharge (QINT). Second column is the water year for each discharge. For each single-valued discharge, the third column is the discharge in cubic feet per second, and for each interval discharge, the third and fourth columns represent the range in discharge in cubic feet per second. For each single-valued discharge, a value of 1 in the last column indicates that the discharge is a recorded, unregulated, discharge. A value of 2 in the last column indicates that the discharge was a recorded, regulated discharge]

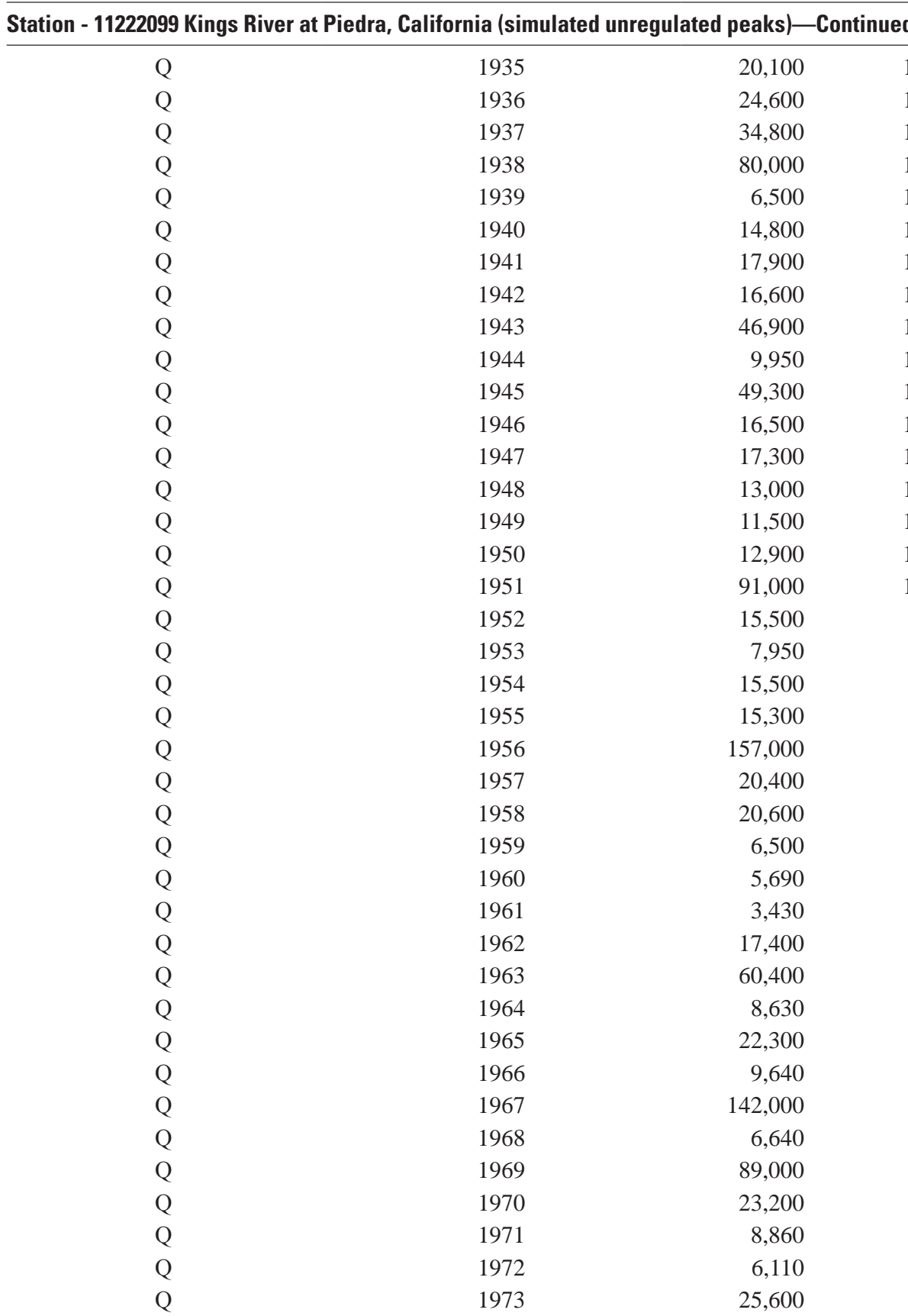


Table A4. Estimated, unregulated annual peak discharge for key dam sites in the SacramentoSan Joaquin River Basin, California.-Continued

[For some stations, missing discharges are represented by interval discharge thresholds. These sites have a row of data after the STATION row with THRESHOLD indicated. The next two numbers in the THRESHOLD row show the first and last year of missing record. The next number represents a large discharge threshold that presumably was not reached during the missing years. The INF following the threshold discharge simply indicates the largest possible discharge during the missing years (infinitely large). The first column after the STATION and THRESHOLD rows indicates whether discharge is a single-valued discharge (Q) or an interval discharge (QINT). Second column is the water year for each discharge. For each single-valued discharge, the third column is the discharge in cubic feet per second, and for each interval discharge, the third and fourth columns represent the range in discharge in cubic feet per second. For each single-valued discharge, a value of 1 in the last column indicates that the discharge is a recorded, unregulated, discharge. A value of 2 in the last column indicates that the discharge was a recorded, regulated discharge]

Station - 11222099 Kings River at Piedra, California (simulated unregulated peaks) —Continued

\begin{tabular}{lrr}
\hline Q & 1974 & 20,400 \\
Q & 1975 & 22,600 \\
Q & 1976 & 780 \\
Q & 1977 & 4,820 \\
Q & 1978 & 31,800 \\
Q & 1979 & 20,500 \\
Q & 1980 & 62,100 \\
Q & 1981 & 11,700 \\
Q & 1982 & 96,100 \\
Q & 1983 & 46,900 \\
Q & 1984 & 18,800 \\
Q & 1985 & 9,080 \\
Q & 1986 & 45,400 \\
Q & 1987 & 6,990 \\
Q & 1988 & 9,570 \\
Q & 1989 & 7,010 \\
Q & 1990 & 5,140 \\
Q & 1991 & 18,800 \\
Q & 1992 & 6,730 \\
Q & 1993 & 23,800 \\
Q & 1994 & 9,630 \\
Q & 1995 & 49,200 \\
Q & 1996 & 99,200 \\
Q & 1997 & 11,300 \\
Q & 1998 & \\
Q & 1999 & \\
\hline & & \\
\hline
\end{tabular}

Station - 11251099 San Joaquin River below Friant, California (simulated unregulated peaks)

\begin{tabular}{lrr}
\hline Q & 1911 & 1,800 \\
Q & 1912 & 21,900 \\
Q & 1913 & 8,170 \\
Q & 1914 & 43,900 \\
Q & 1915 & 21,500 \\
Q & 1916 & 18,700 \\
Q & 1917 & 19,100 \\
Q & 1918 & 15,500 \\
Q & 1919 & 14,800 \\
Q & 1920 & 17,500 \\
Q & 1921 & 16,800
\end{tabular}


Table A4. Estimated, unregulated annual peak discharge for key dam sites in the SacramentoSan Joaquin River Basin, California.-Continued

[For some stations, missing discharges are represented by interval discharge thresholds. These sites have a row of data after the STATION row with THRESHOLD indicated. The next two numbers in the THRESHOLD row show the first and last year of missing record. The next number represents a large discharge threshold that presumably was not reached during the missing years. The INF following the threshold discharge simply indicates the largest possible discharge during the missing years (infinitely large). The first column after the STATION and THRESHOLD rows indicates whether discharge is a single-valued discharge (Q) or an interval discharge (QINT). Second column is the water year for each discharge. For each single-valued discharge, the third column is the discharge in cubic feet per second, and for each interval discharge, the third and fourth columns represent the range in discharge in cubic feet per second. For each single-valued discharge, a value of 1 in the last column indicates that the discharge is a recorded, unregulated, discharge. A value of 2 in the last column indicates that the discharge was a recorded, regulated discharge]

Station - 11251099 San Joaquin River below Friant, California (simulated unregulated peaks)_Continued

Q

Q

Q

Q

Q

Q

Q

Q

Q

Q

Q

Q

Q

Q

Q

Q

Q

Q

Q

Q

Q

Q

Q

Q

Q

Q

Q

Q

Q

Q

Q

Q

Q

Q

Q

Q

Q

Q
1922

1923

1924

1925

1926

1927

1928

1929

1930

1931

1932

1933

1934

1935

1936

1937

1938

1939

1940

1941

1942

1943

1944

1945

1946

1947

1948

1949

1950

1951

1952

1953

1954

1955

1956

1957

1958

1959

1960
26,700

15,500

4,500

12,800

13,100

19,000

14,600

10,800

7,780

4,700

20,500

15,000

3,720

18,800

14,000

27,500

70,600

6,020

14,800

23,100

20,500

24,700

10,200

57,800

14,400

10,900

13,900

12,700

14,000

74,500

26,600

10,500

14,100

15,400

149,000

24,300

25,500

9,730

7,810 
Table A4. Estimated, unregulated annual peak discharge for key dam sites in the SacramentoSan Joaquin River Basin, California.-Continued

[For some stations, missing discharges are represented by interval discharge thresholds. These sites have a row of data after the STATION row with THRESHOLD indicated. The next two numbers in the THRESHOLD row show the first and last year of missing record. The next number represents a large discharge threshold that presumably was not reached during the missing years. The INF following the threshold discharge simply indicates the largest possible discharge during the missing years (infinitely large). The first column after the STATION and THRESHOLD rows indicates whether discharge is a single-valued discharge (Q) or an interval discharge (QINT). Second column is the water year for each discharge. For each single-valued discharge, the third column is the discharge in cubic feet per second, and for each interval discharge, the third and fourth columns represent the range in discharge in cubic feet per second. For each single-valued discharge, a value of 1 in the last column indicates that the discharge is a recorded, unregulated, discharge. A value of 2 in the last column indicates that the discharge was a recorded, regulated discharge]

Station - 11251099 San Joaquin River below Friant, California (simulated unregulated peaks)— Continued

Q

Q

Q

Q

Q

Q

Q

Q

Q

Q

Q

Q

Q

Q

Q

Q

Q

Q

Q

Q

Q

Q

Q

Q

Q

Q

Q

Q

Q

Q

Q

Q

Q

Q

Q

Q

Q

Q

Q

$\begin{array}{rr}1961 & 4,050 \\ 1962 & 19,100 \\ 1963 & 71,600 \\ 1964 & 7,870 \\ 1965 & 40,300 \\ 1966 & 9,020 \\ 1967 & 74,600 \\ 1968 & 6,180 \\ 1969 & 47,700 \\ 1970 & 22,800 \\ 1971 & 10,700 \\ 1972 & 8,540 \\ 1973 & 24,700 \\ 1974 & 18,800 \\ 1975 & 24,500 \\ 1976 & 5,380 \\ 1977 & 5,840 \\ 1978 & 29,000 \\ 1979 & 19,900 \\ 1980 & 53,000 \\ 1981 & 10,300 \\ 1982 & 112000 \\ 1983 & 42,300 \\ 1984 & 26,700 \\ 1985 & 8,340 \\ 1986 & 56,100 \\ 1987 & 9,810 \\ 1988 & 6,480 \\ 1989 & 7,890 \\ 1990 & 5,400 \\ 1991 & 11,300 \\ 1992 & 6,940 \\ 1993 & 21,700 \\ 1994 & 8,300 \\ 1995 & 68,100 \\ 1996 & 53,400 \\ 1997 & 155,000 \\ 1998 & 30,300 \\ 1999 & 14,200 \\ & \end{array}$


Table A4. Estimated, unregulated annual peak discharge for key dam sites in the SacramentoSan Joaquin River Basin, California.-Continued

[For some stations, missing discharges are represented by interval discharge thresholds. These sites have a row of data after the STATION row with THRESHOLD indicated. The next two numbers in the THRESHOLD row show the first and last year of missing record. The next number represents a large discharge threshold that presumably was not reached during the missing years. The INF following the threshold discharge simply indicates the largest possible discharge during the missing years (infinitely large). The first column after the STATION and THRESHOLD rows indicates whether discharge is a single-valued discharge (Q) or an interval discharge (QINT). Second column is the water year for each discharge. For each single-valued discharge, the third column is the discharge in cubic feet per second, and for each interval discharge, the third and fourth columns represent the range in discharge in cubic feet per second. For each single-valued discharge, a value of 1 in the last column indicates that the discharge is a recorded, unregulated, discharge. A value of 2 in the last column indicates that the discharge was a recorded, regulated discharge]

Station - 11258099 Fresno River below Hidden Dam near Daulton, California (simulated unregulated peaks)

\begin{tabular}{|c|c|c|c|}
\hline Threshold & 1939-1941 & 17,500 -INF & \\
\hline Q & 1938 & 15,000 & 1 \\
\hline Q & 1942 & 2,580 & 1 \\
\hline Q & 1943 & 3,620 & 1 \\
\hline Q & 1944 & 2,670 & 1 \\
\hline Q & 1945 & 8,090 & 1 \\
\hline Q & 1946 & 2,460 & 1 \\
\hline Q & 1947 & 1,600 & 1 \\
\hline Q & 1948 & 2,470 & 1 \\
\hline Q & 1949 & 1,510 & 1 \\
\hline Q & 1950 & 1,180 & 1 \\
\hline Q & 1951 & 10,700 & 1 \\
\hline Q & 1952 & 5,020 & 1 \\
\hline Q & 1953 & 1,200 & 1 \\
\hline Q & 1954 & 723 & 1 \\
\hline Q & 1955 & 333 & 1 \\
\hline Q & 1956 & 17,500 & 1 \\
\hline Q & 1957 & 1,360 & 1 \\
\hline Q & 1958 & 10,400 & 1 \\
\hline Q & 1959 & 1,180 & 1 \\
\hline Q & 1960 & 616 & 1 \\
\hline Q & 1961 & 257 & 1 \\
\hline Q & 1962 & 5,340 & 1 \\
\hline Q & 1963 & 6,290 & 1 \\
\hline Q & 1964 & 278 & 1 \\
\hline Q & 1965 & 3,460 & 1 \\
\hline Q & 1966 & 882 & 1 \\
\hline Q & 1967 & 5,590 & 1 \\
\hline Q & 1968 & 273 & 1 \\
\hline Q & 1969 & 17,300 & 1 \\
\hline Q & 1970 & 4,420 & 1 \\
\hline Q & 1971 & 461 & 1 \\
\hline Q & 1972 & 367 & 1 \\
\hline Q & 1973 & 11,200 & 1 \\
\hline Q & 1974 & 8,620 & 1 \\
\hline Q & 1975 & 877 & 1 \\
\hline Q & 1976 & 249 & \\
\hline
\end{tabular}


Table A4. Estimated, unregulated annual peak discharge for key dam sites in the SacramentoSan Joaquin River Basin, California.-Continued

[For some stations, missing discharges are represented by interval discharge thresholds. These sites have a row of data after the STATION row with THRESHOLD indicated. The next two numbers in the THRESHOLD row show the first and last year of missing record. The next number represents a large discharge threshold that presumably was not reached during the missing years. The INF following the threshold discharge simply indicates the largest possible discharge during the missing years (infinitely large). The first column after the STATION and THRESHOLD rows indicates whether discharge is a single-valued discharge (Q) or an interval discharge (QINT). Second column is the water year for each discharge. For each single-valued discharge, the third column is the discharge in cubic feet per second, and for each interval discharge, the third and fourth columns represent the range in discharge in cubic feet per second. For each single-valued discharge, a value of 1 in the last column indicates that the discharge is a recorded, unregulated, discharge. A value of 2 in the last column indicates that the discharge was a recorded, regulated discharge]

Station - 11258099 Fresno River below Hidden Dam near Daulton, California (simulated unregulated peaks)-Continued

\begin{tabular}{lrr}
\hline Q & 1977 & 54.8 \\
Q & 1978 & 7,940 \\
Q & 1979 & 3,590 \\
Q & 1980 & 6,250 \\
Q & 1981 & 721 \\
Q & 1982 & 10,500 \\
Q & 1983 & 10,400 \\
Q & 1984 & 3,230 \\
Q & 1985 & 797 \\
Q & 1986 & 10,700 \\
Q & 1987 & 511 \\
Q & 1988 & 291 \\
Q & 1989 & 527 \\
Q & 1990 & 104 \\
Q & 1991 & 1,890 \\
Q & 1992 & 1,010 \\
Q & 1993 & 13,500 \\
Q & 1994 & 240 \\
Q & 1995 & 16,300 \\
Q & 1996 & 3,190 \\
Q & 1997 & 14,500 \\
Q & 1998 & 5,870 \\
Q & 1999 & 1,140 \\
\hline
\end{tabular}

Station - 11259099 Chowchilla River below Buchanan Dam near Raymond, California (simulated unregulated peaks)

\begin{tabular}{lrrr}
\hline Q & 1931 & 156 & 1 \\
Q & 1932 & 9,610 & 1 \\
Q & 1933 & 620 & 1 \\
Q & 1934 & 2,170 & 1 \\
Q & 1935 & 5,510 & 1 \\
Q & 1936 & 11,000 & 1 \\
Q & 1937 & 13,600 & 1 \\
Q & 1938 & 18,900 & 1 \\
Q & 1939 & 765 & 1 \\
Q & 1940 & 8,750 & 1 \\
Q & 1941 & 12,100 & 1 \\
Q & 1942 & 5,800 & 1
\end{tabular}


Table A4. Estimated, unregulated annual peak discharge for key dam sites in the SacramentoSan Joaquin River Basin, California.-Continued

[For some stations, missing discharges are represented by interval discharge thresholds. These sites have a row of data after the STATION row with THRESHOLD indicated. The next two numbers in the THRESHOLD row show the first and last year of missing record. The next number represents a large discharge threshold that presumably was not reached during the missing years. The INF following the threshold discharge simply indicates the largest possible discharge during the missing years (infinitely large). The first column after the STATION and THRESHOLD rows indicates whether discharge is a single-valued discharge (Q) or an interval discharge (QINT). Second column is the water year for each discharge. For each single-valued discharge, the third column is the discharge in cubic feet per second, and for each interval discharge, the third and fourth columns represent the range in discharge in cubic feet per second. For each single-valued discharge, a value of 1 in the last column indicates that the discharge is a recorded, unregulated, discharge. A value of 2 in the last column indicates that the discharge was a recorded, regulated discharge]

Station - 11259099 Chowchilla River below Buchanan Dam near Raymond, California (simulated unregulated peaks)—Continued

\begin{tabular}{|c|c|c|c|}
\hline Q & 1943 & 8,460 & 1 \\
\hline Q & 1944 & 5,020 & 1 \\
\hline Q & 1945 & 9,610 & 1 \\
\hline Q & 1946 & 3,450 & 1 \\
\hline Q & 1947 & 2,870 & 1 \\
\hline Q & 1948 & 5,660 & 1 \\
\hline Q & 1949 & 3,360 & 1 \\
\hline Q & 1950 & 4,250 & 1 \\
\hline Q & 1951 & 22,500 & 1 \\
\hline Q & 1952 & 6,040 & 1 \\
\hline Q & 1953 & 1,710 & 1 \\
\hline Q & 1954 & 1,390 & 1 \\
\hline Q & 1955 & 1,070 & 1 \\
\hline Q & 1956 & 30,000 & 1 \\
\hline Q & 1957 & 1,230 & 1 \\
\hline Q & 1958 & 14,000 & 1 \\
\hline Q & 1959 & 2,120 & 1 \\
\hline Q & 1960 & 1,620 & 1 \\
\hline Q & 1961 & 200 & 1 \\
\hline Q & 1962 & 6400 & 1 \\
\hline Q & 1963 & 9,740 & 1 \\
\hline Q & 1964 & 855 & 1 \\
\hline Q & 1965 & 8,380 & 1 \\
\hline Q & 1966 & 2,460 & 1 \\
\hline Q & 1967 & 6,880 & 1 \\
\hline Q & 1968 & 292 & 1 \\
\hline Q & 1969 & 13,700 & 1 \\
\hline Q & 1970 & 8,700 & 1 \\
\hline Q & 1971 & 574 & 1 \\
\hline Q & 1972 & 634 & 1 \\
\hline Q & 1973 & 11,200 & \\
\hline Q & 1974 & 8,440 & \\
\hline Q & 1975 & 2,650 & \\
\hline Q & 1976 & 391 & \\
\hline Q & 1977 & 43.5 & \\
\hline Q & 1978 & 10,300 & \\
\hline Q & 1979 & 4,990 & \\
\hline Q & 1980 & 6,310 & \\
\hline
\end{tabular}


Table A4. Estimated, unregulated annual peak discharge for key dam sites in the SacramentoSan Joaquin River Basin, California.-Continued

[For some stations, missing discharges are represented by interval discharge thresholds. These sites have a row of data after the STATION row with THRESHOLD indicated. The next two numbers in the THRESHOLD row show the first and last year of missing record. The next number represents a large discharge threshold that presumably was not reached during the missing years. The INF following the threshold discharge simply indicates the largest possible discharge during the missing years (infinitely large). The first column after the STATION and THRESHOLD rows indicates whether discharge is a single-valued discharge (Q) or an interval discharge (QINT). Second column is the water year for each discharge. For each single-valued discharge, the third column is the discharge in cubic feet per second, and for each interval discharge, the third and fourth columns represent the range in discharge in cubic feet per second. For each single-valued discharge, a value of 1 in the last column indicates that the discharge is a recorded, unregulated, discharge. A value of 2 in the last column indicates that the discharge was a recorded, regulated discharge]

Station - 11259099 Chowchilla River below Buchanan Dam near Raymond, California (simulated unregulated peaks)—Continued

\begin{tabular}{|c|c|c|c|}
\hline $\mathrm{Q}$ & 1981 & 2,150 & \\
\hline Q & 1982 & 16,600 & \\
\hline Q & 1983 & 15,800 & \\
\hline Q & 1984 & 5,350 & \\
\hline Q & 1985 & 1,600 & \\
\hline Q & 1986 & 14,900 & \\
\hline $\mathrm{Q}$ & 1987 & 849 & \\
\hline Q & 1988 & 233 & \\
\hline Q & 1989 & 893 & \\
\hline Q & 1990 & 106 & \\
\hline Q & 1991 & 2,830 & \\
\hline Q & 1992 & 2,800 & \\
\hline Q & 1993 & 16,700 & \\
\hline $\mathrm{Q}$ & 1994 & 249 & \\
\hline Q & 1995 & 17,700 & \\
\hline Q & 1996 & 5,060 & \\
\hline Q & 1997 & 17,600 & \\
\hline Q & 1998 & 8,350 & \\
\hline Q & 1999 & 2,180 & \\
\hline \multicolumn{4}{|c|}{ Station - 11270099 Merced River at Exchequer, California (simulated unregulated peaks) } \\
\hline Threshold & 1915-1915 & 107,000-INF & \\
\hline Q & 1902 & 9,120 & 1 \\
\hline Q & 1903 & 19,000 & 1 \\
\hline Q & 1904 & 10,700 & 1 \\
\hline Q & 1905 & 11,000 & 1 \\
\hline Q & 1906 & 26,600 & 1 \\
\hline Q & 1907 & 25,200 & 1 \\
\hline $\mathrm{Q}$ & 1908 & 3,970 & 1 \\
\hline Q & 1909 & 25,800 & 1 \\
\hline $\mathrm{Q}$ & 1910 & 18,700 & 1 \\
\hline Q & 1911 & 47,700 & 1 \\
\hline Q & 1912 & 6,840 & 1 \\
\hline $\mathrm{Q}$ & 1913 & 3,480 & 1 \\
\hline Q & 1914 & 206 & 1 \\
\hline Q & 1916 & 22,000 & 1 \\
\hline $\mathrm{Q}$ & 1917 & 21,700 & 1 \\
\hline $\mathrm{Q}$ & 1918 & 17,700 & 1 \\
\hline
\end{tabular}


Table A4. Estimated, unregulated annual peak discharge for key dam sites in the SacramentoSan Joaquin River Basin, California.-Continued

[For some stations, missing discharges are represented by interval discharge thresholds. These sites have a row of data after the STATION row with THRESHOLD indicated. The next two numbers in the THRESHOLD row show the first and last year of missing record. The next number represents a large discharge threshold that presumably was not reached during the missing years. The INF following the threshold discharge simply indicates the largest possible discharge during the missing years (infinitely large). The first column after the STATION and THRESHOLD rows indicates whether discharge is a single-valued discharge (Q) or an interval discharge (QINT). Second column is the water year for each discharge. For each single-valued discharge, the third column is the discharge in cubic feet per second, and for each interval discharge, the third and fourth columns represent the range in discharge in cubic feet per second. For each single-valued discharge, a value of 1 in the last column indicates that the discharge is a recorded, unregulated, discharge. A value of 2 in the last column indicates that the discharge was a recorded, regulated discharge]

Station - 11270099 Merced River at Exchequer, California (simulated unregulated peaks)—Cont.

\begin{tabular}{|c|c|c|c|}
\hline Q & 1919 & 9,580 & 1 \\
\hline Q & 1920 & 10,000 & 1 \\
\hline Q & 1921 & 19,400 & 1 \\
\hline Q & 1922 & 17,200 & 1 \\
\hline Q & 1923 & 11,500 & 1 \\
\hline Q & 1924 & 2,970 & 1 \\
\hline Q & 1925 & 15,400 & 1 \\
\hline Q & 1926 & 11,100 & 2 \\
\hline Q & 1927 & 10,900 & 1 \\
\hline Q & 1928 & 20,800 & 1 \\
\hline Q & 1929 & 7,150 & 1 \\
\hline Q & 1930 & 4,760 & 1 \\
\hline Q & 1931 & 2,840 & 1 \\
\hline Q & 1932 & 14,600 & 1 \\
\hline Q & 1933 & 7,440 & 1 \\
\hline Q & 1934 & 5,620 & 1 \\
\hline Q & 1935 & 29,200 & 1 \\
\hline Q & 1936 & 19,100 & 1 \\
\hline Q & 1937 & 33,800 & 1 \\
\hline Q & 1938 & 46,300 & 1 \\
\hline Q & 1939 & 4,140 & 1 \\
\hline Q & 1940 & 14,500 & 1 \\
\hline Q & 1941 & 17,500 & 1 \\
\hline Q & 1942 & 10,600 & 1 \\
\hline Q & 1943 & 17,400 & 1 \\
\hline Q & 1944 & 6,710 & 1 \\
\hline Q & 1945 & 45,000 & 1 \\
\hline Q & 1946 & 14,800 & 1 \\
\hline Q & 1947 & 6,470 & 1 \\
\hline Q & 1948 & 8,380 & 1 \\
\hline Q & 1949 & 7,750 & 1 \\
\hline Q & 1950 & 7,470 & 1 \\
\hline Q & 1951 & 64,700 & 1 \\
\hline Q & 1952 & 17,200 & 1 \\
\hline Q & 1953 & 6,590 & 1 \\
\hline Q & 1954 & 7,090 & 1 \\
\hline Q & 1955 & 6,530 & 1 \\
\hline Q & 1956 & 107,000 & 1 \\
\hline Q & 1957 & 11,700 & 1 \\
\hline
\end{tabular}


Table A4. Estimated, unregulated annual peak discharge for key dam sites in the SacramentoSan Joaquin River Basin, California.-Continued

[For some stations, missing discharges are represented by interval discharge thresholds. These sites have a row of data after the STATION row with THRESHOLD indicated. The next two numbers in the THRESHOLD row show the first and last year of missing record. The next number represents a large discharge threshold that presumably was not reached during the missing years. The INF following the threshold discharge simply indicates the largest possible discharge during the missing years (infinitely large). The first column after the STATION and THRESHOLD rows indicates whether discharge is a single-valued discharge (Q) or an interval discharge (QINT). Second column is the water year for each discharge. For each single-valued discharge, the third column is the discharge in cubic feet per second, and for each interval discharge, the third and fourth columns represent the range in discharge in cubic feet per second. For each single-valued discharge, a value of 1 in the last column indicates that the discharge is a recorded, unregulated, discharge. A value of 2 in the last column indicates that the discharge was a recorded, regulated discharge]

Station - 11270099 Merced River at Exchequer, California (simulated unregulated peaks)—Cont.

\begin{tabular}{|c|c|c|c|}
\hline Q & 1958 & 26,100 & 1 \\
\hline Q & 1959 & 8,310 & 1 \\
\hline Q & 1960 & 7,630 & 1 \\
\hline Q & 1961 & 3,330 & 1 \\
\hline Q & 1962 & 16,600 & 1 \\
\hline Q & 1963 & 52,700 & 1 \\
\hline Q & 1964 & 4,030 & 1 \\
\hline Q & 1965 & 45,100 & 1 \\
\hline Q & 1966 & 8,100 & 1 \\
\hline Q & 1967 & 22,500 & 1 \\
\hline Q & 1968 & 3,370 & 1 \\
\hline Q & 1969 & 45,600 & 1 \\
\hline Q & 1970 & 19,100 & 1 \\
\hline Q & 1971 & 6,010 & 1 \\
\hline Q & 1972 & 4,560 & 1 \\
\hline Q & 1973 & 16,400 & \\
\hline Q & 1974 & 14,100 & \\
\hline Q & 1975 & 13,100 & \\
\hline Q & 1976 & 2,770 & \\
\hline Q & 1977 & 2,600 & \\
\hline Q & 1978 & 19,600 & \\
\hline Q & 1979 & 17,400 & \\
\hline Q & 1980 & 42,600 & \\
\hline Q & 1981 & 5,750 & \\
\hline Q & 1982 & 53,800 & \\
\hline Q & 1983 & 28,300 & \\
\hline Q & 1984 & 23,400 & \\
\hline Q & 1985 & 5,130 & \\
\hline Q & 1986 & 43,400 & \\
\hline Q & 1987 & 3,640 & \\
\hline Q & 1988 & 3,200 & \\
\hline Q & 1989 & 4,920 & \\
\hline Q & 1990 & 3,180 & \\
\hline Q & 1991 & 5,760 & \\
\hline Q & 1992 & 5,590 & \\
\hline Q & 1993 & 17,800 & \\
\hline Q & 1994 & 3,740 & \\
\hline Q & 1995 & 52,500 & \\
\hline Q & 1996 & 21,200 & \\
\hline
\end{tabular}


Table A4. Estimated, unregulated annual peak discharge for key dam sites in the SacramentoSan Joaquin River Basin, California.-Continued

[For some stations, missing discharges are represented by interval discharge thresholds. These sites have a row of data after the STATION row with THRESHOLD indicated. The next two numbers in the THRESHOLD row show the first and last year of missing record. The next number represents a large discharge threshold that presumably was not reached during the missing years. The INF following the threshold discharge simply indicates the largest possible discharge during the missing years (infinitely large). The first column after the STATION and THRESHOLD rows indicates whether discharge is a single-valued discharge (Q) or an interval discharge (QINT). Second column is the water year for each discharge. For each single-valued discharge, the third column is the discharge in cubic feet per second, and for each interval discharge, the third and fourth columns represent the range in discharge in cubic feet per second. For each single-valued discharge, a value of 1 in the last column indicates that the discharge is a recorded, unregulated, discharge. A value of 2 in the last column indicates that the discharge was a recorded, regulated discharge]

Station - 11270099 Merced River at Exchequer, California (simulated unregulated peaks)—Cont.

\begin{tabular}{ccc}
\hline Q & 1997 & 95,200 \\
Q & 1998 & 22,000 \\
Q & 1999 & 10,800 \\
\hline
\end{tabular}

Station - 11288099 Tuolumne River above La Grange Dam near La Grange, California (simulated unregulated peaks)

\begin{tabular}{|c|c|c|c|}
\hline Threshold & $1863-1896$ & $130,000-I N F$ & \\
\hline Threshold & 2000-2006 & $153,000-I N F$ & \\
\hline Q & 1862 & 130,000 & 1 \\
\hline Q & 1897 & 20,000 & \\
\hline Q & 1898 & 9,290 & \\
\hline Q & 1899 & 33,200 & \\
\hline Q & 1900 & 17,500 & \\
\hline Q & 1901 & 27,900 & \\
\hline Q & 1902 & 14,900 & \\
\hline Q & 1903 & 24,400 & \\
\hline Q & 1904 & 20,200 & \\
\hline Q & 1905 & 17,900 & \\
\hline Q & 1906 & 32,500 & \\
\hline Q & 1907 & 63,000 & \\
\hline Q & 1908 & 7,900 & \\
\hline Q & 1909 & 33,100 & \\
\hline Q & 1910 & 25,800 & \\
\hline Q & 1911 & 65,700 & \\
\hline $\mathrm{Q}$ & 1912 & 17,000 & \\
\hline Q & 1913 & 9,280 & \\
\hline Q & 1914 & 38,900 & \\
\hline Q & 1915 & 18,800 & \\
\hline Q & 1916 & 21,100 & \\
\hline Q & 1917 & 28,500 & \\
\hline Q & 1918 & 18,700 & \\
\hline Q & 1919 & 17,000 & \\
\hline Q & 1920 & 15,900 & \\
\hline Q & 1921 & 15,300 & \\
\hline Q & 1922 & 22,700 & \\
\hline Q & 1923 & 17,600 & \\
\hline Q & 1924 & 10,700 & \\
\hline Q & 1925 & 22,200 & \\
\hline Q & 1928 & 54,100 & \\
\hline Q & 1929 & 18,800 & \\
\hline
\end{tabular}


Table A4. Estimated, unregulated annual peak discharge for key dam sites in the SacramentoSan Joaquin River Basin, California.-Continued

[For some stations, missing discharges are represented by interval discharge thresholds. These sites have a row of data after the STATION row with THRESHOLD indicated. The next two numbers in the THRESHOLD row show the first and last year of missing record. The next number represents a large discharge threshold that presumably was not reached during the missing years. The INF following the threshold discharge simply indicates the largest possible discharge during the missing years (infinitely large). The first column after the STATION and THRESHOLD rows indicates whether discharge is a single-valued discharge (Q) or an interval discharge (QINT). Second column is the water year for each discharge. For each single-valued discharge, the third column is the discharge in cubic feet per second, and for each interval discharge, the third and fourth columns represent the range in discharge in cubic feet per second. For each single-valued discharge, a value of 1 in the last column indicates that the discharge is a recorded, unregulated, discharge. A value of 2 in the last column indicates that the discharge was a recorded, regulated discharge]

\begin{tabular}{|c|c|c|}
\hline Q & 1930 & 10,300 \\
\hline Q & 1931 & 6,850 \\
\hline Q & 1932 & 28,400 \\
\hline Q & 1933 & 16,200 \\
\hline Q & 1934 & 7,590 \\
\hline Q & 1935 & 29,000 \\
\hline Q & 1936 & 27,000 \\
\hline Q & 1937 & 30,200 \\
\hline Q & 1938 & 93,400 \\
\hline Q & 1939 & 7,540 \\
\hline Q & 1940 & 36,500 \\
\hline Q & 1941 & 21,700 \\
\hline Q & 1942 & 28,100 \\
\hline Q & 1943 & 28,700 \\
\hline Q & 1944 & 12,000 \\
\hline Q & 1945 & 56,700 \\
\hline Q & 1946 & 23,400 \\
\hline Q & 1947 & 12,200 \\
\hline Q & 1948 & 15,500 \\
\hline Q & 1949 & 14,400 \\
\hline Q & 1950 & 14,800 \\
\hline Q & 1951 & 84,000 \\
\hline Q & 1952 & 21,000 \\
\hline Q & 1953 & 17,900 \\
\hline Q & 1954 & 21,000 \\
\hline Q & 1955 & 13,500 \\
\hline Q & 1956 & 153,000 \\
\hline Q & 1957 & 22,300 \\
\hline Q & 1958 & 23,300 \\
\hline Q & 1959 & 13,500 \\
\hline Q & 1960 & 12,900 \\
\hline Q & 1961 & 6,200 \\
\hline Q & 1962 & 20,300 \\
\hline Q & 1963 & 87,900 \\
\hline Q & 1964 & 13,000 \\
\hline Q & 1965 & 91,200 \\
\hline
\end{tabular}


Table A4. Estimated, unregulated annual peak discharge for key dam sites in the SacramentoSan Joaquin River Basin, California.-Continued

[For some stations, missing discharges are represented by interval discharge thresholds. These sites have a row of data after the STATION row with THRESHOLD indicated. The next two numbers in the THRESHOLD row show the first and last year of missing record. The next number represents a large discharge threshold that presumably was not reached during the missing years. The INF following the threshold discharge simply indicates the largest possible discharge during the missing years (infinitely large). The first column after the STATION and THRESHOLD rows indicates whether discharge is a single-valued discharge (Q) or an interval discharge (QINT). Second column is the water year for each discharge. For each single-valued discharge, the third column is the discharge in cubic feet per second, and for each interval discharge, the third and fourth columns represent the range in discharge in cubic feet per second. For each single-valued discharge, a value of 1 in the last column indicates that the discharge is a recorded, unregulated, discharge. A value of 2 in the last column indicates that the discharge was a recorded, regulated discharge]

\begin{tabular}{|c|c|c|}
\hline \multicolumn{3}{|c|}{$\begin{array}{l}\text { Station - } 11288099 \text { Tuolumne River above La Grange Dam near La Grange, California (simulated } \\
\text { unregulated peaks)—Continued }\end{array}$} \\
\hline $\mathrm{Q}$ & 1966 & 12,400 \\
\hline $\mathrm{Q}$ & 1967 & 37,300 \\
\hline $\mathrm{Q}$ & 1968 & 11,100 \\
\hline $\mathrm{Q}$ & 1969 & 62,200 \\
\hline $\mathrm{Q}$ & 1970 & 38,100 \\
\hline $\mathrm{Q}$ & 1971 & 12,100 \\
\hline $\mathrm{Q}$ & 1972 & 10,300 \\
\hline $\mathrm{Q}$ & 1973 & 20,600 \\
\hline $\mathrm{Q}$ & 1974 & 28,900 \\
\hline $\mathrm{Q}$ & 1975 & 78,600 \\
\hline $\mathrm{Q}$ & 1976 & 7,130 \\
\hline $\mathrm{Q}$ & 1977 & 7,040 \\
\hline $\mathrm{Q}$ & 1978 & 22,600 \\
\hline $\mathrm{Q}$ & 1979 & 24,700 \\
\hline $\mathrm{Q}$ & 1980 & 75,200 \\
\hline $\mathrm{Q}$ & 1981 & 11,000 \\
\hline $\mathrm{Q}$ & 1982 & 62,200 \\
\hline $\mathrm{Q}$ & 1983 & 32,700 \\
\hline Q & 1984 & 35,400 \\
\hline $\mathrm{Q}$ & 1985 & 11,000 \\
\hline $\mathrm{Q}$ & 1986 & 72,500 \\
\hline $\mathrm{Q}$ & 1987 & 8,880 \\
\hline $\mathrm{Q}$ & 1988 & 7,060 \\
\hline $\mathrm{Q}$ & 1989 & 14,800 \\
\hline $\mathrm{Q}$ & 1990 & 7,580 \\
\hline $\mathrm{Q}$ & 1991 & 13,400 \\
\hline $\mathrm{Q}$ & 1992 & 7,790 \\
\hline $\mathrm{Q}$ & 1993 & 18,700 \\
\hline $\mathrm{Q}$ & 1994 & 9,130 \\
\hline $\mathrm{Q}$ & 1995 & 58,200 \\
\hline $\mathrm{Q}$ & 1996 & 48,000 \\
\hline $\mathrm{Q}$ & 1997 & 148,000 \\
\hline $\mathrm{Q}$ & 1998 & 35,300 \\
\hline $\mathrm{Q}$ & 1999 & 20,500 \\
\hline
\end{tabular}


Table A4. Estimated, unregulated annual peak discharge for key dam sites in the SacramentoSan Joaquin River Basin, California._-Continued

[For some stations, missing discharges are represented by interval discharge thresholds. These sites have a row of data after the STATION row with THRESHOLD indicated. The next two numbers in the THRESHOLD row show the first and last year of missing record. The next number represents a large discharge threshold that presumably was not reached during the missing years. The INF following the threshold discharge simply indicates the largest possible discharge during the missing years (infinitely large). The first column after the STATION and THRESHOLD rows indicates whether discharge is a single-valued discharge (Q) or an interval discharge (QINT). Second column is the water year for each discharge. For each single-valued discharge, the third column is the discharge in cubic feet per second, and for each interval discharge, the third and fourth columns represent the range in discharge in cubic feet per second. For each single-valued discharge, a value of 1 in the last column indicates that the discharge is a recorded, unregulated, discharge. A value of 2 in the last column indicates that the discharge was a recorded, regulated discharge]

Station - 11299599 Stanislaus River below Melones powerhouse near Sonora, California (simulated unregulated peaks)

\begin{tabular}{|c|c|c|}
\hline Threshold & 2000-2006 & 102,000 -INF \\
\hline $\mathrm{Q}$ & 1932 & 11,200 \\
\hline Q & 1933 & 10,600 \\
\hline Q & 1934 & 3,260 \\
\hline Q & 1935 & 12,900 \\
\hline Q & 1936 & 17,900 \\
\hline Q & 1937 & 11,800 \\
\hline Q & 1938 & 46,400 \\
\hline Q & 1939 & 4,690 \\
\hline Q & 1940 & 25,800 \\
\hline Q & 1941 & 13,000 \\
\hline Q & 1942 & 13,200 \\
\hline Q & 1943 & 25,900 \\
\hline Q & 1944 & 8,150 \\
\hline Q & 1945 & 23,600 \\
\hline Q & 1946 & 9,310 \\
\hline Q & 1947 & 5,740 \\
\hline Q & 1948 & 11,700 \\
\hline Q & 1949 & 10,600 \\
\hline Q & 1950 & 9,490 \\
\hline Q & 1951 & 73,900 \\
\hline Q & 1952 & 14,700 \\
\hline Q & 1953 & 13,000 \\
\hline Q & 1954 & 14,100 \\
\hline Q & 1955 & 6,680 \\
\hline Q & 1956 & 102,000 \\
\hline Q & 1957 & 15,600 \\
\hline Q & 1958 & 16,300 \\
\hline Q & 1959 & 3,570 \\
\hline Q & 1960 & 9,680 \\
\hline Q & 1961 & 2,840 \\
\hline Q & 1962 & 8,290 \\
\hline Q & 1963 & 48,000 \\
\hline Q & 1964 & 4,730 \\
\hline Q & 1965 & 54,100 \\
\hline Q & 1966 & 4,630 \\
\hline Q & 1967 & 20,100 \\
\hline Q & 1968 & 6,080 \\
\hline Q & 1969 & 29,800 \\
\hline Q & 1970 & 35,100 \\
\hline $\mathrm{Q}$ & 1971 & 11,700 \\
\hline
\end{tabular}


Table A4. Estimated, unregulated annual peak discharge for key dam sites in the SacramentoSan Joaquin River Basin, California.-Continued

[For some stations, missing discharges are represented by interval discharge thresholds. These sites have a row of data after the STATION row with THRESHOLD indicated. The next two numbers in the THRESHOLD row show the first and last year of missing record. The next number represents a large discharge threshold that presumably was not reached during the missing years. The INF following the threshold discharge simply indicates the largest possible discharge during the missing years (infinitely large). The first column after the STATION and THRESHOLD rows indicates whether discharge is a single-valued discharge (Q) or an interval discharge (QINT). Second column is the water year for each discharge. For each single-valued discharge, the third column is the discharge in cubic feet per second, and for each interval discharge, the third and fourth columns represent the range in discharge in cubic feet per second. For each single-valued discharge, a value of 1 in the last column indicates that the discharge is a recorded, unregulated, discharge. A value of 2 in the last column indicates that the discharge was a recorded, regulated discharge]

Station - 11299599 Stanislaus River below Melones powerhouse near Sonora, California (simulated unregulated peaks) - Continued

\begin{tabular}{|c|c|c|}
\hline $\mathrm{Q}$ & 1972 & 5,130 \\
\hline $\mathrm{Q}$ & 1973 & 15,500 \\
\hline $\mathrm{Q}$ & 1974 & 12,000 \\
\hline Q & 1975 & 22,500 \\
\hline $\mathrm{Q}$ & 1976 & 2,220 \\
\hline $\mathrm{Q}$ & 1977 & 1,130 \\
\hline $\mathrm{Q}$ & 1978 & 28,100 \\
\hline $\mathrm{Q}$ & 1979 & 11,300 \\
\hline $\mathrm{Q}$ & 1980 & 57,200 \\
\hline $\mathrm{Q}$ & 1981 & 6,860 \\
\hline $\mathrm{Q}$ & 1982 & 53,900 \\
\hline Q & 1983 & 22,800 \\
\hline $\mathrm{Q}$ & 1984 & 23,300 \\
\hline $\mathrm{Q}$ & 1985 & 6,290 \\
\hline $\mathrm{Q}$ & 1986 & 56,900 \\
\hline $\mathrm{Q}$ & 1987 & 4,220 \\
\hline Q & 1988 & 1,910 \\
\hline Q & 1989 & 8,070 \\
\hline $\mathrm{Q}$ & 1990 & 2,750 \\
\hline $\mathrm{Q}$ & 1991 & 6,840 \\
\hline $\mathrm{Q}$ & 1992 & 3,840 \\
\hline Q & 1993 & 10,400 \\
\hline Q & 1994 & 2,910 \\
\hline $\mathrm{Q}$ & 1995 & 30,000 \\
\hline $\mathrm{Q}$ & 1996 & 26,300 \\
\hline $\mathrm{Q}$ & 1997 & 92,000 \\
\hline $\mathrm{Q}$ & 1998 & 14,500 \\
\hline Q & 1999 & 13,600 \\
\hline \multicolumn{3}{|c|}{$\begin{array}{l}\text { Station - } 11308999 \text { Calaveras River below New Hogan Dam near Valley Springs, California (simulate } \\
\text { unregulated peaks) }\end{array}$} \\
\hline $\mathrm{Q}$ & 1964 & 3,710 \\
\hline Q & 1965 & 19,000 \\
\hline Q & 1966 & 2,830 \\
\hline $\mathrm{Q}$ & 1967 & 9,800 \\
\hline $\mathrm{Q}$ & 1968 & 2,290 \\
\hline $\mathrm{Q}$ & 1969 & 21,900 \\
\hline $\mathrm{Q}$ & 1970 & 10,500 \\
\hline
\end{tabular}


Table A4. Estimated, unregulated annual peak discharge for key dam sites in the SacramentoSan Joaquin River Basin, California.-Continued

[For some stations, missing discharges are represented by interval discharge thresholds. These sites have a row of data after the STATION row with THRESHOLD indicated. The next two numbers in the THRESHOLD row show the first and last year of missing record. The next number represents a large discharge threshold that presumably was not reached during the missing years. The INF following the threshold discharge simply indicates the largest possible discharge during the missing years (infinitely large). The first column after the STATION and THRESHOLD rows indicates whether discharge is a single-valued discharge (Q) or an interval discharge (QINT). Second column is the water year for each discharge. For each single-valued discharge, the third column is the discharge in cubic feet per second, and for each interval discharge, the third and fourth columns represent the range in discharge in cubic feet per second. For each single-valued discharge, a value of 1 in the last column indicates that the discharge is a recorded, unregulated, discharge. A value of 2 in the last column indicates that the discharge was a recorded, regulated discharge]

Station - 11308999 Calaveras River below New Hogan Dam near Valley Springs, California (simulated unregulated peaks)-Continued

\begin{tabular}{|c|c|c|c|}
\hline Q & 1971 & 4,230 & \\
\hline Q & 1972 & 7,090 & \\
\hline Q & 1973 & 11,200 & \\
\hline Q & 1974 & 13,400 & \\
\hline Q & 1975 & 8,370 & \\
\hline Q & 1976 & 315 & \\
\hline Q & 1977 & 144 & \\
\hline Q & 1978 & 8,350 & \\
\hline Q & 1979 & 7,780 & \\
\hline Q & 1980 & 12,700 & \\
\hline Q & 1981 & 4,490 & \\
\hline Q & 1982 & 18,300 & \\
\hline Q & 1983 & 15,400 & \\
\hline Q & 1984 & 11700 & \\
\hline Q & 1985 & 5,390 & \\
\hline Q & 1986 & 35,500 & \\
\hline Q & 1987 & 2,460 & \\
\hline Q & 1988 & 538 & \\
\hline Q & 1989 & 1,270 & \\
\hline Q & 1990 & 943 & \\
\hline Q & 1991 & 5,640 & \\
\hline Q & 1992 & 7,380 & \\
\hline Q & 1993 & 7,680 & \\
\hline Q & 1994 & 1,240 & \\
\hline Q & 1995 & 14,900 & \\
\hline Q & 1996 & 8,180 & \\
\hline Q & 1997 & 25,100 & \\
\hline Q & 1998 & 25,300 & \\
\hline \multicolumn{4}{|c|}{ Station - 11323599 Mokelumne River below Camanche Dam, California (simulated unregulated peaks) } \\
\hline Threshold & 1998-2006 & $97,200-I N F$ & \\
\hline Q & 1905 & 5,540 & 1 \\
\hline Q & 1906 & 9,960 & 1 \\
\hline Q & 1907 & 25,500 & 1 \\
\hline Q & 1908 & 3,100 & 1 \\
\hline Q & 1909 & 13,100 & 1 \\
\hline Q & 1910 & 10,800 & 1 \\
\hline Q & 1911 & 18,900 & 1 \\
\hline
\end{tabular}


Table A4. Estimated, unregulated annual peak discharge for key dam sites in the SacramentoSan Joaquin River Basin, California.-Continued

[For some stations, missing discharges are represented by interval discharge thresholds. These sites have a row of data after the STATION row with THRESHOLD indicated. The next two numbers in the THRESHOLD row show the first and last year of missing record. The next number represents a large discharge threshold that presumably was not reached during the missing years. The INF following the threshold discharge simply indicates the largest possible discharge during the missing years (infinitely large). The first column after the STATION and THRESHOLD rows indicates whether discharge is a single-valued discharge $(\mathrm{Q})$ or an interval discharge (QINT). Second column is the water year for each discharge. For each single-valued discharge, the third column is the discharge in cubic feet per second, and for each interval discharge, the third and fourth columns represent the range in discharge in cubic feet per second. For each single-valued discharge, a value of 1 in the last column indicates that the discharge is a recorded, unregulated, discharge. A value of 2 in the last column indicates that the discharge was a recorded, regulated discharge]

Station - 11323599 Mokelumne River below Camanche Dam, California (simulated unregulated peaks)-Continued

\begin{tabular}{|c|c|c|c|}
\hline Q & 1912 & 6,520 & 1 \\
\hline Q & 1913 & 5,580 & 1 \\
\hline Q & 1914 & 13,300 & 1 \\
\hline Q & 1915 & 8,290 & 1 \\
\hline Q & 1916 & 10,700 & 1 \\
\hline Q & 1917 & 9,300 & 1 \\
\hline Q & 1918 & 8,620 & 1 \\
\hline Q & 1919 & 7,540 & 1 \\
\hline Q & 1920 & 6,820 & 1 \\
\hline Q & 1921 & 11,100 & 1 \\
\hline Q & 1922 & 8,970 & 1 \\
\hline Q & 1923 & 6,400 & 1 \\
\hline Q & 1924 & 2,260 & 1 \\
\hline Q & 1925 & 18,500 & 1 \\
\hline Q & 1926 & 3,740 & 1 \\
\hline Q & 1927 & 7,870 & 1 \\
\hline Q & 1928 & 25,600 & 1 \\
\hline Q & 1929 & 4,340 & \\
\hline Q & 1930 & 4,080 & \\
\hline Q & 1931 & 2,470 & \\
\hline Q & 1932 & 6,950 & \\
\hline Q & 1933 & 6,310 & \\
\hline Q & 1934 & 3,510 & \\
\hline Q & 1935 & 7,690 & \\
\hline Q & 1936 & 18,800 & \\
\hline Q & 1937 & 7,670 & \\
\hline Q & 1938 & 28,900 & \\
\hline Q & 1939 & 3,150 & \\
\hline Q & 1940 & 13,400 & \\
\hline Q & 1941 & 7,690 & \\
\hline Q & 1942 & 13,000 & \\
\hline Q & 1943 & 14,200 & \\
\hline Q & 1944 & 4,880 & \\
\hline Q & 1945 & 16,100 & \\
\hline Q & 1946 & 7,590 & \\
\hline Q & 1947 & 4,980 & \\
\hline Q & 1948 & 6,690 & \\
\hline Q & 1949 & 6,310 & \\
\hline
\end{tabular}


Table A4. Estimated, unregulated annual peak discharge for key dam sites in the SacramentoSan Joaquin River Basin, California.-Continued

[For some stations, missing discharges are represented by interval discharge thresholds. These sites have a row of data after the STATION row with THRESHOLD indicated. The next two numbers in the THRESHOLD row show the first and last year of missing record. The next number represents a large discharge threshold that presumably was not reached during the missing years. The INF following the threshold discharge simply indicates the largest possible discharge during the missing years (infinitely large). The first column after the STATION and THRESHOLD rows indicates whether discharge is a single-valued discharge (Q) or an interval discharge (QINT). Second column is the water year for each discharge. For each single-valued discharge, the third column is the discharge in cubic feet per second, and for each interval discharge, the third and fourth columns represent the range in discharge in cubic feet per second. For each single-valued discharge, a value of 1 in the last column indicates that the discharge is a recorded, unregulated, discharge. A value of 2 in the last column indicates that the discharge was a recorded, regulated discharge]

Station - 11323599 Mokelumne River below Camanche Dam, California (simulated unregulated peaks)-Continued

\begin{tabular}{|c|c|c|}
\hline Q & 1950 & 6,460 \\
\hline Q & 1951 & 39,000 \\
\hline Q & 1952 & 9,240 \\
\hline Q & 1953 & 6,600 \\
\hline Q & 1954 & 6,790 \\
\hline Q & 1955 & 5,160 \\
\hline Q & 1956 & 43,800 \\
\hline Q & 1957 & 9,780 \\
\hline Q & 1958 & 12,000 \\
\hline Q & 1959 & 3,330 \\
\hline Q & 1960 & 6,710 \\
\hline Q & 1961 & 2,620 \\
\hline Q & 1962 & 6,480 \\
\hline Q & 1963 & 37,700 \\
\hline Q & 1964 & 4,080 \\
\hline Q & 1965 & 45,700 \\
\hline Q & 1966 & 3,490 \\
\hline Q & 1967 & 10,800 \\
\hline Q & 1968 & 4,120 \\
\hline Q & 1969 & 19,300 \\
\hline Q & 1970 & 18,500 \\
\hline Q & 1971 & 6,590 \\
\hline Q & 1972 & 4,700 \\
\hline Q & 1973 & 7,410 \\
\hline Q & 1974 & 9,820 \\
\hline Q & 1975 & 8,340 \\
\hline Q & 1976 & 2,880 \\
\hline Q & 1977 & 1,360 \\
\hline Q & 1978 & 7,690 \\
\hline Q & 1979 & 7,790 \\
\hline Q & 1980 & 40,300 \\
\hline Q & 1981 & 6,020 \\
\hline Q & 1982 & 31,000 \\
\hline Q & 1983 & 15,400 \\
\hline Q & 1984 & 16,900 \\
\hline Q & 1985 & 4,640 \\
\hline Q & 1986 & 35,100 \\
\hline Q & 1987 & 3,300 \\
\hline
\end{tabular}


Table A4. Estimated, unregulated annual peak discharge for key dam sites in the SacramentoSan Joaquin River Basin, California.-Continued

[For some stations, missing discharges are represented by interval discharge thresholds. These sites have a row of data after the STATION row with THRESHOLD indicated. The next two numbers in the THRESHOLD row show the first and last year of missing record. The next number represents a large discharge threshold that presumably was not reached during the missing years. The INF following the threshold discharge simply indicates the largest possible discharge during the missing years (infinitely large). The first column after the STATION and THRESHOLD rows indicates whether discharge is a single-valued discharge $(\mathrm{Q})$ or an interval discharge (QINT). Second column is the water year for each discharge. For each single-valued discharge, the third column is the discharge in cubic feet per second, and for each interval discharge, the third and fourth columns represent the range in discharge in cubic feet per second. For each single-valued discharge, a value of 1 in the last column indicates that the discharge is a recorded, unregulated, discharge. A value of 2 in the last column indicates that the discharge was a recorded, regulated discharge]

Station - 11323599 Mokelumne River below Camanche Dam, California (simulated unregulated peaks)-Continued

\begin{tabular}{|c|c|c|c|}
\hline Q & 1988 & \multicolumn{2}{|l|}{2,760} \\
\hline Q & 1989 & \multicolumn{2}{|l|}{6,790} \\
\hline Q & 1990 & \multicolumn{2}{|l|}{2,780} \\
\hline Q & 1991 & \multicolumn{2}{|l|}{5,740} \\
\hline Q & 1992 & \multicolumn{2}{|l|}{4,050} \\
\hline Q & 1993 & \multicolumn{2}{|l|}{7,750} \\
\hline Q & 1994 & \multicolumn{2}{|l|}{3,420} \\
\hline Q & 1995 & \multicolumn{2}{|l|}{19,600} \\
\hline Q & 1996 & \multicolumn{2}{|l|}{22,600} \\
\hline Q & 1997 & \multicolumn{2}{|l|}{97,200} \\
\hline \multicolumn{4}{|c|}{ Station - 11335099 Cosumnes River at Michigan Bar, California (simulated unregulated peaks) } \\
\hline Threshold & 1998-2006 & \multicolumn{2}{|c|}{ 95,600-INF } \\
\hline Q & 1907 & 71,000 & 1 \\
\hline Q & 1908 & 2,200 & 1 \\
\hline Q & 1909 & 28,400 & 1 \\
\hline Q & 1910 & 9,640 & 1 \\
\hline Q & 1911 & 28,400 & 1 \\
\hline Q & 1912 & 1,700 & 1 \\
\hline Q & 1913 & 1,700 & 1 \\
\hline Q & 1914 & 18,200 & 1 \\
\hline Q & 1915 & 8,200 & 1 \\
\hline Q & 1916 & 10,400 & 1 \\
\hline Q & 1917 & 22,900 & 1 \\
\hline Q & 1918 & 11,900 & 1 \\
\hline Q & 1919 & 22,000 & 1 \\
\hline Q & 1920 & 3,700 & 1 \\
\hline Q & 1921 & 20,600 & 1 \\
\hline Q & 1922 & 10,600 & 1 \\
\hline Q & 1923 & 11,600 & 1 \\
\hline Q & 1924 & 1,120 & 1 \\
\hline Q & 1925 & 23,800 & 1 \\
\hline Q & 1926 & 3,850 & 1 \\
\hline Q & 1927 & 11,400 & 1 \\
\hline Q & 1928 & 22,900 & 1 \\
\hline Q & 1929 & 3,160 & 1 \\
\hline Q & 1930 & 6,090 & 1 \\
\hline $\mathrm{Q}$ & 1931 & 1,620 & 1 \\
\hline
\end{tabular}


Table A4. Estimated, unregulated annual peak discharge for key dam sites in the SacramentoSan Joaquin River Basin, California.-Continued

[For some stations, missing discharges are represented by interval discharge thresholds. These sites have a row of data after the STATION row with THRESHOLD indicated. The next two numbers in the THRESHOLD row show the first and last year of missing record. The next number represents a large discharge threshold that presumably was not reached during the missing years. The INF following the threshold discharge simply indicates the largest possible discharge during the missing years (infinitely large). The first column after the STATION and THRESHOLD rows indicates whether discharge is a single-valued discharge (Q) or an interval discharge (QINT) Second column is the water year for each discharge. For each single-valued discharge, the third column is the discharge in cubic feet per second, and for each interval discharge, the third and fourth columns represent the range in discharge in cubic feet per second. For each single-valued discharge, a value of 1 in the last column indicates that the discharge is a recorded, unregulated, discharge. A value of 2 in the last column indicates that the discharge was a recorded, regulated discharge]

Station - 11335099 Cosumnes River at Michigan Bar, California (simulated unregulated peaks)— Continued

Q

Q

Q

Q

Q

Q

Q

Q

Q

Q

Q

Q

Q

Q

Q

Q

Q

Q

Q

Q

Q

Q

Q

Q

Q

Q

Q

Q

Q

Q

Q

Q

Q

Q

Q

Q

Q

Q

Q
1932

1933

1934

1935

1936

1937

1938

1939

1940

1941

1942

1943

1944

1945

1946

1947

1948

1949

1950

1951

1952

1953

1954

1955

1956

1957

1958

1959

1960

1961

1962

1963

1964

1965

1966

1967

1968

1969

1970
10,600

890

7,170

20,100

18,200

15,300

19,300

1,930

26,200

9,280

24,500

22,900

8,490

21,100

12,600

3,930

6,240

13,500

8,360

27,600

12,500

4,080

3,860

4,460

49,700

9,440

30,000

4,340

1,1200

625

8,880

41,600

4,170

45,200

2,880

15,900

4,930

28,900

16,900
2

2 
Table A4. Estimated, unregulated annual peak discharge for key dam sites in the SacramentoSan Joaquin River Basin, California._-Continued

[For some stations, missing discharges are represented by interval discharge thresholds. These sites have a row of data after the STATION row with THRESHOLD indicated. The next two numbers in the THRESHOLD row show the first and last year of missing record. The next number represents a large discharge threshold that presumably was not reached during the missing years. The INF following the threshold discharge simply indicates the largest possible discharge during the missing years (infinitely large). The first column after the STATION and THRESHOLD rows indicates whether discharge is a single-valued discharge (Q) or an interval discharge (QINT). Second column is the water year for each discharge. For each single-valued discharge, the third column is the discharge in cubic feet per second, and for each interval discharge, the third and fourth columns represent the range in discharge in cubic feet per second. For each single-valued discharge, a value of 1 in the last column indicates that the discharge is a recorded, unregulated, discharge. A value of 2 in the last column indicates that the discharge was a recorded, regulated discharge]

Station - 11335099 Cosumnes River at Michigan Bar, California (simulated unregulated peaks) Continued

\begin{tabular}{|c|c|c|c|}
\hline Q & 1971 & 8,590 & 2 \\
\hline $\mathrm{Q}$ & 1972 & 4,430 & \\
\hline $\mathrm{Q}$ & 1973 & 15,000 & 2 \\
\hline Q & 1974 & 9,610 & \\
\hline Q & 1975 & 11,000 & 2 \\
\hline Q & 1976 & 457 & \\
\hline Q & 1977 & 219 & \\
\hline $\mathrm{Q}$ & 1978 & 9,340 & \\
\hline $\mathrm{Q}$ & 1979 & 6,990 & 2 \\
\hline Q & 1980 & 34,200 & 2 \\
\hline Q & 1981 & 5,890 & 2 \\
\hline Q & 1982 & 38,600 & \\
\hline $\mathrm{Q}$ & 1983 & 27,500 & \\
\hline $\mathrm{Q}$ & 1984 & 21,000 & \\
\hline Q & 1985 & 6,290 & 2 \\
\hline Q & 1986 & 54,700 & \\
\hline $\mathrm{Q}$ & 1987 & 2,110 & \\
\hline Q & 1988 & 1,350 & \\
\hline Q & 1989 & 8,400 & \\
\hline Q & 1990 & 1,420 & \\
\hline Q & 1991 & 6670 & 2 \\
\hline Q & 1992 & 5340 & 2 \\
\hline Q & 1993 & 11,000 & \\
\hline Q & 1994 & 1,260 & \\
\hline Q & 1995 & 27,200 & \\
\hline Q & 1996 & 11,500 & \\
\hline Q & 1997 & 95,600 & \\
\hline
\end{tabular}

Station - 11344099 Littlejohns Creek below Farmington Reservoir (simulated unregulated peaks; U.S. Army Corps of Engineers station)

\begin{tabular}{lrr}
\hline Q & 1951 & 7,870 \\
Q & 1952 & 7,460 \\
Q & 1953 & 1,020 \\
Q & 1954 & 1,010 \\
Q & 1955 & 5,230 \\
Q & 1956 & 12,800 \\
Q & 1957 & 3,240 \\
Q & 1958 & 10,900 \\
Q & 1959 & 2,030 \\
Q & 1960 & 2,000
\end{tabular}


Table A4. Estimated, unregulated annual peak discharge for key dam sites in the SacramentoSan Joaquin River Basin, California.-Continued

[For some stations, missing discharges are represented by interval discharge thresholds. These sites have a row of data after the STATION row with THRESHOLD indicated. The next two numbers in the THRESHOLD row show the first and last year of missing record. The next number represents a large discharge threshold that presumably was not reached during the missing years. The INF following the threshold discharge simply indicates the largest possible discharge during the missing years (infinitely large). The first column after the STATION and THRESHOLD rows indicates whether discharge is a single-valued discharge (Q) or an interval discharge (QINT). Second column is the water year for each discharge. For each single-valued discharge, the third column is the discharge in cubic feet per second, and for each interval discharge, the third and fourth columns represent the range in discharge in cubic feet per second. For each single-valued discharge, a value of 1 in the last column indicates that the discharge is a recorded, unregulated, discharge. A value of 2 in the last column indicates that the discharge was a recorded, regulated discharge]

Station - 11344099 Littlejohns Creek below Farmington Reservoir (simulated unregulated peaks; U.S. Army Corps of Engineers station)—Continued

\begin{tabular}{|c|c|c|}
\hline Q & 1961 & 135 \\
\hline Q & 1962 & 7,560 \\
\hline Q & 1963 & 4,700 \\
\hline $\mathrm{Q}$ & 1964 & 1,270 \\
\hline Q & 1965 & 13,200 \\
\hline Q & 1966 & 3,000 \\
\hline Q & 1967 & 6,400 \\
\hline Q & 1968 & 1,770 \\
\hline Q & 1969 & 5,460 \\
\hline Q & 1970 & 5,830 \\
\hline Q & 1971 & 3,820 \\
\hline Q & 1972 & 1,810 \\
\hline Q & 1973 & 8,000 \\
\hline Q & 1974 & 7,050 \\
\hline $\mathrm{Q}$ & 1975 & 4,000 \\
\hline Q & 1976 & 12.3 \\
\hline Q & 1977 & 0 \\
\hline Q & 1978 & 5,070 \\
\hline $\mathrm{Q}$ & 1979 & 7,550 \\
\hline Q & 1980 & 7,310 \\
\hline Q & 1981 & 5,740 \\
\hline Q & 1982 & 9,770 \\
\hline Q & 1983 & 9,920 \\
\hline Q & 1984 & 8,590 \\
\hline Q & 1985 & 3,500 \\
\hline Q & 1986 & 14,500 \\
\hline Q & 1987 & 4,230 \\
\hline $\mathrm{Q}$ & 1988 & 81.9 \\
\hline Q & 1989 & 57.9 \\
\hline $\mathrm{Q}$ & 1990 & 31.6 \\
\hline Q & 1991 & 3,970 \\
\hline Q & 1992 & 6,690 \\
\hline Q & 1993 & 3,930 \\
\hline Q & 1994 & 382 \\
\hline $\mathrm{Q}$ & 1995 & 7,210 \\
\hline Q & 1996 & 5,810 \\
\hline Q & 1997 & 1,1700 \\
\hline Q & 1998 & 1,7200 \\
\hline Q & 1999 & 6,690 \\
\hline
\end{tabular}


Table A4. Estimated, unregulated annual peak discharge for key dam sites in the SacramentoSan Joaquin River Basin, California.—Continued

[For some stations, missing discharges are represented by interval discharge thresholds. These sites have a row of data after the STATION row with THRESHOLD indicated. The next two numbers in the THRESHOLD row show the first and last year of missing record. The next number represents a large discharge threshold that presumably was not reached during the missing years. The INF following the threshold discharge simply indicates the largest possible discharge during the missing years (infinitely large). The first column after the STATION and THRESHOLD rows indicates whether discharge is a single-valued discharge (Q) or an interval discharge (QINT). Second column is the water year for each discharge. For each single-valued discharge, the third column is the discharge in cubic feet per second, and for each interval discharge, the third and fourth columns represent the range in discharge in cubic feet per second. For each single-valued discharge, a value of 1 in the last column indicates that the discharge is a recorded, unregulated, discharge. A value of 2 in the last column indicates that the discharge was a recorded, regulated discharge]

\begin{tabular}{|c|c|c|c|}
\hline \multicolumn{4}{|c|}{ Station - 11370599 Sacramento River at Keswick, California (simulated unregulated peaks) } \\
\hline Threshold & 1999-2006 & $237,000-1$ & \\
\hline Q & 1926 & 66,000 & 1 \\
\hline Q & 1927 & 92,800 & 1 \\
\hline Q & 1928 & 94,900 & 1 \\
\hline Q & 1929 & 25,800 & 1 \\
\hline Q & 1930 & 64,000 & 1 \\
\hline Q & 1931 & 14,300 & 1 \\
\hline Q & 1932 & 45,400 & 1 \\
\hline Q & 1933 & 44,200 & 1 \\
\hline Q & 1934 & 38,900 & 1 \\
\hline Q & 1935 & 56,800 & 1 \\
\hline Q & 1936 & 85,500 & 1 \\
\hline Q & 1937 & 38,400 & 1 \\
\hline Q & 1938 & 132,000 & 1 \\
\hline Q & 1939 & 48,800 & 1 \\
\hline Q & 1940 & 186,000 & 1 \\
\hline Q & 1941 & 86,800 & 1 \\
\hline Q & 1942 & 96,100 & 1 \\
\hline Q & 1943 & 56,400 & 1 \\
\hline Q & 1944 & 10,200 & \\
\hline Q & 1945 & 13,900 & \\
\hline Q & 1946 & 37,500 & \\
\hline Q & 1947 & 44,200 & \\
\hline Q & 1948 & 77,100 & \\
\hline Q & 1949 & 54,200 & \\
\hline Q & 1950 & 38,600 & \\
\hline Q & 1951 & 64,900 & \\
\hline Q & 1952 & 93,200 & \\
\hline Q & 1953 & 98,000 & \\
\hline Q & 1954 & 75,900 & \\
\hline Q & 1955 & 41,900 & \\
\hline Q & 1956 & 161,000 & \\
\hline Q & 1957 & 93,400 & \\
\hline Q & 1958 & 99,600 & \\
\hline Q & 1959 & 79,200 & \\
\hline Q & 1960 & 80,000 & \\
\hline Q & 1961 & 55,200 & \\
\hline Q & 1962 & 85,500 & \\
\hline Q & 1963 & 76,200 & \\
\hline
\end{tabular}


Table A4. Estimated, unregulated annual peak discharge for key dam sites in the SacramentoSan Joaquin River Basin, California.-Continued

[For some stations, missing discharges are represented by interval discharge thresholds. These sites have a row of data after the STATION row with THRESHOLD indicated. The next two numbers in the THRESHOLD row show the first and last year of missing record. The next number represents a large discharge threshold that presumably was not reached during the missing years. The INF following the threshold discharge simply indicates the largest possible discharge during the missing years (infinitely large). The first column after the STATION and THRESHOLD rows indicates whether discharge is a single-valued discharge (Q) or an interval discharge (QINT). Second column is the water year for each discharge. For each single-valued discharge, the third column is the discharge in cubic feet per second, and for each interval discharge, the third and fourth columns represent the range in discharge in cubic feet per second. For each single-valued discharge, a value of 1 in the last column indicates that the discharge is a recorded, unregulated, discharge. A value of 2 in the last column indicates that the discharge was a recorded, regulated discharge]

Station - 11370599 Sacramento River at Keswick, California (simulated unregulated peaks)— Continued

\begin{tabular}{|c|c|c|}
\hline Q & 1964 & 77,400 \\
\hline Q & 1965 & 190,000 \\
\hline Q & 1966 & 48,000 \\
\hline Q & 1967 & 77,000 \\
\hline Q & 1968 & 61,200 \\
\hline Q & 1969 & 109,000 \\
\hline Q & 1970 & 185,000 \\
\hline Q & 1971 & 76,700 \\
\hline Q & 1972 & 49,300 \\
\hline Q & 1973 & 90,300 \\
\hline Q & 1974 & 212,000 \\
\hline Q & 1975 & 70,000 \\
\hline Q & 1976 & 30,700 \\
\hline Q & 1977 & 12,400 \\
\hline Q & 1978 & 113,000 \\
\hline Q & 1979 & 40,200 \\
\hline Q & 1980 & 107,000 \\
\hline Q & 1981 & 40,100 \\
\hline Q & 1982 & 98,200 \\
\hline Q & 1983 & 110,000 \\
\hline Q & 1984 & 81,000 \\
\hline Q & 1985 & 32,200 \\
\hline Q & 1986 & 146,000 \\
\hline Q & 1987 & 50,900 \\
\hline Q & 1988 & 43,000 \\
\hline Q & 1989 & 8,860 \\
\hline Q & 1990 & 41,300 \\
\hline Q & 1991 & 38,300 \\
\hline Q & 1992 & 46,200 \\
\hline Q & 1993 & 98,700 \\
\hline Q & 1994 & 24,800 \\
\hline Q & 1995 & 130,000 \\
\hline Q & 1996 & 83,900 \\
\hline Q & 1997 & 237,000 \\
\hline Q & 1998 & 947,00 \\
\hline
\end{tabular}


Table A4. Estimated, unregulated annual peak discharge for key dam sites in the SacramentoSan Joaquin River Basin, California.-Continued

[For some stations, missing discharges are represented by interval discharge thresholds. These sites have a row of data after the STATION row with THRESHOLD indicated. The next two numbers in the THRESHOLD row show the first and last year of missing record. The next number represents a large discharge threshold that presumably was not reached during the missing years. The INF following the threshold discharge simply indicates the largest possible discharge during the missing years (infinitely large). The first column after the STATION and THRESHOLD rows indicates whether discharge is a single-valued discharge (Q) or an interval discharge (QINT). Second column is the water year for each discharge. For each single-valued discharge, the third column is the discharge in cubic feet per second, and for each interval discharge, the third and fourth columns represent the range in discharge in cubic feet per second. For each single-valued discharge, a value of 1 in the last column indicates that the discharge is a recorded, unregulated, discharge. A value of 2 in the last column indicates that the discharge was a recorded, regulated discharge]

Station - 11388099 Stony Creek below Black Butte Dam near Orland, California (simulated unregulated peaks)

\begin{tabular}{|c|c|c|}
\hline & 1964 & 5,230 \\
\hline ) & 1965 & 66,200 \\
\hline ) & 1966 & 26,100 \\
\hline 2 & 1967 & 20,300 \\
\hline Q & 1968 & 13,900 \\
\hline Q & 1969 & 23,700 \\
\hline Q & 1970 & 40,700 \\
\hline Q & 1971 & 20,100 \\
\hline Q & 1972 & 5,570 \\
\hline Q & 1973 & 20,300 \\
\hline Q & 1974 & 46,700 \\
\hline$Q$ & 1975 & 17,100 \\
\hline Q & 1976 & 2,200 \\
\hline Q & 1977 & 478 \\
\hline Q & 1978 & 41,500 \\
\hline Q & 1979 & 9,650 \\
\hline Q & 1980 & 36,000 \\
\hline Q & 1981 & 15,500 \\
\hline Q & 1982 & 22,600 \\
\hline Q & 1983 & 53,100 \\
\hline Q & 1984 & 30,700 \\
\hline Q & 1985 & 6,290 \\
\hline Q & 1986 & 65,200 \\
\hline Q & 1987 & 4,880 \\
\hline Q & 1988 & 15,400 \\
\hline Q & 1989 & 6,680 \\
\hline Q & 1990 & 3,000 \\
\hline Q & 1991 & 11,200 \\
\hline Q & 1992 & 11,400 \\
\hline Q & 1993 & 36,800 \\
\hline$Q$ & 1994 & 4,540 \\
\hline$Q$ & 1995 & 81,700 \\
\hline Q & 1996 & 16,200 \\
\hline 0 & 1997 & 51,400 \\
\hline & 1998 & 52,500 \\
\hline
\end{tabular}


Table A4. Estimated, unregulated annual peak discharge for key dam sites in the SacramentoSan Joaquin River Basin, California.-Continued

[For some stations, missing discharges are represented by interval discharge thresholds. These sites have a row of data after the STATION row with THRESHOLD indicated. The next two numbers in the THRESHOLD row show the first and last year of missing record. The next number represents a large discharge threshold that presumably was not reached during the missing years. The INF following the threshold discharge simply indicates the largest possible discharge during the missing years (infinitely large). The first column after the STATION and THRESHOLD rows indicates whether discharge is a single-valued discharge (Q) or an interval discharge (QINT). Second column is the water year for each discharge. For each single-valued discharge, the third column is the discharge in cubic feet per second, and for each interval discharge, the third and fourth columns represent the range in discharge in cubic feet per second. For each single-valued discharge, a value of 1 in the last column indicates that the discharge is a recorded, unregulated, discharge. A value of 2 in the last column indicates that the discharge was a recorded, regulated discharge]

Station - 11407099 Feather River at Oroville, California (simulated unregulated peaks)

\begin{tabular}{|c|c|c|c|}
\hline Threshold & 1998-2006 & $391,000-$ INF & \\
\hline Q & 1902 & 41,000 & 1 \\
\hline Q & 1903 & 102,000 & 1 \\
\hline Q & 1904 & 118,000 & 1 \\
\hline Q & 1905 & 81,000 & 1 \\
\hline Q & 1906 & 128,000 & 1 \\
\hline Q & 1907 & 230,000 & 1 \\
\hline Q & 1908 & 16,300 & 1 \\
\hline Q & 1909 & 140,000 & 1 \\
\hline Q & 1910 & 31,000 & 1 \\
\hline Q & 1911 & 84,500 & \\
\hline Q & 1912 & 16,300 & \\
\hline Q & 1913 & 14,000 & \\
\hline Q & 1914 & 99,900 & \\
\hline Q & 1915 & 76,900 & \\
\hline Q & 1916 & 46,300 & \\
\hline Q & 1917 & 81,700 & \\
\hline Q & 1918 & 29,700 & \\
\hline Q & 1919 & 50,000 & \\
\hline Q & 1920 & 21,700 & \\
\hline Q & 1921 & 56,400 & \\
\hline Q & 1922 & 37,100 & \\
\hline Q & 1923 & 21,200 & \\
\hline Q & 1924 & 34,500 & \\
\hline Q & 1925 & 55,600 & \\
\hline Q & 1926 & 50,400 & \\
\hline Q & 1927 & 92,800 & \\
\hline Q & 1928 & 146,000 & \\
\hline Q & 1929 & 11,700 & \\
\hline Q & 1930 & 8,7300 & \\
\hline Q & 1931 & 9,310 & \\
\hline Q & 1932 & 18,700 & \\
\hline Q & 1933 & 8,800 & \\
\hline Q & 1934 & 17,000 & \\
\hline Q & 1935 & 58,200 & \\
\hline Q & 1936 & 62,600 & \\
\hline Q & 1937 & 19,600 & \\
\hline Q & 1938 & 189,000 & \\
\hline
\end{tabular}


Table A4. Estimated, unregulated annual peak discharge for key dam sites in the SacramentoSan Joaquin River Basin, California.-Continued

[For some stations, missing discharges are represented by interval discharge thresholds. These sites have a row of data after the STATION row with THRESHOLD indicated. The next two numbers in the THRESHOLD row show the first and last year of missing record. The next number represents a large discharge threshold that presumably was not reached during the missing years. The INF following the threshold discharge simply indicates the largest possible discharge during the missing years (infinitely large). The first column after the STATION and THRESHOLD rows indicates whether discharge is a single-valued discharge (Q) or an interval discharge (QINT). Second column is the water year for each discharge. For each single-valued discharge, the third column is the discharge in cubic feet per second, and for each interval discharge, the third and fourth columns represent the range in discharge in cubic feet per second. For each single-valued discharge, a value of 1 in the last column indicates that the discharge is a recorded, unregulated, discharge. A value of 2 in the last column indicates that the discharge was a recorded, regulated discharge]

Station - 11407099 Feather River at Oroville, California (simulated unregulated peaks) —Cont.

\begin{tabular}{|c|c|c|}
\hline $\mathrm{Q}$ & 1939 & 7,860 \\
\hline $\mathrm{Q}$ & 1940 & 158,000 \\
\hline $\mathrm{Q}$ & 1941 & 82,000 \\
\hline $\mathrm{Q}$ & 1942 & 101,000 \\
\hline $\mathrm{Q}$ & 1943 & 72,100 \\
\hline $\mathrm{Q}$ & 1944 & 18,900 \\
\hline $\mathrm{Q}$ & 1945 & 51,500 \\
\hline Q & 1946 & 50,100 \\
\hline $\mathrm{Q}$ & 1947 & 33,900 \\
\hline $\mathrm{Q}$ & 1948 & 35,100 \\
\hline $\mathrm{Q}$ & 1949 & 14,000 \\
\hline $\mathrm{Q}$ & 1950 & 43,200 \\
\hline $\mathrm{Q}$ & 1951 & 77,900 \\
\hline Q & 1952 & 51,000 \\
\hline $\mathrm{Q}$ & 1953 & 113,000 \\
\hline $\mathrm{Q}$ & 1954 & 52,100 \\
\hline $\mathrm{Q}$ & 1955 & 11,500 \\
\hline $\mathrm{Q}$ & 1956 & 218,000 \\
\hline $\mathrm{Q}$ & 1957 & 69,800 \\
\hline Q & 1958 & 86,000 \\
\hline $\mathrm{Q}$ & 1959 & 29,900 \\
\hline $\mathrm{Q}$ & 1960 & 113,000 \\
\hline $\mathrm{Q}$ & 1961 & 15,600 \\
\hline $\mathrm{Q}$ & 1962 & 38,100 \\
\hline Q & 1963 & 160,000 \\
\hline $\mathrm{Q}$ & 1964 & 20,700 \\
\hline $\mathrm{Q}$ & 1965 & 214,000 \\
\hline Q & 1966 & 17,000 \\
\hline $\mathrm{Q}$ & 1967 & 59,300 \\
\hline Q & 1968 & 42,900 \\
\hline $\mathrm{Q}$ & 1969 & 161,000 \\
\hline $\mathrm{Q}$ & 1970 & 136,000 \\
\hline $\mathrm{Q}$ & 1971 & 71,300 \\
\hline Q & 1972 & 20,200 \\
\hline Q & 1973 & 52,300 \\
\hline Q & 1974 & 125,000 \\
\hline Q & 1975 & 33,500 \\
\hline
\end{tabular}


Table A4. Estimated, unregulated annual peak discharge for key dam sites in the SacramentoSan Joaquin River Basin, California.-Continued

[For some stations, missing discharges are represented by interval discharge thresholds. These sites have a row of data after the STATION row with THRESHOLD indicated. The next two numbers in the THRESHOLD row show the first and last year of missing record. The next number represents a large discharge threshold that presumably was not reached during the missing years. The INF following the threshold discharge simply indicates the largest possible discharge during the missing years (infinitely large). The first column after the STATION and THRESHOLD rows indicates whether discharge is a single-valued discharge (Q) or an interval discharge (QINT) Second column is the water year for each discharge. For each single-valued discharge, the third column is the discharge in cubic feet per second, and for each interval discharge, the third and fourth columns represent the range in discharge in cubic feet per second. For each single-valued discharge, a value of 1 in the last column indicates that the discharge is a recorded, unregulated, discharge. A value of 2 in the last column indicates that the discharge was a recorded, regulated discharge]

Station - 11407099 Feather River at Oroville, California (simulated unregulated peaks) —Cont.

\begin{tabular}{|c|c|c|c|}
\hline Q & 1976 & 11,800 & \\
\hline Q & 1977 & 3,850 & \\
\hline Q & 1978 & 60,100 & \\
\hline Q & 1979 & 24,000 & \\
\hline Q & 1980 & 162,000 & \\
\hline Q & 1981 & 19,000 & \\
\hline Q & 1982 & 113,000 & \\
\hline Q & 1983 & 113,000 & \\
\hline Q & 1984 & 83,700 & \\
\hline Q & 1985 & 17,600 & \\
\hline Q & 1986 & 264,000 & \\
\hline Q & 1987 & 32,400 & \\
\hline Q & 1988 & 18,900 & \\
\hline Q & 1989 & 98,200 & \\
\hline Q & 1990 & 14,600 & \\
\hline Q & 1991 & 54,000 & \\
\hline Q & 1992 & 24,900 & \\
\hline Q & 1993 & 64,900 & \\
\hline Q & 1994 & 9,030 & \\
\hline Q & 1995 & 157,000 & \\
\hline Q & 1996 & 63,500 & \\
\hline Q & 1997 & 391,000 & \\
\hline \multicolumn{4}{|c|}{$\begin{array}{l}\text { Station - } 11413599 \text { North Yuba River below Bullards Bar Dam, California (simulated unregulatec } \\
\text { peaks) }\end{array}$} \\
\hline Threshold & 1939-1940 & 160,000 -INF & \\
\hline Threshold & 1967-1969 & 160,000-INF & \\
\hline Threshold & 1998-2006 & 160,000-INF & \\
\hline Q & 1938 & 69,800 & 1 \\
\hline Q & 1941 & 30,600 & 1 \\
\hline Q & 1942 & 28,100 & 1 \\
\hline Q & 1943 & 44,200 & 1 \\
\hline Q & 1944 & 5,110 & 1 \\
\hline Q & 1945 & 26,400 & 1 \\
\hline Q & 1946 & 20,000 & 1 \\
\hline Q & 1947 & 18,600 & 1 \\
\hline Q & 1948 & 15,200 & 1 \\
\hline Q & 1949 & 5,060 & 1 \\
\hline Q & 1950 & 13,300 & 1 \\
\hline
\end{tabular}


Table A4. Estimated, unregulated annual peak discharge for key dam sites in the SacramentoSan Joaquin River Basin, California.-Continued

[For some stations, missing discharges are represented by interval discharge thresholds. These sites have a row of data after the STATION row with THRESHOLD indicated. The next two numbers in the THRESHOLD row show the first and last year of missing record. The next number represents a large discharge threshold that presumably was not reached during the missing years. The INF following the threshold discharge simply indicates the largest possible discharge during the missing years (infinitely large). The first column after the STATION and THRESHOLD rows indicates whether discharge is a single-valued discharge (Q) or an interval discharge (QINT). Second column is the water year for each discharge. For each single-valued discharge, the third column is the discharge in cubic feet per second, and for each interval discharge, the third and fourth columns represent the range in discharge in cubic feet per second. For each single-valued discharge, a value of 1 in the last column indicates that the discharge is a recorded, unregulated, discharge. A value of 2 in the last column indicates that the discharge was a recorded, regulated discharge]

Station - 11413599 North Yuba River below Bullards Bar Dam, California (simulated unregulated peaks)-Continued

\begin{tabular}{|c|c|c|c|}
\hline Q & 1951 & 47,100 & 1 \\
\hline Q & 1952 & 23,200 & 1 \\
\hline Q & 1953 & 34,000 & 1 \\
\hline Q & 1954 & 31,600 & 1 \\
\hline Q & 1955 & 5,160 & 1 \\
\hline Q & 1956 & 70,000 & 1 \\
\hline Q & 1957 & 30,200 & 1 \\
\hline Q & 1958 & 34,600 & 1 \\
\hline Q & 1959 & 10,100 & 1 \\
\hline Q & 1960 & 43,600 & 1 \\
\hline Q & 1961 & 3,540 & 1 \\
\hline Q & 1962 & 21,000 & 1 \\
\hline Q & 1963 & 83,000 & 1 \\
\hline Q & 1964 & 10,400 & 1 \\
\hline Q & 1965 & 91,600 & 1 \\
\hline Q & 1966 & 4,420 & 1 \\
\hline Q & 1970 & 6,4600 & \\
\hline Q & 1971 & 22,000 & \\
\hline Q & 1972 & 10,600 & \\
\hline Q & 1973 & 20,500 & \\
\hline Q & 1974 & 39,900 & \\
\hline Q & 1975 & 16,300 & \\
\hline Q & 1976 & 4,750 & \\
\hline Q & 1977 & 1,370 & \\
\hline Q & 1978 & 19,900 & \\
\hline Q & 1979 & 9,810 & \\
\hline Q & 1980 & 94,300 & \\
\hline Q & 1981 & 8,780 & \\
\hline Q & 1982 & 66,500 & \\
\hline Q & 1983 & 47,900 & \\
\hline Q & 1984 & 38,700 & \\
\hline Q & 1985 & 8,040 & \\
\hline Q & 1986 & 123,000 & \\
\hline Q & 1987 & 17,200 & \\
\hline Q & 1988 & 5,790 & \\
\hline
\end{tabular}


Table A4. Estimated, unregulated annual peak discharge for key dam sites in the SacramentoSan Joaquin River Basin, California.-Continued

[For some stations, missing discharges are represented by interval discharge thresholds. These sites have a row of data after the STATION row with THRESHOLD indicated. The next two numbers in the THRESHOLD row show the first and last year of missing record. The next number represents a large discharge threshold that presumably was not reached during the missing years. The INF following the threshold discharge simply indicates the largest possible discharge during the missing years (infinitely large). The first column after the STATION and THRESHOLD rows indicates whether discharge is a single-valued discharge (Q) or an interval discharge (QINT). Second column is the water year for each discharge. For each single-valued discharge, the third column is the discharge in cubic feet per second, and for each interval discharge, the third and fourth columns represent the range in discharge in cubic feet per second. For each single-valued discharge, a value of 1 in the last column indicates that the discharge is a recorded, unregulated, discharge. A value of 2 in the last column indicates that the discharge was a recorded, regulated discharge]

Station - 11413599 North Yuba River below Bullards Bar Dam, California (simulated unregulated peaks)-Continued

\begin{tabular}{|c|c|c|c|}
\hline $\mathrm{Q}$ & 1989 & 36,500 & \\
\hline Q & 1990 & 8,140 & \\
\hline Q & 1991 & 33,500 & \\
\hline Q & 1992 & 13,300 & \\
\hline Q & 1993 & 21,000 & \\
\hline Q & 1994 & 3,100 & \\
\hline Q & 1995 & 47,100 & \\
\hline Q & 1996 & 33,700 & \\
\hline Q & 1997 & 160,000 & \\
\hline \multicolumn{4}{|c|}{ Station - 11446599 American River at Fair Oaks, California (simulated unregulated peaks) } \\
\hline Threshold & 1848-1861 & 300,000-INF & \\
\hline Threshold & 1863-1904 & $300,000-I N F$ & \\
\hline Threshold & 1999-2006 & $300,000-I N F$ & \\
\hline QINT & 1862 & $300,000-336,000$ & \\
\hline Q & 1905 & 24,200 & 1 \\
\hline Q & 1906 & 59,700 & 1 \\
\hline Q & 1907 & 156,000 & 1 \\
\hline Q & 1908 & 10,300 & 1 \\
\hline Q & 1909 & 119,000 & 1 \\
\hline Q & 1910 & 47,000 & 1 \\
\hline Q & 1911 & 81,300 & 1 \\
\hline Q & 1912 & 12,100 & 1 \\
\hline Q & 1913 & 12,700 & 1 \\
\hline Q & 1914 & 74,100 & 1 \\
\hline Q & 1915 & 47,900 & 1 \\
\hline Q & 1916 & 40,700 & 1 \\
\hline Q & 1917 & 42,300 & 1 \\
\hline Q & 1918 & 15,800 & \\
\hline Q & 1919 & 67,500 & 1 \\
\hline Q & 1920 & 20,100 & 1 \\
\hline Q & 1921 & 39,200 & 1 \\
\hline Q & 1922 & 31,600 & 1 \\
\hline Q & 1923 & 39,000 & 1 \\
\hline Q & 1924 & 14,000 & 1 \\
\hline Q & 1925 & 99,500 & 1 \\
\hline Q & 1926 & 27,400 & 1 \\
\hline
\end{tabular}


Table A4. Estimated, unregulated annual peak discharge for key dam sites in the SacramentoSan Joaquin River Basin, California.-Continued

[For some stations, missing discharges are represented by interval discharge thresholds. These sites have a row of data after the STATION row with THRESHOLD indicated. The next two numbers in the THRESHOLD row show the first and last year of missing record. The next number represents a large discharge threshold that presumably was not reached during the missing years. The INF following the threshold discharge simply indicates the largest possible discharge during the missing years (infinitely large). The first column after the STATION and THRESHOLD rows indicates whether discharge is a single-valued discharge $(\mathrm{Q})$ or an interval discharge (QINT). Second column is the water year for each discharge. For each single-valued discharge, the third column is the discharge in cubic feet per second, and for each interval discharge, the third and fourth columns represent the range in discharge in cubic feet per second. For each single-valued discharge, a value of 1 in the last column indicates that the discharge is a recorded, unregulated, discharge. A value of 2 in the last column indicates that the discharge was a recorded, regulated discharge]

Station - 11446599 American River at Fair Oaks, California (simulated unregulated peaks)—Cont.

\begin{tabular}{|c|c|c|c|}
\hline Q & 1927 & 67,700 & 1 \\
\hline Q & 1928 & 163,000 & 1 \\
\hline Q & 1929 & 26,000 & 1 \\
\hline Q & 1930 & 24,400 & 1 \\
\hline Q & 1931 & 9,900 & 1 \\
\hline Q & 1932 & 21,100 & 1 \\
\hline Q & 1933 & 16,500 & 1 \\
\hline Q & 1934 & 22,600 & 1 \\
\hline Q & 1935 & 60,900 & 1 \\
\hline Q & 1936 & 58,300 & 1 \\
\hline Q & 1937 & 33,000 & 1 \\
\hline Q & 1938 & 114,000 & 1 \\
\hline Q & 1939 & 10,900 & 1 \\
\hline Q & 1940 & 89,200 & 1 \\
\hline Q & 1941 & 38,800 & 1 \\
\hline Q & 1942 & 83,200 & 1 \\
\hline Q & 1943 & 152,000 & 1 \\
\hline Q & 1944 & 20,100 & 1 \\
\hline Q & 1945 & 94,400 & 1 \\
\hline Q & 1946 & 42,200 & 1 \\
\hline Q & 1947 & 27,900 & 1 \\
\hline Q & 1948 & 21,000 & 1 \\
\hline Q & 1949 & 37,500 & 1 \\
\hline Q & 1950 & 34,400 & 1 \\
\hline Q & 1951 & 180,000 & 1 \\
\hline Q & 1952 & 37,200 & 1 \\
\hline Q & 1953 & 49,700 & 1 \\
\hline Q & 1954 & 42,600 & 1 \\
\hline Q & 1955 & 13,300 & \\
\hline Q & 1956 & 273,000 & \\
\hline Q & 1957 & 49,500 & \\
\hline Q & 1958 & 57,000 & \\
\hline Q & 1959 & 19,800 & \\
\hline Q & 1960 & 86,500 & \\
\hline Q & 1961 & 8,590 & \\
\hline Q & 1962 & 47,100 & \\
\hline Q & 1963 & 218,000 & \\
\hline
\end{tabular}


Table A4. Estimated, unregulated annual peak discharge for key dam sites in the SacramentoSan Joaquin River Basin, California.-Continued

[For some stations, missing discharges are represented by interval discharge thresholds. These sites have a row of data after the STATION row with THRESHOLD indicated. The next two numbers in the THRESHOLD row show the first and last year of missing record. The next number represents a large discharge threshold that presumably was not reached during the missing years. The INF following the threshold discharge simply indicates the largest possible discharge during the missing years (infinitely large). The first column after the STATION and THRESHOLD rows indicates whether discharge is a single-valued discharge (Q) or an interval discharge (QINT). Second column is the water year for each discharge. For each single-valued discharge, the third column is the discharge in cubic feet per second, and for each interval discharge, the third and fourth columns represent the range in discharge in cubic feet per second. For each single-valued discharge, a value of 1 in the last column indicates that the discharge is a recorded, unregulated, discharge. A value of 2 in the last column indicates that the discharge was a recorded, regulated discharge]

Station - 11446599 American River at Fair Oaks, California (simulated unregulated peaks)—Cont.

\begin{tabular}{|c|c|c|}
\hline Q & 1964 & 22,000 \\
\hline Q & 1965 & 264,000 \\
\hline Q & 1966 & 10,900 \\
\hline Q & 1967 & 48,500 \\
\hline Q & 1968 & 32,500 \\
\hline Q & 1969 & 116,000 \\
\hline Q & 1970 & 123,000 \\
\hline Q & 1971 & 45,500 \\
\hline Q & 1972 & 127,00 \\
\hline Q & 1973 & 66,900 \\
\hline Q & 1974 & 54,700 \\
\hline Q & 1975 & 39,900 \\
\hline Q & 1976 & 132,00 \\
\hline Q & 1977 & 27,90 \\
\hline Q & 1978 & 41,500 \\
\hline Q & 1979 & 23,800 \\
\hline Q & 1980 & 177,000 \\
\hline Q & 1981 & 20,000 \\
\hline Q & 1982 & 159,000 \\
\hline Q & 1983 & 94,800 \\
\hline Q & 1984 & 89,600 \\
\hline Q & 1985 & 17,300 \\
\hline Q & 1986 & 246,000 \\
\hline Q & 1987 & 14,900 \\
\hline Q & 1988 & 6,700 \\
\hline Q & 1989 & 45,300 \\
\hline Q & 1990 & 9,490 \\
\hline Q & 1991 & 36,200 \\
\hline Q & 1992 & 17,000 \\
\hline Q & 1993 & 45,700 \\
\hline Q & 1994 & 6,140 \\
\hline Q & 1995 & 94,100 \\
\hline Q & 1996 & 74,100 \\
\hline Q & 1997 & 369,000 \\
\hline Q & 1998 & 56,400 \\
\hline
\end{tabular}


This page intentionally left blank. 


\section{Appendix B. Extended Bayesian GLS Regional Skew Analysis for California}

The U.S. Geological Survey (USGS) Southeastern United States regional skew study shows how a Bayesian generalized least squares (B-GLS) analysis typically is conducted (Feaster and others, 2009; and Gotvald and others, 2009; Veilleux, 2009; Weaver and others, 2009). The cross correlations between annual-peak discharges in California were considerably larger than those in the Southeastern United States study (fig. 4). When a B-GLS analysis was attempted on the California data set, results were not consistent because of the high cross correlations. A Bayesian GLS analysis seeks to exploit the cross correlations among the sample skews to obtain the best possible estimates of model parameters. If the cross correlations are large, the GLS estimators can become more complicated as a result of the effort to find the most efficient estimator of the parameters. The accuracy of the model (eq. 9) used to calculate the cross correlations of concurrent annual-peak discharges in California was equivalent to 52 years of actual at-site data. While this model describes the overall structure of the California data set, the calculated cross correlation between any two sites is not precise enough to justify the sophisticated weights (both positive and negative) that the Bayesian GLS analysis generates. Thus, an alternative procedure was developed so that the regional skew analysis would provide reliable results.

To this end, a weighted least squares (WLS) analysis that does not use cross correlations was first used to develop estimators of the regression coefficients for each regional skew model. After the regression model coefficients were determined using WLS, the precision of the model and the precision of the regression coefficients were estimated using a modified GLS analysis. However, because of the extensive use of low-outlier censoring and historical information in the expected moments algorithm (EMA) analysis used in California, the simple formulas provided in Bulletin 17B and by Griffis and Stedinger (2009) do not reliably represent the variance of the sample skewness estimators. Thus, a Monte Carlo study was done to determine the actual sample variance of the skewness coefficient when a low outlier test is employed to identify samples for special treatment. Finally, a modified Bayesian GLS analysis using only data from pristine sites (that is, sites without low outliers, zero flows, reconstructed records at key dam sites, or historical information) provided the estimate of the model error variance (the precision of the model) and the precision of the estimated model parameters.
The specific computational steps used in the California regional skew analysis are described below.

1. A WLS analysis was used to derive the regression model parameter estimates using the complete set of records. The resultant model yielded an unbiased regional estimator of the skew at any site. The WLS analysis explicitly reflects variations in record length, but as previously described, does not consider cross correlations among the skewness estimators.

The WLS analysis was done in two steps using unbiased at-site sample skewness estimators and variances of at-site unbiased skewness estimators when possible. A correction factor developed by Tasker and Stedinger (1986) and applied by Reis and others (2005) was used to unbias the at-site skews and the estimates of their variance. Equations to derive the unbiased at-site skews and their variances are given below.

$$
\hat{\gamma}_{i}=\left[1+\frac{6}{N_{i}}\right] G_{i}
$$

and

$$
\operatorname{Var}\left[\hat{\gamma}_{\mathrm{i}}\right]=\left[1+\frac{6}{\mathrm{~N}_{\mathrm{i}}}\right]^{2} \operatorname{Var}\left[\mathrm{G}_{\mathrm{i}}\right],
$$

where

$$
\begin{aligned}
& \hat{\gamma}_{i} \text { is the unbiased at-site skew for site } i, \\
& G_{i} \text { is the traditiional biased at-site skew estimator } \\
& \quad \text { for site } i \text {, and } \\
& N_{i} \text { is the systematic record length at site } i .
\end{aligned}
$$

When unbiasing the skew, only the number of systematic peaks was considered. Thus, any historical flood periods in the EMA analysis were not included in the calculation of the correction factors. 
In the first step of the WLS analysis, BayesianWeighted Least Squares (B-WLS) was used to estimate the model error variance, denoted $\sigma_{\delta \text {,B-WLS }}^{2}$. Then, $\sigma_{\delta, \text { B-WLS }}^{2}$ was used in a method-of-moments WLS (MM-WLS) analysis to generate the weights, $\mathbf{W}$, needed to estimate the regression parameters $\hat{\boldsymbol{\beta}}$. In order to compute the MM-WLS weights, a diagonal covariance matrix, $\Lambda_{\mathrm{WLS}}\left(\sigma_{\delta \text {, B-WLS }}^{2}\right)$, was created. The diagonal elements of the covariance matrix are the sums of the estimated error variance, $\sigma_{\delta, \text { B-WLS }}^{2}$, and the variance of the unbiased at-site skew, $\operatorname{Var}\left[\hat{\gamma}_{i}\right]$, which depends only on the at-site annual peak flow record length, and the estimated skew for that site. The at-site skew, $G_{i}$, and the variance of the at-site skew estimator, $\operatorname{Var}\left[G_{i}\right]$, were calculated from the entire flow record, including historical and systematic peaks, using the EMA method (Cohn and others, 1997). These biased estimates of the skew and the variance of the skew produced by EMA were then unbiased using equations B1 and B2, respectively, which gave estimates of the unbiased at-site skew, $\hat{\gamma}_{i}$ and the at-site skew variance $\operatorname{Var}\left[\hat{\gamma}_{\mathrm{i}}\right]$. The off-diagonal elements of $\Lambda_{\mathrm{WLS}}\left(\sigma_{\delta, \mathrm{B} \text {-WLS }}^{2}\right)$ were zero, because cross correlations between gage sites were not considered in the WLS analysis. Thus, the $(n \times n)$ covariance matrix, $\Lambda_{\mathrm{WLS}}\left(\sigma_{\delta, \mathrm{B}-\mathrm{WLS}}^{2}\right)$, was

$$
\Lambda_{\mathrm{WLS}}\left(\sigma_{\delta, \mathrm{B}-\mathrm{WLS}}^{2}\right)=\sigma_{\delta, \mathrm{B}-\mathrm{WLS}}^{2} \mathbf{I}+\operatorname{diag}(\operatorname{Var}[\hat{\gamma}])
$$

where

$\mathbf{I}$ is an $(\mathrm{n} \times \mathrm{n})$ identity matrix, $\mathrm{n}$ is the number of gage sites in the study, and $\operatorname{diag}(\operatorname{Var}[\hat{\gamma}])$ is an $(n \times n)$ matrix containing the variances of the unbiased at-site sample skewness estimators, $\operatorname{Var}[\hat{\gamma}]$, on the diagonal and zeros on the off-diagonal.

Using that covariance matrix, the MM-WLS weights are calculated as

$$
\mathbf{W}=\left[\mathbf{X}^{\top} \Lambda^{-1}{ }_{\mathrm{WLS}}\left(\sigma_{\delta, \mathrm{B}-\mathrm{WLS}}^{2}\right) \mathbf{X}\right]^{-1} \mathbf{X}^{\top} \boldsymbol{\Lambda}^{-1}{ }_{\mathrm{WLS}}\left(\sigma_{\delta, \mathrm{B}-\mathrm{WLS}}^{2}\right),
$$

where

$\mathbf{W}$ is $(k \times n)$ matrix of weights,

$\mathbf{X}$ is an $(n \times k)$ matrix of basin parameters, and

$\mathrm{k}$ is the number of basin characteristics.
These weights were used to compute the final estimates of the regression parameters $\hat{\boldsymbol{\beta}}$ as

$$
\hat{\boldsymbol{\beta}}=\mathbf{W} \hat{\gamma}
$$

where

$$
\begin{aligned}
& \hat{\beta} \text { is an }(k \times 1) \text { vector of regression parameters, } \\
& \text { and } \\
& \hat{\gamma} \text { is an }(n \times 1) \text { vector of unbiased at-site sample } \\
& \text { skewness estimators. }
\end{aligned}
$$

Both the B-WLS and the MM-WLS analyses include sites that had historical information, zero flows, and low outliers.

2. After estimating the regression parameters, the true model error variance needs to be estimated. However, the extensive censoring of low outliers, the occurrence of zero flows, and the addition of regional historical flood information for some sites in the data set complicated the estimation of the model error variance. Thus, to estimate the true model error variance, a simpler, "pristine" data set was developed. The pristine data set is a subset of the larger data set used in the WLS estimation of the regression parameters, and it does not include sites that had zero flows, low outliers as determined by EMA, or any reconstructed flow records. Any historical flood information was ignored.

Because the pristine data set excluded sites with low outliers, the formulas provided in Bulletin 17B and by Griffis and Stedinger (2009) misrepresented the variance of the sample skewness estimators. Thus, a new Monte Carlo study was done to determine the actual variance of the skewness coefficient when a low outlier test is used to exclude some data. The Monte Carlo analysis of sample skews from an LP3 distribution used only complete samples with no low outliers. Results from the Monte Carlo analysis were used to determine the bias associated with the sample skewness coefficient $\mathbf{G}$ when samples with low outliers were dropped from the analysis. Two functions were computed: the mean of the sample skew, denoted $m(\gamma, \mathbf{N})$, and its variance, denoted $v(\gamma, \mathbf{N})$,

$$
\mathrm{m}(\boldsymbol{\gamma}, \mathbf{N})=\mathrm{E}_{\left\{\mathrm{x}_{\mathrm{i}} \mid \mathrm{no}-\text { outliers }\right\}}[\mathbf{G} \mid \boldsymbol{\gamma}, \mathbf{N}],
$$

and

$$
\mathrm{V}(\boldsymbol{\gamma}, \mathbf{N})=\operatorname{Var}_{\left\{\mathrm{x}_{i} \mid \text { no-outliers }\right\}}[\mathbf{G} \mid \gamma, \mathbf{N}]
$$


These expectations were computed using only those LP3 samples, $\left\{\mathrm{x}_{\mathrm{i}}\right\}$, that did not contain low outliers, as determined by a 10 percent Grubbs-Beck test recommended by Bulletin 17B. Figure B1 summarizes the Monte Carlo results for 1,000 simulations of $\mathrm{N}=50$ years of at-site annual-peak discharges. The $x$-axis represents the population (true) skew, $\gamma$, and the $y$-axis represents both the mean of the estimated skew $m(\gamma, \mathbf{N})$ and the standard deviation of the estimated skew [the square root of the variance $v(\gamma, \mathbf{N})$ ] for LP3 samples that had no low outliers. Figure B1 shows that when only samples without low outliers are considered, the mean of the estimated skews (the dashed line) can be significantly biased. Samples with low outliers are very likely to be negatively skewed, so analyzing data using an unbiased estimator and omitting samples with low outliers is expected to yield a regional skewness estimator that is positively biased if the bias is not corrected. When the true skew is highly positive, the bias is small and slightly negative, as few samples are omitted because of low outliers. When the true skew is highly negative, the standard deviation of the sample is greatly reduced, as shown by the dotted line in figure B1.

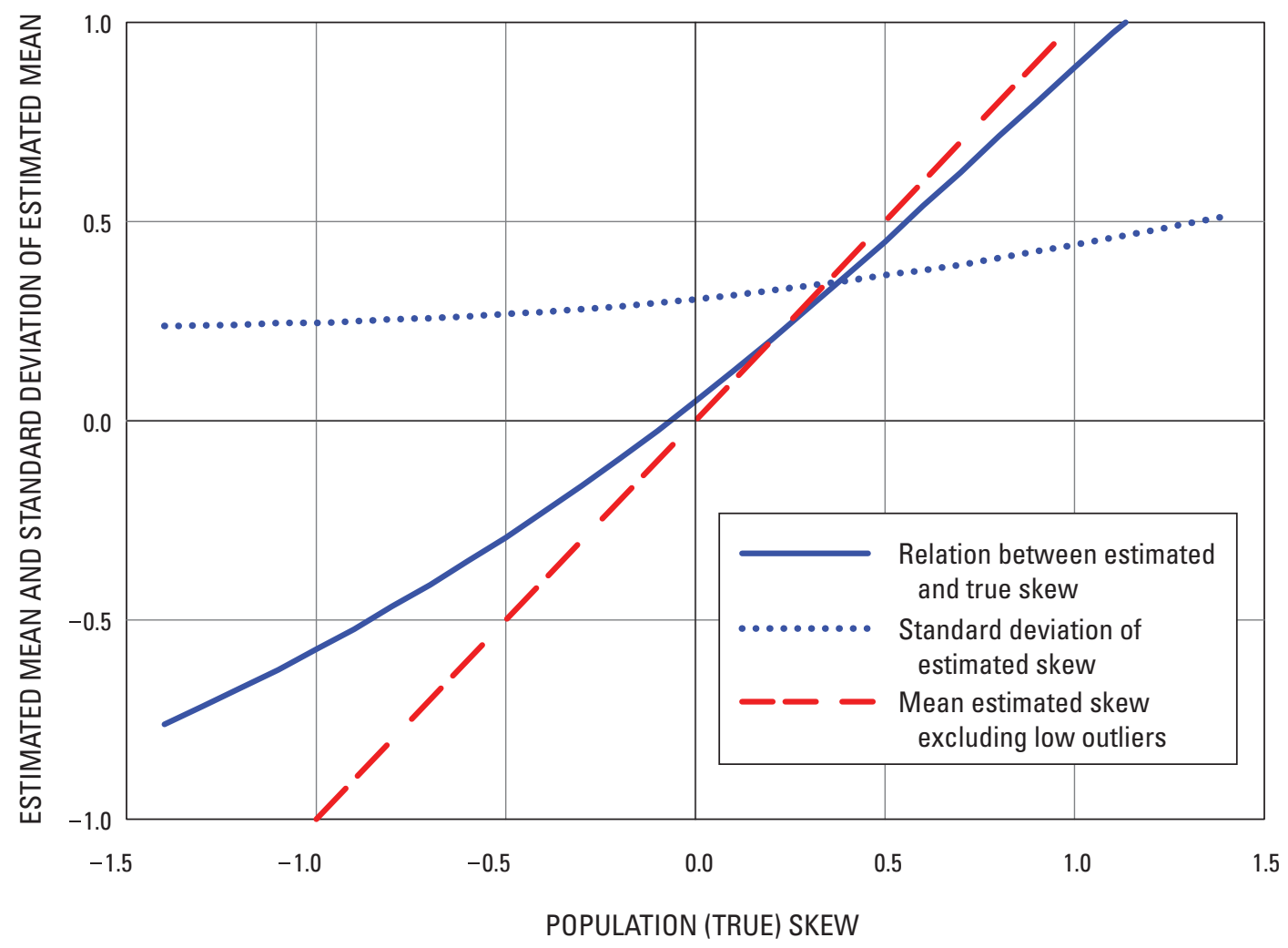

Figure B1. Relation between estimated skew and population (true) skew based on 1,000 Monte Carlo simulations of 50-year samples in California. The dashed line represents the mean, $m(\gamma, \mathbf{N})$, of the estimated skew across samples without outliers, and the dotted line represents the standard deviation [the square root of the variance, $v(\gamma, \mathbf{N})$ ] of that estimated skew across LP3 samples that do not contain low outliers. 
Skew was more negative when the dataset had more samples with low outliers (table B1). For example, 32 percent of the samples with a true at-site skew of -0.5 had low outliers and were therefore dropped, but only 10 percent of the samples with a true at-site skew of 0.0 were dropped. On the other hand, when the true at-site skew was highly positive, few samples were rejected, resulting in very little impact on the sampling distribution of the estimated skew. In the Monte Carlo simulation, when the at-site record length was 50 years and the skew was 0.3 , only 2 percent of the samples were rejected. When the skew was 0.5 or greater, none of the 50,000 samples generated contained low outliers (table B1).

The pattern evident in table B1 shows why the standard deviation of the estimated skew in samples without outliers increases as the true skew increases.

Table B1. Monte Carlo results showing the percent of samples, for different at-site skew values, dropped from the simulation due to the presence of low outliers

\begin{tabular}{|r|c|c|c|c|c|c|c|c|c|c|c|}
\hline Skew: & -1.5 & -1.0 & -0.8 & -0.5 & -0.3 & 0.0 & 0.3 & 0.5 & 0.8 & 1.0 & 1.5 \\
\hline \% of Samples Dropped: & $71 \%$ & $56 \%$ & $47 \%$ & $32 \%$ & $22 \%$ & $10 \%$ & $2 \%$ & $0 \%$ & $0 \%$ & $0 \%$ & $0 \%$ \\
\hline
\end{tabular}

3. The Monte Carlo experiments provided the expected value and variance of the sample skewness estimator based on samples without outliers. These values can be used with the pristine data set in the computations of the model error variance using B-GLS. By using the relationship for regional skew generated by the WLS analysis, the WLS mean regional skew estimate, $m_{R}(i)$, can be calculated for each site $i$ in the pristine data set as

$$
\mathbf{m}_{\mathrm{R}}=\mathbf{X} \hat{\boldsymbol{\beta}},
$$

where

$\mathbf{m}_{R}$ is an $\left(n_{p} \times 1\right)$ vector of WLS regional skew estimates for each site in the pristine data set,

$\mathbf{X}$ is an $\left(n_{p} \times k\right)$ matrix of basin parameters, $\hat{\boldsymbol{\beta}}$ is an $(k \times 1)$ vector of WLS regression parameters,

$n_{p}$ is the number of gage sites in the pristine data set, and

$\mathrm{k}$ is the number of basin characteristics.
4. The last step (4) is to estimate the model error variance using the pristine data set. If the model error variance, $\sigma_{\delta \text {, B-GLS }}^{2}$ were zero, then all of the observed variability would be sampling error, and we would have

$$
E\left[\left\{G_{i}-m\left(\gamma_{i}, N_{i}\right)\right\}^{2}\right]=v\left(\gamma_{i}, N_{i}\right) .
$$

However, we anticipate that the model will not be perfect, and thus estimating the model error variance will be challenging. The derivative

$$
d\{m(\gamma, \mathbf{N})\} / d \boldsymbol{\gamma} \neq 1
$$

will be used to correct the GLS analysis. Let the derivative in $\mathrm{B} 10$ be replaced by $r$,

$$
r=d\{m(\gamma, \mathbf{N})\} / d \gamma,
$$

and let $\sigma_{\delta, B-G L S}^{2}$ be the model error variance. Then a firstorder approximation of the expected value of regional skew variability would be

$$
E\left[\left\{G_{i}-m\left(\gamma_{i}, N_{i}\right)\right\}^{2}\right]=r^{2} \sigma_{\delta, B-G L S}^{2}+v\left(\gamma_{i}, N_{i}\right) .
$$


Thus, the GLS covariance matrix for the pristine data set is

$$
\Lambda_{\mathrm{p}}\left(\sigma_{\delta, \mathrm{B}-\mathrm{GLS}}^{2}\right)=\mathrm{r}^{2} \sigma_{\delta, \mathrm{B}-\mathrm{GLS}}^{2} \mathbf{I}_{\mathrm{p}}+\sum(\mathbf{G})
$$

where

$$
\begin{aligned}
& \Lambda_{p}\left(\sigma_{\delta, B-G L S}^{2}\right) \text { is an }\left(n_{p} \times n_{p}\right) \text { GLS covariance } \\
& \text { matrix, } \\
& \mathbf{I}_{p} \text { is an }\left(n_{p} \times n_{p}\right) \text { identity matrix, and } \\
& \Sigma(\mathbf{G}) \text { is an }\left(n_{p} \times n_{p}\right) \text { matrix containing the } \\
& \text { sampling variances of the biased } \\
& \text { skewness estimators } \\
& V a r\left[G_{i}\right]=v\left(\gamma_{i}, N_{i}\right)^{2} \text { and the } \\
& \text { covariances of the skewness } \\
& \text { estimators } G_{i} \text { in the pristine data } \\
& \text { set. }
\end{aligned}
$$

The values of $\boldsymbol{\Sigma}(\mathbf{G})$ were determined by the the crosscorrelation of concurrent systematic annual peak flows (eq. 6) and the of factor (eq. 7). In calculating the of factor used to determine the ratio of the number of concurrent peak flows at a pair of sites to the total number of peak flows at both sites, only the systematic records were considered.

The covariance matrix for the skewness coefficients for the pristine data set, $\Lambda_{\mathrm{p}}\left(\sigma_{\delta, \mathrm{B}-\mathrm{GLS}}^{2}\right)$, and the conditional means of the sample skews, $m(\gamma, \mathbf{N})$ are used in a Bayesian framework to compute the posterior distribution of the model error variance, and in particular, the posterior mean of the true model error variance.

The B-GLS model error variance can then be used to compute the precision of the regression parameters, $\hat{\boldsymbol{\beta}}$, that were calculated with the WLS weights, $\mathbf{W}$, as $\hat{\boldsymbol{\beta}}=\mathbf{W} \hat{\boldsymbol{\gamma}}$. Using the posterior mean of the true model error variance in $\boldsymbol{\Lambda}$, the variance of $\hat{\boldsymbol{\beta}}$ is simply

$$
\operatorname{Var}[\hat{\boldsymbol{\beta}}]=\mathbf{W} \boldsymbol{\Lambda}\left(\sigma_{\delta, \mathrm{B}-\mathrm{GLS}}^{2}\right) \mathbf{W}^{\top}
$$

where $\Lambda\left(\sigma_{\delta \text {, B-GLS }}^{2}\right)$ is an $(n \times n)$ covariance matrix that uses all of the sites, not just those listed in the pristine data set, and $\left(\sigma_{\delta, \mathrm{B}-\mathrm{GLS}}^{2}\right)$ is the posterior mean of the model error variance calculated from the B-GLS analysis described above. It is important to note that $\Lambda\left(\sigma_{\delta \text {,B-GLS }}^{2}\right)$ is not the same as the covariance matrix $\Lambda_{\mathrm{WLS}}\left(\sigma_{\delta \text {, B-WLS }}^{2}\right)$ used in the MM-WLS analysis of all of the sites or the $\Lambda_{\mathrm{p}}\left(\sigma_{\delta, \mathrm{B}-\mathrm{GLS}}^{2}\right)$ used in the B-GLS analysis of just the pristine sites. Instead, $\Lambda\left(\sigma_{\delta, \mathrm{B}-\mathrm{GLS}}^{2}\right)$ is

$$
\Lambda\left(\sigma_{\delta, \mathrm{B}-\mathrm{GLS}}^{2}\right)=\sigma_{\delta, \mathrm{B}-\mathrm{GLS}}^{2} \mathbf{I}+\Sigma(\hat{\gamma})
$$

where

$$
\begin{aligned}
& \Lambda\left(\sigma_{\delta, \text { B-GLS }}^{2}\right) \text { is an }(n \times n) \text { GLS covariance matrix, } \\
& \mathbf{I} \text { is an }(n \times n) \text { identity matrix, } \\
& \Sigma(\hat{\gamma}) \text { is an }(n \times n) \text { matrix containing the } \\
& \text { sampling variances of the unbiased } \\
& \text { skewness estimators } \operatorname{Var}\left[\hat{\gamma}_{i}\right] \text { and the } \\
& \text { covariances of the skewness } \\
& \text { estimators } \hat{\gamma}_{i} \text {, based upon the size } \\
& \text { and the WLS estimator of the skew } \\
& \text { at each site. }
\end{aligned}
$$

Off-diagonal elements of $\Sigma(\hat{\gamma})$ were estimated by the the cross-correlation of concurrent systematic annual peak flows (eq. 6) and the cf factor (eq. 7), which depends on the record lengths and concurrent record lengths. In calculating the cf factor used to determine the ratio of the number of concurrent peak flows at a pair of sites to the total number of peak flows at both sites, only the systematic records were considered. Thus, any historical floods used in the EMA analysis were not used to calculate the cross-correlation of peak flows or the cf factor. 
This page intentionally left blank. 


\section{Appendix C. Bayesian GLS Regression Diagnostics}

To determine if a model is a good representation of the data and which regression parameters, if any, should be included in a regression model, diagnostic statistics have been developed to evaluate how well a model fits a regional hydrologic data set (Griffis and Stedinger, 2006; Gruber and others, 2008). In this report, the goal was to determine the set of possible explanatory variables that best fit the California peak-discharge data affording the most accurate skew prediction while also keeping the model as simple as possible. This appendix presents the diagnostic statistics for a Bayesian weighted least squares (WLS) or generalized least squares (GLS) analysis, and discusses the specific values obtained for the California regional skew study.

Table C1 presents a Pseudo analysis of variance (Pseudo ANOVA) table for the California regional skew analysis. The table contains regression diagnostics/goodness of fit statistics which are explained below.

In particular, the table provides equations for determining how much of the variation in the observations can be attributed to the regional model, and how much of the residual variation can be attributed to model error and sampling error, respectively. Difficulties arise in determining these quantities. The model errors cannot be resolved because the values of the sampling errors, $\eta_{\mathrm{i}}$, for each site, i, are not known. However, the total sampling error sum of squares can be determined by $\sum_{i=1}^{n} \operatorname{Var}\left[\hat{\gamma}_{i}\right]$. Because there are $n$ equations, the total model error sum of squares due to the model error, $\delta$, for a model with $\mathrm{k}$ parameters is $n \sigma_{\delta}^{2}(\mathrm{k})$. Thus, the residual variation attributed to the sampling error is $\sum_{i=1} \operatorname{Var}\left[\hat{\gamma}_{i}\right]$, and the residual variation attributed to the model error is $n \sigma_{\delta}^{2}(\mathrm{k})$.

For a model with no parameters other than the mean (that is, the constant skew model), the estimated model error variance $\sigma_{\delta}^{2}(0)$ describes all of the anticipated variation in $\gamma_{\mathrm{i}}=\mu+\delta_{\mathrm{i}}$, where $\mu$ is the mean of the estimated at-site sample skews. Thus, the total expected sum of squares variation due to model error, $\delta_{\mathrm{i}}$, and due to sampling error, $\eta_{i}=\hat{\gamma}_{i}-\gamma_{i}$ should equal $n \sigma_{\delta}^{2}(0)+\sum_{i=1}^{n} \operatorname{Var}\left(\hat{\gamma}_{i}\right)$. Therefore, the expected sum of squares attributed to a regional skew model with $\mathrm{k}$ parameters equals $\mathrm{n}\left[\sigma_{\delta}^{2}(0)-\sigma_{\delta}^{2}(\mathrm{k})\right]$, because the sum of the model error variance $n \sigma_{\delta}^{2}(\mathrm{k})$ and the variance explained by the model must sum to $n \sigma_{\delta}^{2}(0)$. Table C1 shows results from models when $\mathrm{k}=0$ and 1 .

Table C1. Pseudo ANOVA table for the Constant model and the NL-Elev model for regional skew in California.

[ANOVA, analysis of variance; NL-Elev model, nonlinear regional skew model; $k$, the number of parameters used in the regional regression; $n$, the number of stations used in the regional skew regression; EVR, error variance ratio; $\mathrm{MBV}^{*}$, misrepresentation of the beta variance; $\mathrm{R}_{\delta}^{2}, \mathrm{Pseudo}_{-} \mathrm{R}_{\delta}^{2}, \%$, percent]

\begin{tabular}{|c|c|c|c|c|c|c|}
\hline \multirow{2}{*}{ Source } & \multicolumn{3}{|c|}{ Degrees of freedom } & \multirow{2}{*}{ Equations } & \multicolumn{2}{|c|}{ Sum of squares } \\
\hline & & Constant & NL-Elev & & Constant & NL-Elev \\
\hline Model & $\mathbf{k}$ & 0 & 1 & $\mathrm{n}\left[\sigma_{\delta}^{2}(0)-\sigma_{\delta}^{2}(\mathrm{k})\right]$ & 0.0 & 15 \\
\hline Model error & $\mathbf{n}-\mathbf{k}-1$ & 157 & 156 & $\mathrm{n} \sigma_{\delta}^{2}(\mathrm{k})$ & 32 & 17 \\
\hline Total & $2 \mathbf{n}-1$ & 315 & 315 & $\mathrm{n} \sigma_{\delta}^{2}(0)+\sum_{i=1}^{\mathrm{n}} \operatorname{Var}\left[\hat{\gamma}_{i}\right]$ & 66 & 66 \\
\hline
\end{tabular}


This division of the variation in the observations is referred to as a Pseudo ANOVA because the contributions of the three sources of error were estimated or constructed, rather than being determined from the computed residual errors and the model predictions, while ignoring the impact of correlation among the sampling errors.

Table C1 compares the Pseudo ANOVA results for the Constant model and the NL-Elev model. Both models have the same sampling error because both use the same set of at-site skew data. Both have sampling error variances greater than their model error variances. However, the model error attributed to the NL-Elev model, $\sigma_{\delta}^{2}(1)$, is slightly more than half of the model error variance attributed to the Constant model, $\sigma_{\delta}^{2}(0)$. This difference is accounted for by the variation in the sample that the NL-Elev model appears to explain. Because the Constant model does not have any explanatory variables, the variation attributed to that model is 0.0 . On the other hand, the NL-Elev model has one explanatory variable, which causes the variation attributed to the model to increase to 15 . This reduces the model error variance from 32 with the Constant model to 17 with the NL-Elev model; thus, adding the nonlinear elevation explanatory variable in the NL-Elev model greatly improves the ability of the model to describe the observed skew coefficients. This impact is described by the Pseudo $\mathrm{R}_{\delta}^{2}$, which in this case is 48 percent because the NL-Elev model explains 48 percent of the estimated variation, $\sigma_{\delta}^{2}(0)$, in the true skew among the sites.

The Pseudo analysis of variance also provides the information needed to evaluate whether or not a sophisticated WLS or GLS analysis is needed to correctly interpret the data. In particular, the error variance ratio (EVR) is a modeling diagnostic used to evaluate whether a simple ordinary least squares (OLS) regression is sufficient or a more sophisticated WLS or GLS analysis is appropriate. EVR is the ratio of the average sampling error variance to the model error variance. Generally, an EVR greater than 20 percent indicates that the sampling variance is not significant when compared to the model error variance, suggesting the need for a WLS or GLS regression analysis. The EVR is calculated as

$$
\mathrm{EVR}=\frac{\mathrm{SS} \text { (sampling error) }}{\mathrm{SS} \text { (model error) }}=\frac{\sum_{\mathrm{i}=1}^{\mathrm{n}} \operatorname{Var}\left(\hat{\gamma}_{\mathrm{i}}\right)}{\mathrm{n} \sigma_{\delta}^{2}(\mathrm{k})},
$$

The EVR was 1.1 for the constant model and 2.1 for the NL-Elev model. The sampling variability of skewness estimators was larger than model error variance of the regional model. Thus, given the variation of record lengths from site-to-site, using a WLS or GLS analysis is important for for evaluating the final precision of the model rather than using a simpler analysis that neglects the sampling error in the at-site skewness estimators.

The misrepresentation of the beta variance $\left(\mathrm{MBV}^{*}\right)$ statistic is used to determine whether a WLS regression is sufficient or a GLS regression is appropriate to determine the precision of the estimated regression parameters (Griffis and Stedinger, 2006). The $\mathrm{MBV}^{*}$ describes the error produced by a WLS regression analysis by evaluating the precision of $\mathrm{b}_{0}^{\mathrm{WLS}}$, which is the estimator of the WLS regression constant, $\beta_{0}^{\text {WLS }}$. The correlation among estimated at-site skews, which is ignored in WLS regression, generally has its greatest impact on the precision of the regression constant term (Stedinger and Tasker, 1985). If the $\mathrm{MBV}^{*}$ is substantially greater than 1 , a GLS error analysis should be used. The MBV* is calculated as

$$
\mathrm{MBV}^{*}=\frac{\operatorname{Var}\left[\mathrm{b}_{0}^{\mathrm{WLS}} \mid \mathrm{GLS} \text { analysis }\right]}{\operatorname{Var}\left[\mathrm{b}_{0}^{\mathrm{WLS}} \mid \mathrm{WLS} \text { analysis }\right]}=\frac{\mathbf{w}^{\top} \boldsymbol{\Lambda} \mathbf{w}}{\sum_{\mathrm{i}=1}^{n} \mathrm{w}_{\mathrm{i}}}
$$

where

$$
\mathrm{w}_{\mathrm{i}}=\frac{1}{\Lambda_{\mathrm{ii}}} .
$$

For the California regional skew study, the MBV* was equal to 16 for the NL-Elev model and 13 for the Constant model. This is a very large value indicating that the crosscorrelation among the skewness estimators has had a major effect on the precision with which the regional average skew coefficient can be estimated; if a WLS precision analysis had been used for the estimated constant parameter in the NL-Elev model, the variance would have been underestimated by a factor of 16 . Thus a WLS analysis would have seriously misrepresented the variance of the constant in the Constant model and in the NL-Elev model of regional skew. This would have caused the variance of prediction to be underestimated given that the sampling error in the constant term in both models was large enough to contribute appreciably to the average variance of prediction.

where

$\mathrm{SS}$ is the sum of squares. 
Publishing support provided by the U.S. Geological Survey

Publishing Network, Sacramento and Tacoma Publishing Service Centers

For more information concerning the research in this report, contact the Director, California Water Science Center

Placer Hall

$6000 \mathrm{~J}$ street

Sacramento, CA 95819

http://ca.water.usgs.gov/ 


\section{$\frac{\mathbb{2}}{3}$}

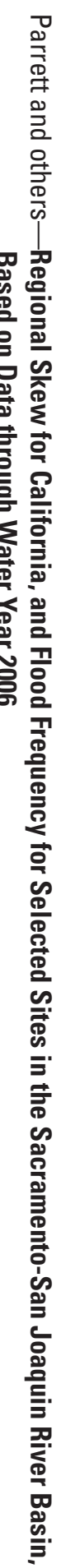

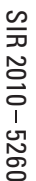

8 Printed on recycled paper 